\title{
CONSUMO E UTILIZAÇÃO DE MILHO, TRIGO E SORGO POR Spodoptera frugiperda (J. E. SMITH, 1797) (LEPIDOPTERA - NOCTUIDAE)
}

\author{
WILSON BADIALI CROCOMO \\ Engenheiro-Agrônomo \\ FACULDADE DE CIENCIAS AGRONÓMICAS \\ UNESP - "CAMPUS"' DE BOTUCATU
}

Oriontador: Dr. JOSE ROBERTO POSTALI PARRA

Tese apresentada à Escola Suporior de Agricultura "Luiz de Queiroz", da Universidade de São Paulo, para obtenção do título de Doutor em Ciências. Área de concentração: Entomologia.

PIRACICABA

Estado de São Paulo - Brasil

Setembro - 1983 
Aos mues pais

AGRADECOO.

I minha esposa

OFEREÇO.

Ao meu bilho

DEDICO. 
iii.

"I L N'Y A PAS DE SCIENCE APPLIQUEE; IL Y A LA SCIENCE ET IL Y A L'APPLI CATION DE LA SCIENCE".

Pasteur 
Ao Dr. José Roberto postali Parra, pela dedicação e esmero com que conduziu a minha formação em Entomologia;

Aos Professores do Departamento de Entomologia da Escola Supe rior de Agricultura "Luiz de Queiroz", pela amizade, apoio e dedicação durante os cursos de Pós-Graduação;

Aos colegas do Departamento de Defesa Fitossanitária da Facul dade de Ciências Agronômicas - UNESP, "Campus" de Botucatu, pelo estimulo e sugestões fornecidàs;

Ao Conselho Nacional de Desenvolvimento Científico e Tecnoló gico (CNPql pelo apoio financeiro;

Aos Funcionários do Departamento de Defesa Fitossanitária da Faculdade de Ciências Agronômicas - UNESP, "Campus" de Bo tucatu, que colaboraram na execução desse trabalho. 


\section{INDICE}

Pảgina

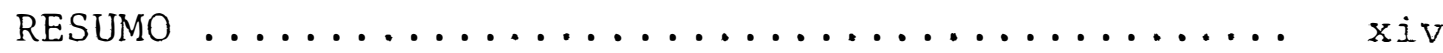

SUMMARY $\ldots \ldots \ldots \ldots \ldots \ldots \ldots \ldots \ldots \ldots \ldots \ldots \ldots \ldots \ldots \ldots \ldots$

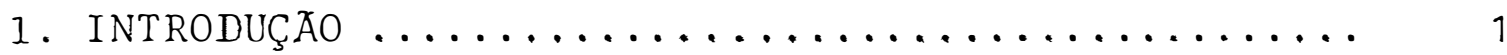

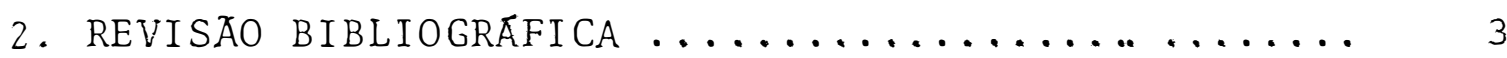

2.1. Interações inseto/planta ............... 3

2.2. Nutrição quantitativa .................... 7

2.3. Custo metabólico ..................... 10

2.4. Spodoptera frugiperda (J.E. Smith, 1797) ... 11

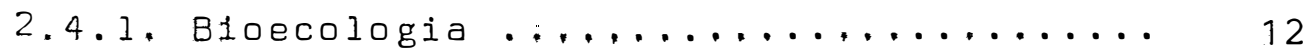

2.5. Consumo e utilização de alimento por Spodopte ra spp.

3. MAterial E MEtodos ........................ 20

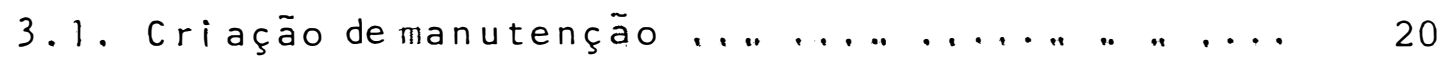

3.2. Manutenção das plantas ................ 21

3.3. Estudo do consumo e utilização de alimentos. 22

3.3.1. Peso de alimento ingerido......... 23

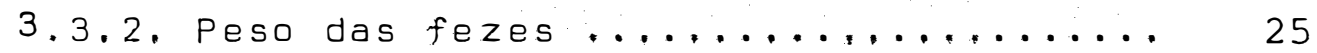

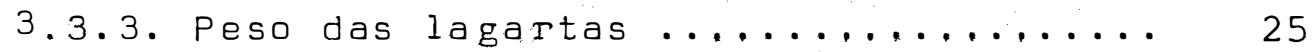

3.3.4. Indices de consumo e utilização...... 26

3.3.5. Determinação da área foliar consumida. 27

3.3.6. Análise estatistica ............. 28

3.4. Desenvolvimento larval .............. 28

3.5. Influência da alimentação da fase larval sobre a seleção hospedeira pelas lagartas des-

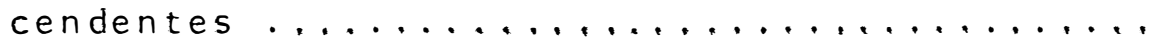

3.6. Influência da alimentação da fase larval sobre a seleção hospedeira pelos adultos .....

(1)

0

1

2

3

5

26

27


4. RESULTADOS E DISCUSSAO ................. 31

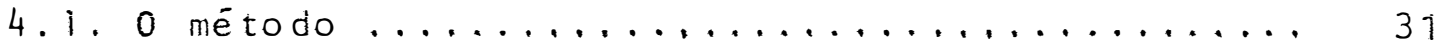

4.2. Paràmetros avaliados ................. 34

4.2 .1 . Consumo de alimento (I) ............ 34

4.2.2. Produção de fezes (F) ............ 37

4.2.3. Ganho de biomassa (B) ............ 37

4.3. Tndices e parâmetros determinados .......... 42

4.3.I. Alimento assimilado $(I-F) \ldots . . . . . .442$

4.3.2. Alimento metabolizado (M) .......... 43

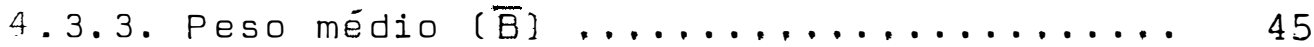

4.3.4. Taxa de consumo relativo (RCR) ...... 45

4.3.5. Taxa metabólica relativa (RMR) ....... 50

4.3.6. Taxa de crescimento relativo (RGR) .... 51

4.3.7. Eficiência de conversão do alimento in-

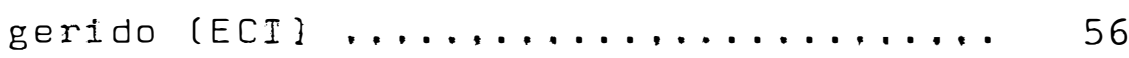

4.3.8. Digestibilidade aproximada (AD) ..... 57

4.3.9. Eficiência de conversão do alimento digerido $(E C D) \ldots \ldots \ldots \ldots \ldots \ldots \ldots \ldots$

4.4. Consumo e utilização dos alimentos.......... 64

4.4.1. Parámetros avalíados ............. 65

4.4.2. Parámetros determinados ............ 65

4.4.3. Indices nutricionais ............. 65

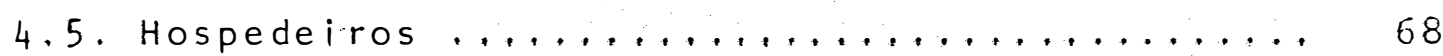

4.6. Consumo de ärea foliar ................ 60

4.7. Desenvolvimento larval .............. 71

4.7 .1 . Duração da fase larval ........... 71

4.7.2. Número de instares .............. 71

4.8. Fase de pupa ..................... 74

4.9. Influência da alimentação da fase larval sobre a seleção hospedeira pelas lagartas descendentes .......................... 77

4.10 Influência da alimentação da fase larval sobre a seleção hospedeira pelos adultos .......... 
vii.

Página

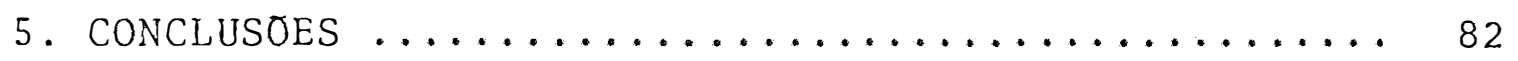

6. LITERATURA CITADA $\ldots \ldots \ldots \ldots \ldots \ldots \ldots \ldots \ldots \ldots$ 
viii.

LISTA DE TABELAS

Tabela

Página

1 Consumo (I) diário médio acumulado (em $\mathrm{mg}$ de matéria seca) de biomassa foliar de milho, tri go e sorgo pelas lagartas de $S$. frugiperda. Temp. $25 \pm^{\circ}{ }^{\circ} \mathrm{C}$, UR $60 \pm_{10} \%$ e fot. $14 \mathrm{~h} . \ldots . . .35$

2 Peso médio diário acumulado (ém mg de matéria seca) das fezes (FL produzidas pelas lagartas de $S$. frugiperda alimentadas com folhas de $\mathrm{mi}$ lho, trigo e sorgo. Temp. $25 \pm 2{ }^{\circ} \mathrm{C}$, UR $60 \pm 10 \%$

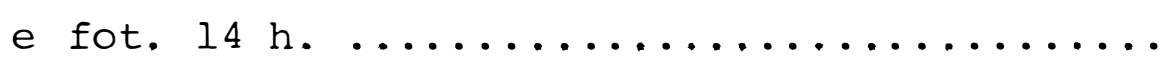

3 Ganho médio diário de peso (B) acumulado (em mg de matéria seca) pelas lagartas de $S$. frugiperda alimentadas com folhas de milho, trigo e sorgo. Temp. $25^{+} 2^{\circ} \mathrm{C}$, UR $60 \pm 10 \%$ e fot. $14 \mathrm{~h}$.

4 Alimento assimilado ( $I-F$ ) (em $\mathrm{mg}$ de matéria seca) pelas lagartas de $S$. frugiperda alimentadas com folhas de milho, trigo e sorgo. Temp. $25 \pm 2{ }^{\circ} \mathrm{C}$, UR $60 \pm 10 \%$ e fot. $14 \mathrm{~h} . \ldots . .$.

5 Alimento metabolizado (M) (em $\mathrm{mg}$ de matéria secal pelas lagartas de $S$, frugiperda alimentadas com folhas de milho, trigo e sorgo. Temp. $25 \pm 2{ }^{\circ} \mathrm{C}$, UR $60 \pm 10 \%$ e fot. $14 \mathrm{~h} . \ldots . .$.

6 Peso médio ( $\bar{B}$ I diário (em mg de matéria seca) das lagartas de $S$. hrugiperda alimentadas com folhas de milho, trigo e sorgo. Temp. $25 \pm 2^{\circ} \mathrm{C}$, 
Taxa de consumo relativo (RCR) das lagartas de $S$. frugiperda alimentadas com folhas de mi lho, trigo e sorgo. Temp, $25 \pm 2{ }^{\circ} \mathrm{C}$, UR $60 \pm 10 \bar{\circ}$ e fot. $14 \mathrm{~h}$.

Taxa metabólica relativa (RMR) das lagartas de $S$. frugiperda alimentadas com folhas de $\mathrm{mi}$ lho, trigo e sorgo. Temp. $25 \pm 2{ }^{\circ} \mathrm{C}$, UR $60 \pm 1 \overline{0 \%}$ e fot, $14 \mathrm{~h}$.

9 Taxa de crescimento relativo (RGR) cias lagartas de $S$. frugiperda alimentadas com folhas de milho, trigo e sorgo. Temp. $25 \pm 2{ }^{\circ} \mathrm{C}$, UR

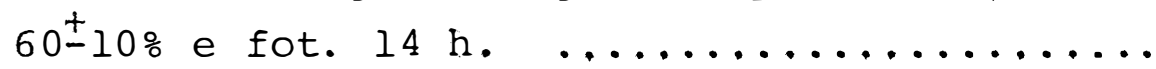

10 Eİiciência de conversão do alimento ingerido (ECI) pelas lagartas de $S$. frugiperda criadas sobre folhas de milho, trigo e sorgo. Temp. $25 \pm 2{ }^{\circ} \mathrm{C}$, UR $60 \pm 10 \%$ e fot. $14 \mathrm{~h} . \ldots \ldots \ldots \ldots \ldots$

11 Digestibilidade aproximada (AD) das folhas de milho, trigo e sorgo para as lagartas de $S$. brugiperda. Temp. $25 \pm 2^{\circ} \mathrm{C}$, UR $60 \pm 10 \%$ e fot. $14 \mathrm{~h}$.

12 Eficiência de conversão do alimento digerido (ECD) pelas lagartas de $S$, frugiperda alimentadas com folhas de milho, trigo e sorgo. Temp. $25 \pm 2{ }^{\circ} \mathrm{C}$, UR $60 \pm 10 \%$ e fot. $14 \mathrm{~h}, \ldots .$. 
13 Comparação das médias dos parâmetros e índices obtidos para lagartas de $S$. frugiperda alimentadas com milho, trigo e sorgo. Temp, $25 \div 2{ }^{\circ} \mathrm{C}$, UR $60 \pm 10 \%$ e fot. $14 \mathrm{~h}$.

14 Relação peso seco/ārea foliar verde do milho, trigo e sorgo e, respectivo consumo em área fo liar e peso seco (I) pelas lagartas de $S$. frugiperda. Temp. $25^{ \pm} 2^{\circ} \mathrm{C}$, UR $60 \pm 10 \%$ e fot. $14 \mathrm{~h}$.

15 Duração média (em diasl de cada um dos ínstares e de toda a fase larval de $S$. frugiperda alimentada com folhas de milho, trigo e sorgo. Temp. $25 \pm^{\circ}{ }^{\circ} \mathrm{C}$, UR $60 \pm 10 \%$ e fot. $14 \mathrm{~h} . \ldots \ldots \ldots$

16 Largura média da cápsula cefálica, razão de crescimento e decremento da razão de crescimento de $S$. frugiperda alimentada com folhas de milho, trigo ou sorgo. Temp. $25 \pm 2{ }^{\circ} \mathrm{C}$, uR $60 \pm$

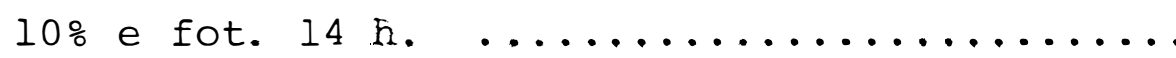

17 Peso de pupas e viabilidade pupal por sexo, de $S$. frugiperda criada em milho, trigo e sorgo. Temp. $25 \pm 2{ }^{\circ} \mathrm{C}$, UR $60 \pm 10 \%$ e fot. $14 \mathrm{~h} . \ldots \ldots \ldots$

18 Seleção do alimento por lagartas de $S$. frugiperda descendentes de indivíduos criados em milho, trigo e sorgo. Term. $25^{ \pm} 2^{\circ} \mathrm{C}$, US $60^{ \pm} 10 \%$ e fot. $14 \mathrm{~h} . \ldots$.

19 Oviposição de $S$. Kugiperda proveniente de la gartas alimentadas com milho, trigo e sorgo. Temp. $25 \pm 2^{\circ} \mathrm{C}$, UR $60 \pm 10 \%$ e fot. $14 \mathrm{~h}$. 


\section{LISTA DE FIGURAS}

Figura

1 Coeficiente de variação (CV) das médias de con sumo diário acumulado das lagartas de $S$. frugi perda criadas em milho, trigo e sorgo. Temp. $25^{ \pm} 2 \circ \mathrm{C}$, UR $60 \pm 10 \%$ e fot. $14 \mathrm{~h} . \ldots \ldots \ldots \ldots$

2 Consumo diário médio acumulado (em mg de matéria secal de biomassa foliar (I) de milho, tri go e sorgo pelas lagartas de $S$, frugiperda. Temp. $25 \pm 2{ }^{\circ} \mathrm{C}$, UR $60 \pm 10 \%$ e fot. $14 \mathrm{~h}$. (Médias -

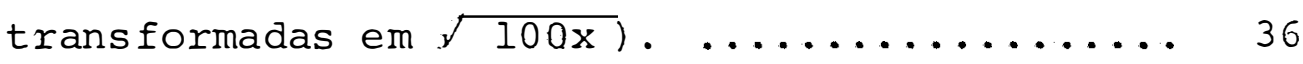

3 Peso diário médio acumulado (em $\mathrm{mg}$ de matéria secal das fezes (FL produzidas pelas lagartas de $S$, frugiperda alimentadas com folhas de mi1ho, trigo e sorgo. Temp. $25 \pm 2{ }^{\circ} \mathrm{C}$, UR $60 \pm 10 \% \mathrm{e}$ fot. $14 \mathrm{~h}$. (Médias transformadas em $\sqrt{100 \mathrm{x}}$ )..

4 Ganho diário de biomassa (B) (em mg de matéria secal pelas lagartas de $S$. frugiperda alimenta das com folhas de milho, trigo e sorgo. Temp. $25 \pm 2^{\circ} \mathrm{C}$, uR $60 \pm 10 \%$ e fot. $14 \mathrm{~h}$. (Médias trans-

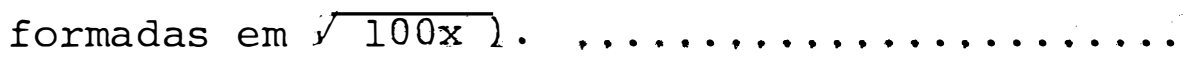

5 Alimento assimilado (I-F) (em mg de matéria se ca) pelas lagartas de $S$. frugiperda alimentadas com folhas de milho, trigo e sorgo. Temp. $25 \pm 2{ }^{\circ} \mathrm{C}$, UR $60 \pm 10 \% \mathrm{e}$ fot. $14 \mathrm{~h}$.

6 Alimento metabolizado (ML (em $\mathrm{mg}$ de matéria se cal pelas lagartas de $S$. frugiperda alimenta- 
xii.

Figura

Página

6 das com folhas de milho, trigo e sorgo. Temp. $25 \pm 2^{\circ} \mathrm{C}$, UR $60 \pm 10 \%$ e fot. $14 \mathrm{~h}$.

7 Peso médio diário ( $\bar{B})$ (em mg de matéria seca) das lagartas de $S$, irugiperda alimentadas com folhas de milho, trigo e sorgo. Temp. $25 \pm 2{ }^{\circ} \mathrm{C}$, UR $60 \pm 10 \%$ e fot. $14 \mathrm{~h}$.

8 Taxa de consumo relativo ( $R C R$ ) das lagartas de S. Grugiperda alimentadas com folhas ce milho, trigo e sorgo. Temp. $25 \pm 2^{\circ} \mathrm{C}$, UR $60 \pm 10 \%$ e fot. $14 \mathrm{~h}$.

9 Taxa metabólica relativa (RMR) das lagartas de S. frugiperda alimentadas com folhas de milho, trigo e sorgo. Temp. $25 \pm^{\circ} \mathrm{C}$, UR $60 \pm 10 \%$ e fot. $14 \mathrm{~h}$.

10 Taxa de crescimento relativo (RGR) das lagartas de $S$. Hrugiperda alimentadas com folhas de milho, trigo e sorgo. Temp. $25 \pm 2{ }^{\circ} \mathrm{C}$, UR $60 \pm 10 \%$ e fot. $14 \mathrm{~h}$.

11 Eficiência de conversão do alimento ingerido (ECIL pelas lagartas de $S$. frugiperda alimenta das com folhas de milho, trigo e sorgo. Temp. $25 \pm 2{ }^{\circ} \mathrm{C}$, UR $60 \pm 10 \% \mathrm{e}$ fot. $14 \mathrm{~h}$.

12 Digestibilidade aproximada (AD) das folhas de milho, trigo e sorgo para as lagartas de $S$. frugiperda. Temp. $25 \pm 2{ }^{\circ} \mathrm{C}$, UR $60 \pm 10 \%$ e fot. 14

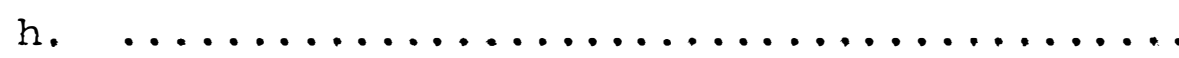


13 Eficiência de conversão do alimento digerido (ECD) pelas lagartas de $S$. frugiperda alimenta das com folhas de milho, trigo e sorgo. Temp. $25 \pm 2{ }^{\circ} \mathrm{C}$, UR $60 \pm 10 \%$ e fot. $14 \mathrm{~h} . \ldots \ldots \ldots \ldots$

14 Médias dos parâmetros e índices nutricionais obtidos para as lagartas de $S$. frugiperda alimentadas com milho (M), trigo. ( $T$ ) e sorgo (S). Temp. $25 \pm 2^{\circ} \mathrm{C}$, UR $60 \pm 10 \%$ e fot. $14 \mathrm{~h}, \ldots \ldots$

15 Largura da cápsula cefálica, número de ínstares e duração de cada ínstar larval de $S$. frugiperda criada sobre milho, trigo e sorgo. Temp. $25 \pm 2^{\circ} \mathrm{C}$, UR $60 \pm 10 \%$ e fot. $14, \mathrm{~h} . \ldots . . .73$

16 Frequêencia de duração do período pupal de machos e fêmeas de $S$. frugiperda criadas com milho, trigo e sorgo. Temp. $25 \pm 2{ }^{\circ} \mathrm{C}$, UR $60 \pm 10 \% \mathrm{e}$

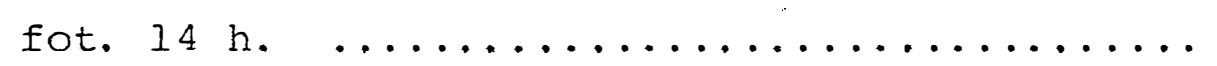




\section{CONSUMO E UTILIZACÃO DE MILHO, TRIGO E SORGO \\ POR spodoptera trugiperda (J.E. SMITH, 1797)}

(LEPIDOPTERA-NOCTUIDAE)

AUTOR: WILSON BADIALI CROCOMO

ORIENTADOR: DR， JOSÉ ROBERTO POSTALI PARRA

RESUMO

Os indices de consumo e utilização de alimentos, assim como alguns parâmetros biológicos, foram determina dos para as lagartas de spodoptera frugiperda (J.E. Smith, 1797) alimentadas com folhas de milho 'HMD 7974', trigo 'Alonda' e sorgo sacarino 'BR-501', com o objetivo de se conhecer o comportamento alimentar do inseto e algumas de suas relações com a planta hospedeira. O experimento foi instalado com ovos obtidos de insetos criados em dieta artificial. O delineamento experimental foi inteiramente casualizado com 3 tratamentos, 10 repetições e parcelas de 10 insetos, sendo os dados obtidos em peso seco. Os dados nutricionais diários demonstraram que as lagartas apresentaram a capacidade de compensar as dificuldades de consumo e utilização dos diferentes hospedeiros para manter a performance de desenvolvimento. Os dados refe.rentes a toda fase larval demonstraram que as lagartas criadas em milho apresentaram as taxas de consumo (RCR) e metabólica (RMR) maiores e as eficiências de corversão do alimento ingerido (ECI) e do digerido (ECD) menores. As folhas de milho e de sorgo apresentaram uma digestibilidade aproximada (AD) semelhante e inferior às das folhas de trigo, respectiva mente. As lagartas mantidas em trigo apresentaram as menores 
taxas de consumo e metabólica (RCR e RMR) e as maiores eficiēncias de conversão do alimento ingerido e do digerido (ECI e ECD). O ganho de biomassa (B) foi semelhante nas três gramí neas estudadas, sendo, o custo metabólico maior para as lagar tas que se alimentaram de folhas de milho. Assim, o trigo foi o alimento que apresentou as melhores caracteristicas nutricionais para o inseto, embora o milho tenha sido o hospedeiro preferido pelas lagartas recém-eclodidas. O alimento não interferiu no número de instares, que foi constante e igual a.6. Porém, a duração, tanto da fase larval como da fase pupal, foi um dia maior para as lagartas criadas em milho, as quais também apresentaram uma viabilidade e peso pupal significativa mente maior. Independentemente do alimento, a emergência das fêmeas foi anterior a dos machos. O alimento ingerido afetou a preferência alimentar das lagartas na geração seguinte. o consumo de área foliar foi maior no milho, devido a menor por centagem de matéria seca deste vegetal. 
CONSUIPTION AND UTILIZATION OF CORN, WHEAT AND SORGHU:A

BY spodoptera frugiperda (J.E. SMITH, 1797)

(LEPIDOPTERA-NOCTUIDAE)

\section{AUTHOR: WILSON BADIALI CROCOMO}

ADVISER: DR, JOSÉ ROBERTO POSTALI PARRA

SUMMARY

The food intake and utilization, as well as some biological parameters, were determined for larvae of Spo doptera frugiperda (J.E. Smith, 1797) fed on 'HMD-7974' corn, 'Alonda' wheat and 'BR-501' sweet sorghum leaves. The objective of this study was to understand the feeding behavior of this insect as well as some of its relationships with the host plant. The experiment was carried out using eggs of insects reared on an artificial diet. An entirely randomized design, with three treatments, 10 replications, and plots with 10 insects was utilized. The data were obtained in dry weight by the standard gravimetric technique. The daily data showed that the caterpillars were able to compensate the consumption and utilization difficulties of the different hosts to maintain the development performance. The data on the entire larval phase showed that the caterpillars reared on com had the highest relative consumption rate ( $R C R$ ) and relative metabolic rate (RMC) and the lowest efficiency of conversion of ingested food (ECI) and digested food (ECD). The approximate digestibility (AD) for corn and sorghum leaves was similar, but lower than that for wheat leaves. The caterpillars reared on wheat leaves showed the lowest consumption and metabolic rates ( $R C R$ and 
RMR) and the highest efficiency of conversion of ingested food (ECI and ECD). The biomass gain (B) was similar for the three hosts tested. The highest metabolic cost was that for larvae fed on corn leaves. Wheat was shown to have the best nutritional characteristics for this insect, even though corn was the recently hatched larvae's preferred host. Food did not interfere with the number of instars, which remained constant and equal to 6 . The duration of the larval and pupal phases was one day longer for caterpillars reared corn. The latter also showed a significantly higher viability and weight. Female emergence occurried earlier than for males in all hosts studied. The food ingested affected the next generation's food preference of larvae in the following generation. Foliar area consumption was higher for corn, due to the lowest dry matter per centage this host. 
1. INTRODUÇÃO

- grande sucesso que os inseticidas organo-sin téticos obtiveram nas três últimas décadas vem sendo abalado recentemente, devido aos śerios riscos causados à saúde dos agricultores e da população consumidora de produtos agrícolas, e aos efeitos deletérios sobre a qualidade do ambiente; isto tudo tem sido agravado pela diminuição dos lucros agrícolas em consequiência do uso crescente de defensivos, cada vez mais tóxicos, e caros, para controlar pragas que se tornam potencialmente mais danosas. Apesar disso, a facilidade de uso des tes defensivos químicos e a grande eficiência na solução a curto prazo, de inúmeros problemas de pragas, têm desviado a atenção da maioria dos pesquisadores da necessidade de estudos básicos, que conduzam ao desenvolvimento de outros métodos de controle de insetos.

- Em se tratando de insetos fitófagos, que em ge ral são extremamente dependentes da planta hospedeira, não há dúvida de que muitas soluções podem ser obtidas através do perfeito entendimento das relações inseto/planta.

As relações inseto/planta, que atualmente podem ser constatadas, são o resultado de um longo processo coe volutivo em que as plantas desenvolveram características físicas e químicas, às quais os insetos foram se adaptando, atra 
vês de respostas fisiológicas e de comportamento. As substâncias químicas envolvidas nesse processo (aleloquímicos) " têm um papel de relevante importància na resistência de plantas a insetos, principalmente no que se refere à antixenose e antibiose.

De acordo com JONES et al. (1981), o entendimen to dos mecanismos químicos envolvidos na resistência, preferência e seleção da planta hospedeira pode ser obtido através do conhecimento do comportamento alimentar do inseto.

Dessa forma, procurou-se estudar o consumo e a utilização de três gramíneas (milho, sorgo e trigo) pela lagarta-do-cartucho-do-milho spodoptera frugiperda (J.E. Smith, 1797), com o objetivo de desenvolver metodologia e verificar possíveis diferenças de comportamento alimentar que possam ser utilizadas em futuros estudos sobre as relações inseto/ planta.

Este trabalho foi realizado utilizando $S$, frugiperda, por se tratar de um inseto capaz de se alimentar de diferentes espécies de gramíneas, além de ser importante praga agrícola,com uma metodologia de criação em laboratório bem conhecida. 
2. REVISÃO BIBLIOGRĀFICA

2.1. Interaçöes inseto/planta

BRUES (1946) estimou que mais da metade das es pécies de insetos conhecidas são dependentes da planta hospedeira e, embora possam se alimentar de qualquer parte da plan ta, não há dúvida de que as folhas verdes são o seu principal alimento, de tal forma que o dano causado ãs folhas é um dos mais importantes problemas do entomologista.

FRAENKEL (1953) considerou que, sendo as folhas verdes o principal alimento dos insetos e, em muitos casos, o único, é óbvio que elas contenham todos os nutrientes exigidos. Porém, explicou a especificidade hospedeira de algumás espécies de insetos fitófagos de duas maneiras diferentes, ou na combinação delas. No primeiro caso, admitiu que os insetos diferem em suas necessidades nutricionais bāsicas e as plantas diferem em composição química. Assim, os insetos seriam específicos àquelas plantas onde encontrassem suas necessidades dietéticas. No segundo caso, admitiu que as necessidades nutricionais bāsicas são as mesmas para todos os insetos fitó fagos e podem ser igualmente satisfeitas pelas folhas verdes. Nesse caso, a especificidade hospedeira seria determinada pela presença ou ausência de substâncias tais como glucosídeos, saponinas, tanino, alcalóides ou óleos essenciais, que são 
características para diferentes ordens ou famílias de plantas $e$, até onde conhecido, não têm valor nutricional para os inse tos. Segundo DETHIER (1947), a função dessas substâncias seria atraente ou repelente.

FRAENKEL (1953) examinou os vários constituintes químicos das folhas e comparou-os com as necessidades nutricionais dos insetos, concluindo que a composição química das folhas de diferentes plantas, assim como as necessidades nutricionais dos insetos diferem relativamente pouco entre si. E atribuiu a especificidade hospedeira à presença de substân cias químicas que conferem estímulo aos ōrgãos sensoriais do olfato e gustação.

PAINTER (1958), analisando a resistência de plantas a insetos por antibiose, considerou as alterações no tamanho e fecundidade, apresentadas por insetos alimentados sobre plantas resistentes, como resultado de distūrbios nutri cionais. E relatou que tais distūrbios nutricionais podem en volver diferenças qualitativas e quantitativas no alimento, porém não descartou a possibilidade de serem causadas pela presença de antivitaminas e antimetabólitos.

PAINTER (1958) também analisou o trabalho de FRAENKEL (1953) e considerou possível que todas as plantas se jam nutricionalmente satisfatórias. Porém, criticou o fato de FRAENKEL (1953) ter considerado o valor nutricional das folhas inteiras, uma vez que aificilmente um inseto come uma fo lha inteira, tais como foram analisadas. E citou várias espé cies que confinam seu ataque a um determinado tecido como floema, epiderme, etc., sugerindo que esses tecidos fossem analisados separadamente â procura de diferenças nutricionais.

BECK (1965) observou que os insetos fitófagos de comportamento relativamente polífago apresentam um crescimento mais rāpido, uma vida mais longa e melhor capacidade re produtiva sobre algumas espécies de plantas do que em outras. 
Estudos quantitativos da razão de ingestão, da eficiência de digestão e conversão do alimento em biomassa, têm mostrado di ferenças na viabilidade de diferentes plantas como hospedeiras, mas sem explicar o papel das necessidades nutricionais dos insetos nas suas relações com a planta hospedeira.

REESE (1977) consicerou que as substâncias bio químicas de plantas, conforme seus efeitos sobre os insetos, podem ser divididas em nutrientes e não nutrientes. Acreditava-se que os nutrientes eram a base química para a especifici dade hospedeira. Entretanto, constatou-se que a maioria das espécies de insetos não difere grandemente em suas necessidades qualitativas de nutrientes $e$, as plantas hospedeiras satisfazem as suas necessidades nutricionais. Assim, parece que os nutrientes desempenham um papel de menor importância na especificidade hospedeira. Por outro lado, os não nutrientes podem ser fatores extremamente importantes na resistência da planta, pois afetam o crescimento e a fisiologia nutricional dos insetos, assim como podem interagir com os nutrientes.

Esses não nutrientes, que são substâncias prodụ zidas por um organismo de uma espécie e afetam o crescimento, saúde, comportamento e biologia da população de outra espécie, foram denominados aleloquímicos por WHITTAKER (1970).

Segundo KOGAN (1976), esses compostos, atuando como aleloquímicos, podem provocar respostas positivas ou negativas nos insetos. Quando as respostas são negativas ou favoráveis à planta, denominam-se alomônios. Quando as respostas são positivas ou desfavoráveis â planta denominam-se cairomônios. O fato de uma substância atuar como alomônio ou cai romônio é o resultado de uma evolução adaptativa que favoreça a planta ou o inseto, respectivamente. Esse autor também considerou que é incontestável o papel alelopático dos produtos naturais de plantas nas interacooes planta/planta, planta/doen ça e planta/herbívoro. 
Conforme EDWARDS e WRATTEN (1980), as plantas são muito ricas em substâncias químicas aparentemente não relacionadas diretamente com os processos metabólicos normais de fotossíntese, respiração e crescimento. Estas substâncias químicas, denominadas secundárias, também ocorrem em animais. Porém, mais de $80 \%$ dos produtos naturais conhecidos são de origem vegetal. SCHOONHOVEN (1982) referiu-se ã cerca de 10.000 metabólitos secundārios de plantas quimicamente defini dos e, estimou o número total superior a 400.000 .

Segundo KOGAN (1976), os insetos vivem em um ambiente permeado de substāncias químicas de todo tipo. Essas substâncias químicas originárias das plantas, incluindo aquelas que são liberadas no ar e no solo, afetam o inseto antes ou exatamente quando entram em contato com a planta. Outras substâncias estão contidas em tecidos da planta e atuam sobre o inseto somente depois de liberadas pela destruição do tecido. Essas substāncias promovem reações fisiológicas e de comportamento que afetam também os processos ecológicos. De acor do com esse autor, têm surgido muitas evidēncias da atividade alelopática dos produtos das plantas nas interações inseto/ /planta, sendo que muitos deles foram correlacionados com determinadas fases do processo de seleção hospedeira.

Para KOGAN (1975), o processo de seleção hospe deira em insetos fitófagos é uma cadeia de eventós, constituí da por estímulos da planta e respostas do inseto, na qual cada passo possibilita a realização do seguinte. Esta cadeia de eventos consta dos seguintes passos: 1) encontro do habitat do hospedeiro; 2) encontro do hospedeiro; 3) reconhecimento do hospedeiro; 4) aceitação do hospedeiro e 5) viabilidade do hos pedeiro. Os compostos do metabolismo secundário exudados das camadas mais externas do tecido e que se distribuem no ambien 
te em torno da planta, geram um estímulo olfativo, que prevalece no encontro e reconhecimento do hospedeiro. O ambiente interno da planta é formado de uma complexa mistura de compos tos, alguns com valor nutricional, alguns atuando como excitantes ou inibidores de alimentação, alguns tóxicos e, provavelmente um grande número de compostos inertes.

EDWARDS e WRATTEN (1980) relataram que pequenas mudanças no material que a planta fornece ao herbívoro po dem afetar fundamentalmente sua performance. Também considera ram a existência de um potencial evidente, mas ainda não completamente compreendido, para avaliar bioquimicamente a resis tência de plantas a insetos. Segundo esses autores, seria pos sível selecionar novas linhagens de plantas através dos "níveis de uma ou mais substâncias químicas facilmente dosáveis.

SCHOONHOVEN (19.82) considerou que a idéia de utilizar os compostos produzidos pela própria planta, no controle de pragas, tem se desenvolvido muito lentamente. Há qua se meio século descobriu-se que as folhas da árvore Melia aze darach contêm substâncias com forte ação inibidora da ativida de alimentar do acridídeo Schistocerca gregaria (Valkonsky, 1937, citacio por esse autor!. Entretanto, revisões recentes mostraram que essa descoberta ainda não foi estudada com o objetivo de ser utilizada em métodos de controle de prạ gas (Wasthen, 1979; Schmutterer et al., 1981, citados pelo mesmo autor).

2. 2. Nutrição quantitativa

A nutrição quantitativa consiste na avaliação das quantidades de alimento consumido, digerido, assimilado, excretado, metabolizado e convertido em biomassa. A análise desses parâmetros revela como o organismo responde a diferentes alimentos e quais componentes do alimento exercem o maior 
efeito sobre o crescimento. Os estudos de nutrição quantitati va de insetos, também têm auxiliado bastante no esclarecimento dos processos envolvidos na preferência, seleção hospedeiro e antibiose.

WALDBAUER (1968) relatou que foram desenvolvidas muitas formas de medir a ingestão e utilização de alimen.tos por insetos consumindo dietas naturais. Esse tipo de informação, de grande utilidade, seria, em alguns casos, de difícil interpretação, devido à falta de padronização e da variação na precisão dos métodos de avaliação, resultantes da confusão gerada pela aplicação de índices derivados da nutrição de vertebrados. Assim, esse pesquisador revisou o assunto e propōs uma metodologia e uma padronização de índices que per mitisse a comparação dos diferentes trabalhos realizados.

BHATTACHARYA e PANT (1976), em revisão sobre as relações inseto/planta, ressaltaram a importāncia dos índi ces na análise do comportamento alimentar dos insetos fitófagos.

SCRIBER e SLANSKY Jr. (1981) revisaram e atualizaram a bibliografia sobre o assunto e propuseram algumas alterações na terminologia estabelecida por WALDBAUER (1968).

Conforme REESE (1971), os insetos fitófagos não se desenvolvem igualmente bem em todas as plantas hospedeiras ou tecidos de plantas, mesmo quando não há qualquer bar reira aparente à sua alimentação. As diferenças no desenvolví mento do inseto são muito grandes para serem atribuídas à diferenças no conteūdo de nutrientes, mesmo entre diferentes te cidos, como proposto por PAINTER (1958). Segundo esse mesmo autor, os aleloquímicos, caracteristicos de várias espécies de plantas, exercem forte influência sobre o crescimento e de senvolvimento dos insetos, pois podem interagir com os nutrientes essenciais do alimento. Muitos dos efeitos deletérios ou crônicos das plantas podem ser devidos a várias interações entre aleloquímicos e nutrientes. Assim, a inibição do 
crescimento pode ser devida à inibição da assimilação, ou da e ficiência de conversão do alimento assimilado ou da combinação de ambos. A inibição de cada um desses processos, inibirá a eficiência de con versão do alimento ingerido. Tambérn, observou que os índices nutricio-. nais, em especial a digestibilidade aproximada ( $A D)$, a eficiência de con versão do alimento digerido (ECD) e a eficiência de conversão do alimen to ingerido (ECI) variam grandernente entre insetos alimentados com diferentes plantas hospedeiras e não-hospedeiras. Considerou também que esses indices são de grande utilidade na identificação de processos fị siológicos influenciados por aleloquímicos de plantas, especialmente quando é possivel testar o produto químico isolado sob condições experimentai's definidas.

Conforme KOGAN e PARRA (1981), os estudos utilizando os indices de consumo e utilização de alimentos por insetos como critério analítico, são encontrados no campo da nutrição, comunidade ecológica, comportamento, resistência de plantas a insetos e controle de pragas. Esse campo de estudo situa-se, portanto, no limite entre a fisiologia alimentar e o comportamento de seleção hospedeira. A maior parte dos tra balhos realizados com os índices de consumo e utilização de alimentos, empregou-os como indicador da adequabilidade de dietas a inse tos (Waldbauer, 1964; Kogan, 1972; Latheef e Harcourt, 1972; Beker e Schwalde, 1975; Bailey, 1976; Bhat e Bhattacharya, 1978; Ram e Bhattacharya, 1978) (citados por esses autores). Tais ín dices também tên sido empregados no estudo das relações entre a quantidade de alimento ingerido e a sua conversão em substância corpórea. Isso tem revelado que os componentes específicos da dieta, tais como a ăgua, nutrientes inorgânicos e orgânicos e metabólitós secundários de plantas podem afetar profundamente o comportamento e a fisiologia dos insetos. Esses índices também têm sido empregados em trabalhos sobre comunidades ecológícas para avaliar a aptidão de complexos de espécies fitófagas em relação às plantas hospedeiras. E, na ārea de Entomologia Agrícola, a anālise da ingestão e utilização de alimentos tem sido feita em estudos que visam investigar os mecanismos de resistência de plantas a insetos e classifi- 
car os níveis de resistência.

Segundo SCRIBER e SLANSKY JR. (1981), a perfor mance fisiológica de muitos artrópodos é determinada em grande parte pela qualidade do alimento. Dessa forma, um modelo de crescimento populacional preciso deve incluir, em adição aos dados usuais, informações sobre os efeitos da qualidade dos alimentos e outros fatores ambientais sobre a série de es pécies hospedeiras utilizadas. Por outro lado, consideraram que o estudo da nutrição quantitativa é insuficiente para esclarecer os mecanismos de resistẽncia"da planta a insetos, sendo necessários estudos fisiológicos e químicos. Esses auto res, reafirmaram as mesmas observações de REESE (1977) com re lação aos efeitos dos aleloquímicos e suas possíveis interações com nutrientes sobre a performance biológica dos insetos.

SLANSKY Jr. e SCRIBER (1982) apresentaram uma revisão sobre os índices de consumo e utilização de alimentos por insetos e listaram os principais trabalhos realizados sobre esse tema.

\subsection{Cus to metabólico}

O fato das plantas não conterem somente nutrientes, mas também aleloquímicos, que provavelmente atuam como um sistema de defesa contra herbívoros, teoria expressa por muitos autores desde FRAENKEL (1959l, implica que as espécies de insetos que "adotam" uma planta como fonte de alimento tenham que neutralizar o efeito tóxico dos seus aleloquímicos.

Segundo SCHOONHOVEN e MEERMAN (1978), essa bar reira é de considerável importāncia, uma vez que as interações na natureza são longas e intensas. Assim, um inseto bem sucedido em transpor essa barreira química, provavelmente tem que "pagar" continuamente por isso. E evidente que a energia gas- 
ta na desintoxicação dos aleloquímicos presentes em plantas não hospedeiras é bastante elevada. Porém, os insetos utilizam quantidade relativamente grande de energia para neutralizar os aleloquímicos específicos de suas plantas hospedeiras. Segundo esses mesmos autores, é essencial conhecer o custo me tabólico da neutralização dos aleloquímicos da planta hospedeira para compreender certos problemas fisiológicos do desen volvimento das relações inseto/hospedeiro, considerando que a seleção do alimento, quando baseada na experiēncia prévia do indivíduo, está correlacionada com sua capacidade de utilizar o alimento. Assim, o estado fisiológico do inseto dirige seu comportamento alimentar, de tal maneira que a seleção pode ser combinação da plasticidade do comportamento de seleção e da $\underline{e}$ ficiēncia do processo digestivo, sendo a ligação entre ambos inteiramente genética.

\subsection{Spodoptera frugiperda (J.E. Smith, 1797)}

Segundo METCALF e FLINT (1965), S. frugiperda é um inseto que pode ser encontrado no continente Americano desde o México até a América do Sul. Sua presença também foi registrada por MERTEL et al. (1980) e MALAUSA e MARTAL (1981), em várias regiões da França.

SILVA et al. (1968) apresentaram um lista bastante extensa de plantas hospedeiras pertencentes a diferentes familias, de tal forma que essa espécie pode ser classifi cada como polifaga. Entretanto, LUCCHINI (1977) salientou sua marcante preferēncia pelas gramíneas como milho, sorgo, arroz, cana-de-açúcar e pastagens. SIFUENTES (1967), comparando a re sistēncia do milho e sorgo a esse inseto, constatou marcante preferēncia de oviposição e alimentação por plantas de milho. LARA (1979) observou que é inútil tentar a realização de testes com $S$. frugiperda em variedades de sorgo, quando existe cultivo de milho nas adjacēncias do experimento, tal a prefe- 
rência do inseto por essa cultura. Sugeriu também que ao se realizar experimentos com outras pragas na cultura do sorgo, onde for necessário evitar a influência do ataque da lagarta-do-cartucho, é suficiente plantar algumas linhas de milho ao redor do campo experimental.

Os danos de $S$. frugiperda consistem no ataque às folhas da planta, raspando-as durante os 10 e 29 ínstares larvais. A partir do 3 ínstar a lagarta penetra no cartucho do milho, perfurando as folhas (LEIDERMAN e SAUER, 1953). Segundo CARVALHO (1970), seus danos chegam a causar reduções de até 34\% à produção de milho. CRUZ e TURPIN (1982) constataram que o dano é variável em função da idade da planta e concluíram que a redução mãxima da produção é atingida quando a plan ta apresenta 8-10 folhas, ou seja, cerca de 40 dias após o plantio.

\subsubsection{Bioecologia}

CHITTENDEN (1901l fez uma das primeiras revisões sobre $S$. frugiperda abordando nomenclatura, histórico, distribuição geográfica, plantas hospedeiras, inimigos naturais e medidas de combate a esse inseto.

DEW (1913L estudou a biologia dessa praga em laboratório e campo, observando que as mariposas colocam cerca de 160 a 170 ovos, durante a noite, sobre folhas de gramíneas, algodoeiro e outros vegetais. Constatou um período de incubação de 3 dias em médía; o perf́odo larval foi de 14 dias e as lagartas apresentaram 6 ínstares, transformando-se em pu pa no solo. O período pupal foi de 10 dias e o ciclo total de 30 dias à temperatura média de $25^{\circ} \mathrm{C}$.

SMITH (1921). observou, sobre culturas de aveia, trigo e alfafa, um período de pré-oviposição de 3 dias e, relatou que as posturas eram feitas em massas na página inferior 
das folhas. Encontrou um período larval de 23 dias e pupal de 7 dias, em média.

LUNGIBILL (1928) verificou que o nümero médio de ovos por fêmea é de 1393, colocados entre l a 13 posturas, com cerca de 243 ovos cada uma. Observou um período de incubá ção de 2 dias à $26,7^{\circ} \mathrm{C}$ e de 4 dias à $20,6^{\circ} \mathrm{C}$. O período larval foi de 12,1 a 29,7 dias e o pupal de 9 a 27 dias dependendo das condiçōes climáticas. Os adultos viveram 13,3 dias quando alimentados com solução de mel ou açücar em água e 3,35 dias quando não alimentados.

HYNES (1942) criou o inseto em laboratório, ve rificando que as posturas são feitas na página superior das folhas do milho. Obteve um período de incubação de cerca de 2 a 3 dias, um período larval de 14 a 25 dias, e constatou a ocorrência de 6 a 7 ínstares. Verificou também um período prépupal de 2 a 3 dias e um período pupal de 8 a 11 dias, o qual se passa no solo entre 2,5 a $7,5 \mathrm{~cm}$ de profundidade.

FONSECA (1943) relatou que as posturas são fei tas à noite, na página inferior das folhas, em grupos de 60 a 100 ovos dispostos em 2 ou 3 camadas superpostas. Obteve um período larval de 20 a 30 dias e a pupação ocorreu a 1 cm abai xo da superfície do solo.

BERTELS e ROCHA (1950l observaram um período de incubação de até 10 dias em função da temperatura. o perío do larval foi de 3 a 4 semanas. Verificaram também, que a pupação ocorre no solo quando este é arenoso ou na própria plan ta quando é argiloso. A duração da fase pupal foi de 2 semanas.

FENTON (1952) observou que as posturas são rea lizadas à noite, em massas de 40 a 500 ovos. Obteve uma duração média da fase larval de 10,9 dias e da fase pupal de 9,6 dias.

LEIDERMAN e SAUER (1953) verificaram, em condi 
ções de laboratório, uma duração de 25 dias para a fase larval e 19 dias para a fase pupal.

MENSCHOY (1956) constatou que a população de S. frugiperda aumenta bastante nos anos secos. Obteve uma duração da fase larval de 21 a 28 dias e observou que cada fêmea coloca até 1000 ovos.

ETCHEVERRY (1957), trabalhando com S. frugiper da em diferentes temperaturas, verificou que a cópula ocorre à noite no 2 : dia após a emergência. Obteve um período de préoviposição de 7 dias à $15^{\circ} \mathrm{C}$ e 3 dias à $22^{\circ} \mathrm{C}$; o período larval foi de 30 a 35 dias à $15^{\circ} \mathrm{C}$ e de 12 a 24 dias ã $22^{\circ} \mathrm{C}$.

ESTRADA (1960l obteve duração de 11 dias para

a fase larval, 8 dias para a fase pupal e 4 dias para a longe vidade.

MARQUEZ et al. (1963-1964) verificaram que o tempo de incubação é dependente da temperatura e que o ciclo de vida foi menor para insetos criados sobre dieta artificial à base de germe de trigo, do que para os criados em folha de milho.

REVELO e RAUN (1964) criaram as lagartas de $S$. frugiperda sobre dieta artificial, proposta por Becton et al. (1962) durante 20 gerações sem perda do vigor, ou alterações no comportamento, em relação às criadas em folhas de milho.

BOWLING (1967) criou as lagartas sobre dieta artificial à base de feijão em ambiente com fotoperíodo de 14 horas, temperatura de 25 a $28^{\circ} \mathrm{C}$ e UR de 85-90\%, obtendo 31,2 dias de duração do período larval, pupas com peso médio de $432 \mathrm{mg}$ e 696 ovos/fêmea. RANDOLPH e WAGNER (1966) alimentaram as lagartas com dieta artificial à base de germe de trigo e obtiveram resultados semelhantes, porém com melhor fecundidade. 
à $27^{\circ} \mathrm{C}$ e $77 \%$ UR. verificaram que o período de incubação foi de 4 dias, a fase larval de 21 a 22 dias, com apenas 3 ec dises; a longevidade do adulto foi de 15 dias com um período de pré-oviposição de 5 dias com um total de 7 posturas.

BAILEY e CHADA (1968), comparando insetos cria dos sobre folhas de sorgo e sobre dieta artificial à base de caseína, verificaram que os ciclos de vida foram de 35,6 e 35,0 dias, respectivamente.

BURTON e PERKINS (1972), trabalhando com dieta artificial ã base de trigo e soja, constataram um período pupal de 13,45 dias e uma média de 1091 ovos/fêmea.

ESCALANTE (1974) obteve um ciclo de vida variá vel entre 88 e 120 dias à $10,8^{\circ} \mathrm{C}$ e $67 \%$ UR.

LUCCHINI (1977) verificou a ocorrência de dife rença na duração do ciclo de vida dos machos (31,27 diasl e das fêmeas $(30,1]$ dias). Em laboratório, obteve uma relação sexual de 1,25 macho para uma fêmea, e 1,05 macho para uma fêmea em condições de campo.

KASTEN et al. (1978) observaram que a dieta à base de feijão oferecia melhores possibilidade de substituir - alimento natural em criações de laboratório, embora a dieța natural tenha encurtado o ciclo do inseto.

BARFIELD et al. (1978) estabeleceram a tempera tura base para a fase de ovo em $18,3^{\circ} \mathrm{C}$. Obtiveram um ciclo to tal de 66 dias à $15^{\circ} \mathrm{C}$ e de 18 dìas à $35^{\circ} \mathrm{C}$.

SPARKS (1979l revisou a biologia de $S$. frugiperda, fornecendo dados sobre duração e comportamento de cada uma das fases.

COMBS e VALERIO (1980) verificaram que o melhor desenvolvimento dessa espécie ocorre à $25^{\circ} \mathrm{C}$.

FERRAZ (1982) constatou que a temperatura in- 
flui marcadamente em todas as fases do ciclo biológico desse inseto. Observou que a idade das plantas não afetou a duração de nenhuma fase imatura, porém as melhores viabilidades foram apresentadas por insetos que se alimentaram sobre folhas com 45 dias de idade.

2.5. Consumo e utilização de alimento por spodoptera spp.

SOO HOO e FRAENKEL (1966a) relataram que lagartas de Prodenia eridania (Craemer) [sinôrimo de Spodopteraeridania (Craemer)] aceitaram inicialmente muitas plantas de diferentes famílias, mas consumiram-nas com diferentes intensidades e não tiveram o mesmo desenvolvimento larval em todas elas. Esse fato indicou que as lagartas ou não ingeriram o suficiente ou não pude ram utilizar suficientemente o alimento ingerido. Assim, soo HOO e FRAENKEL (1966b) estudaram a taxa de ingestão, a porcen tagem de digestibilidade e a eficiência de conversão do alimento ingerido e do digerido durante 0 5 instar de $P$. eridania em 18 plantas diferentes, pertencentes a 13 famílias. Dez espécies vegetais foram eficientemente convertidas em bio massa. Algumas plantas não proporcionaram o crescimento larval por causa de um ou da combinação dos seguintes fatores : baixa digestibilidade, baixa eficiência de conversão e baixa taxa de consumo. Outros fatores que afetaram a eficiência foram o conteúdo de água, o conteūdo de proteína e possivelmente o teor de fibra. E concluíram que uma boa planta para o in seto se alimentar seria aquela que apresentasse uma correlação inversa entre o consumo de alimento e a eficiência de uti li zação.

BHAT e BHATTACHARYA (1978) estudaram o consumo e utilização de soja por spodoptera litura (Fabricius) a dife rentes temperaturas, com o objetivo de verificar as diferenças no desenvolvimento larval. As observações indicaram que as lagartas mantidas em temperaturas mais baixas tiveram um perío 
do de duração maior. O consumo de alimento cresceu com o aumento da temperatura. O CI foi maior no primeiro ínstar e decresceu com a idade. Em geral O CI cresceu gradualmente com o aumento da temperatura. A GR também cresceu com o aumento da temperatura, demonstrando a pequena utilização de alimento à baixas temperaturas. A AD variou consideravelmente com o ínstar, porém não sendo constatada uma correlação entre $A D$, ínstar e temperatura. Nos 30, 49,69 e 70 ínstares a AD caiu gradualmente com as temperaturas mais baixas. Constatou-se também que as lagartas fêmeas digerem melhor o alimento entre 15 e $25^{\circ} \mathrm{C}$, enquanto que os machos digerem melhor à $30^{\circ} \mathrm{C}$. A ECI foi mais alta à $20^{\circ} \mathrm{C}$ e caiu com o aumento da temperatura. A ECD não apresentou correlação com ínstar ou com a temperatura.

DUODU e BINEY (1981) estudaram a biologia e o consumo e utilização de alimentos por Spodoptera littoralis (Boisduval) em repoIho, 'Kenaf' (Hibiscus cannabinus), algodão e juta-do-congo (urena lobata). As lagartas alimentadas com repolho apresentaram o desenvolvimento larval mais rápido, enquanto que as alimentadas com folhas de algodão e juta tiveram o desenvolvimento mais lento e apresentaram um ínstar a mais. O ganho àe peso foi maior sobre repolho e menor em 'Kenaf'. As lagartas alimentadas com repolho apresenta ram alta digestibilidade e baixa ECD, as alimentadas com juta apresentaram baixo consumo, baixa digestibilidade e alta ECD, enquanto as alimentadas com 'Kenaf' apresentaram baixo consumo, baixo ECD e alta digestibilidade. Os autores concluíram que os dados sugeriram a ocorrência de um mecanismo de compen sação, que favorecia o insēto a utilizar os diferentes hospedeiros. Concluíram, também, que $S$. littoralis mostrou-se melhor adaptaàa ao repolho do que às outras plantas, o que, no entanto, pode ser devido ao fato do experimento ter sido iniciado com insetos criados sobre esta crucífera.

SCRIBER (1982), trabalhando com $S$, eridania, estudou o efeito da alimentação dos primeiros ínstares sobre o consumo, assimilação e conversão de biomassa vegetal nos 
ínstares subseqüentes. Foram testados três hospedeiros com di ferentes graus de preferência (Sorbus americana, Betula papyrifera e prunus serotina). Lagartas recém-eclodidas, descendentes de insetos criados sobre folhas de feijoeiro, foram alimentadas com os hospedeiros em teste até o 49 ou 50 ínstares larvais. As observações de consumo e utilização foram fei tas no 50 e/ou 69 ínstares, em insetos que foram mantidos sobre o mesmo alimento e em insetos que tiveram o alimento trocado, formando diferentes arranjos entre os hospedeiros testados. O pesquisador observou que não houve diferenças significativas na digestibilidade. Entretanto, os insetos alimenta dos nos primeiros ínstares com B. papyrifera e S. americana apresentaram sensível melhora na eficiência de utilização do nitrogênio. As lagartas que se alimentaram de $P$. serotina nos primeiros ínstares, apresentaram a melhor eficiência de assimilação de biomassa e utilização de nitrogênio. Porém, as pupas de alguns tratamentos apresentaram-se deformadas e morreram. Esse "stress" fisiológico manifestou-se no estágio pré-pupal como um alongamento e engrossamento dos insetos alimentados com $P$. serotina, embora os índices nutricionais não permitissem prever tais irregularidades. Possíveis mecanismos bioquímicos en volvidos (p. ex. indução de enzimas digestivas, e desintoxica ção de enzimas ou sua interação com sistemas hormonais) não foram analisados.

MANUWOTO E SCRIBER (19.82) estudaram o consumo e utilização de três genótipos de milho por $S$, eridania. Foram avaliadas três variedades de milho com diferentes mecanis mos de resistēncia à alimentação foliar pela broca-do-milho ostrinia nubilalis (Hüebner). As variedades de milho foram: B49 que tem alta concentração de DIMBOA (2,4 dihidroxi-7-metoxi (2H)- 1,4 benzoxazina $(4 \mathrm{HL})$, San Juan com mecanismo de resistência à broca diferente do DIMBOA, e uma variedade susceptível sem-DIM BOA. As lagartas alimentadas com folhas de milho das variedades B49 e S.J. apresentaram, no penûltimo ínstar, um custo me 
tabólico superior a $80 \%$ da biomassa assimilada, entretanto, apresentaram uma elevada taxa de consumo o que permitiu as la gartas atingirem uma taxa de crescimento maior do que a esperada. A alta taxa de consumo e a recuperação da eficiência de conversão no ültimo ínstar resultou num crescimento mais rápido sobre as variedades $B 49$ e SJ. A versatilidade da alimentação e a capacidade de desintoxicação dessa espécie polífaga são provavelmente, as principais explicacões para o desenvolvimento de $S$, eridania sobre plantas resistentes à 0 . nubilalis. 


\section{MATERIAL E METODOS}

Esse trabalho foi desenvolvido no laboratório de Entomologia do Departamento de Defesa Fitossanitária da Fa culdade de Ciências Agronômicas da Universidade Estadual Paulista "Júlio de Mesquita Filho" (UNESP), "Campus" de Botucatu, mantido à temperatura de $25 \pm 2^{\circ} \mathrm{C}$, umidade relativa de $60 \pm 10 \% \mathrm{e}$ fotoperíodo de 14 horas.

3.1. Criação de manutenção

Inicialmente, foram obtidos ovos de Spodoptera frugiperda (J.E. Smith, 1797L, provenientes de uma criação em dieta artificial conduzida no laboratório de Entomologia da ESALQ-USP, sendo estabelecida uma criação de manutenção para fornecer insetos para essa pesquisa. Nessa criação, os ovos eram colocados sobre papel de filtro umedecido, no in terior de placas de "Petri" de 9,5 cm e mantidos nas condições de laboratório até a eclosão das lagartas. As lagartas recém-eclodidas eram removidas com o auxílio de um pequeno pincel e introduzidas em tubos de vidro, com o fundo chato, de $2 \mathrm{~cm}$ de diâmetro e $8 \mathrm{~cm}$ de altura, contendo dieta artifici al proposta por BOWLING (1967) e modificada por KASTEN et al. (1978) que apresenta a seguinte composição:

$$
\text { Feijão (var. rosinha) .... 100,0 g }
$$


Levedura $\ldots \ldots \ldots \ldots \ldots \ldots \ldots \ldots$ 15, 0 g

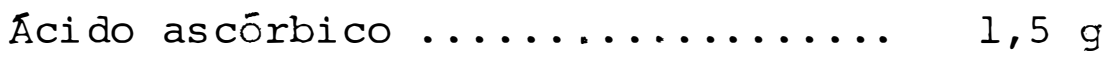

Nipagin (metil p-hidroxibenzoato)... $1,0 \mathrm{~g}$

Ácido sórbico ................. 0,5 g

Formaldeído ................. $1,0 \mathrm{~g}$

Agar ........................... 6,0

Água .............................. $375,0 \mathrm{ml}$

Essa dieta foi preparada de acordo com as técnicas descritas por PARRA (1979).

Para evitar o canibalismo, característico dessa espécie, as lagartas foram mantidas individualizadas nos tubos, contendo dieta, até atingir a fase de pupa. As pupas eram retiradas, "sexadas" (BUTT e CANTU, 1962) e colocadas em grupos de 5 casais no interior de gaiolas cilíndricas de $15 \mathrm{~cm}$ de diâmetro por $20 \mathrm{~cm}$ de altura, construídas de tela, tendo as extremidades superior e inferior fechadas por placas de "Petri". Após a emergência dos adultos lhes era fornecido algodão embebido em solução aquosa de sacarose ã 10\%, e introdu zida uma folha de papel jornal revestindo internamente a gaio la, como substrato de postura. Diariamente, as massas de ovos eram recortadas e colocadas sobre papel de filtro umedecido, no interior de placas de "Petri", para incubação, conforme descrito anteriormente.

3.2. Manutenção das plantas

Lagartas recém-eclodidas, provenientes de ovos da criação de manutenção, foram alimentadas, durante toda a fase larval, com folhas das seguintes gramineas: milho (Zea mays), variedade HMD-7974; trigo (Triticum aestivum), variedade Alonda; e sorgo sacarino (Sorghum vulgare), variedade BR-501.

Essas plantas foram cultivadas em vasos de alu mínio de formato tronco-cônico com $15 \mathrm{~cm}$ de altura por $15 \mathrm{~cm}$ de 
diāmetro na extremidade superior e $9 \mathrm{~cm}$ de diâmetro na base. No interior desses vasos foi colocada uma mistura de 2 partes de terra, I parte de areia lavada e 1 parte de esterco de cur ral. Essa mistura foi previamente autoclavada durante 1 hora à 1 atm.

Em cada vaso foram cultivadas 4 plantas que re ceberam, a intervalos regulares de 10 dias, aproximadamente 3 g da seguinte mistura de adubos:

$\begin{array}{lrl}\text { Sulfato de amônio } & 50 \mathrm{~g} \\ \text { Superfosfato simples } & 100 \mathrm{~g} \\ \text { Cloreto de potássio } & 30 \mathrm{~g}\end{array}$

Essas plantas foram mantidas em casa-de-vegeta ção, onde recebiam três irrigações diārias. A partir do 30 o dia após a germinação, foram feitas coletas diárias de folhas para alimentar os insetos em estudo no laboratório.

3.3. Estudo do consumo e utilização de alimentos.

O estudo do consumo e utilização de alimentos foi feito para toda a fase larval, instalando-se um experimen to com 3 tratamentos e 10 repetições. Os tratamentos foram mi lho, trigo e sorgo, variedades anteriormente citadas. Cada parcela foi formada por grupos de 10 lagartas, mantidas individualizadas em placas de "Petri" de 9,5 cm, para evitar o ca nibalismo, totalizando 100 placas por tratamento. Dessa forma os dados referentes a cada parcela foram tomados de 10 placas e calculada a média. Esse artifício foi necessário para melhor sensibilização do equipamento de medição, uma balança analítica "Sartorius" com aproximação de 0,0001 g, minimizando assim o erro experimental.

Em cada uma das placas foi introduzida uma esfera de algodão de aproximadamente $1 \mathrm{~cm}$ de diâmetro, embebi do em āgua, para manter a umidade. Em seguida, foram introduzidos 
o alimento e a lagarta.

Diariamente foi trocado o alimento, retiradas as fezes e avaliado o peso de alimento ingerido, o peso das fezes produzidas e o peso das lagartas. Para reduzir os erros, os dados foram obtidos em peso seco. Para isso, o procedimento foi o seguinte:

\subsubsection{Peso de alimento ingerido}

O "Peso de Alimento Ingerido" (I) foi calculado indiretamente, subtraindo-se o "Peso da Sobra de Alimento" do "Peso de Alimento Fornecido" no dia anterior.

Para a obtenção do"Peso Seco do Alimento Ingerido"foi utilizado o seguinte artifício: as folhas eram coletadas dos vasos, trazidas ao laboratório e cortadas em pedaços de aproximadamente $10 \mathrm{~cm}$ de comprimento. Depois eram separadas em 10 lotes correspondentes à cada uma das parcelas do tratamento. A quantidade de folhas que compunha caảa um desses lotes era estimada em função do tamanho das lagartas. De cada um dos pedaços de folha componentes de um lote era retirado cerca de $1 / 3$ do comprimento e colocado num recipiente, previamente tarado, para determinação do peso seco. As partes de folha restantes eram pesadas para obtenção do "Peso Verde do Alimento Fornecido" e distribuídas entre as 10 placas de "Petri" que representavam a parcela, para alimentar os insetos.

Os recipientes para determinação do peso seco, caixas cilíndricas medindo $5 \mathrm{~cm}$ de diâmetro por $5 \mathrm{~cm}$ de altura, construídas em alumínio, dotadas de tampa, devidamente identi ficadas por um número, eram pesados imediatamente após receber o material correspondente a $1 / 3$ da parcela, obtendo-se 0 "Peso Verde da Alíquota"; em seguida este material era levado à estuda à $65^{\circ} \mathrm{C}$ onde permanecia durante 24 horas. Após seca- 
gem, os recipientes eram retirados e resfriados em dessecador durante 2 horas, sendo a seguir pesados, obtendo-se o "Peso Seco da Alíquota". Assim, o "Peso Seco do Alimento Fornecido"era obtido através da fórmula:

$$
P S F=\frac{P V F \times P S A}{P V A}
$$

onde:

$$
\begin{aligned}
& \mathrm{PSF}=\text { peso seco do alimento fornecido } \\
& \mathrm{PVF}=\text { peso verde do alimento formecido } \\
& \mathrm{PSA}=\text { peso seco da alíquota } \\
& \mathrm{PVA}=\text { peso verde da alíquota }
\end{aligned}
$$

Após 24 horas, a parte do alimento fornecido (PVF) não ingerida pelo inseto, era retirada das 10 placas de "Petri" componentes da parcela, introduzida no recipiente para determinação do peso seco, já descrito, e, pesada para se conhecer o "Peso Verde da Sobra de Alimento" e levada à estufa como para a determinação do PSA. Após a secagem era determinado o "Peso Seco da Sobra de Alimento".

através da fórmula:

o "Peso Seco do Alimento Ingerido" foi obtido

$$
P S T=P S F-P S S
$$

onde:

$$
\begin{aligned}
& \text { PSI }=\text { peso seco do alimento ingerido } \\
& \text { PSF }=\text { peso seco do alimento fornecido } \\
& \text { PSS }=\text { peso seco da sobra de alimento }
\end{aligned}
$$

Em seguida dividia-se por 10 para se conhecer - valor correspondente a uma lagarta, obtendo-se assim o pará metro (I) (Peso de Alimento Ingerido ou Consumido) empregado nos cálculos dos índices de consumo e utilização. Essa operação foi realizada diariamente durante toda a fase larval. 
As fezes coletadas das 10 placas componentes de cada parcela eram recolhidas em um recipiente para peso se co e pesadas, obtendo-se o "Peso Fresco de Excremento"; em seguida eram levadas à estufa para secar, conforme descrito para o alimento. Após secagem, obtinha-se o"Peso Seco do Excremento"; dividindo-o por 10 obtinha-se o"Peso do Excremento"(F) de uma lagarta.

A avaliação diária do peso de fezes produzidas foi iniciado no 39 dia de vida das lagartas, porque a quantidade produzida nos 2 primeiros dias não sensibilizava a balan ça. Dessa forma, o primeiro dado obtido representou a produção de fezes acumulada no período.

\subsubsection{Peso das lagartas}

Para se obter o"Peso Seco Diário" de lagartas foi necessário a obtenção do "Peso Vivo Diário" das lagartas. Assim, diariamente, as 10 lagartas correspondentes a cada par cela eram colocadas em um único recipiente e pesadas de uma só vez. No final da fase, quando os insetos pararam de se ali mentar, foram retiradas 5 lagartas de cada parcela, colocadas em um recipiente para determinação do peso seco, devidamente iâentificado e tarado, e pesadas para se obter o peso vivo fi nal das lagartas. Em seguida foram mortas com clorofórmio e levadas à estuda a $65^{\circ} \mathrm{C}$ durante 36 hōras. Quando retiradas fo ram resfriadas em dessecador durante 2 horas e pesadas para se obter o"Peso Seco Final"das lagartas. Calculou-se então o peso seco diário de cada lagarta atravēs da fórmula:

$$
\text { PSL }=\frac{\text { PSLf } \times \text { PVL }}{10 \times \text { PVLf }}
$$

onde: 


$$
\begin{aligned}
\text { PSL }= & \text { peso seco diário de cada lagarta } \\
\text { PSLf = } & \text { peso seco final das } 5 \text { lagartas de cada parcela } \\
\text { PVL = } & \text { peso vivo diário das } 10 \text { lagartas de cada parce } \\
& \text { la } \\
\text { PVLf = } & \text { peso vivo final das } 5 \text { lagartas de cada parcela }
\end{aligned}
$$

A avaliação do peso das lagartas também só pôde ser iniciada no 30 dia de vida pois, como no caso das fezes, nos dois primeiros dias o peso foi insuficiente para sen sibilizar a balança. O"Peso Seco Díario" de cada lagarta, da maneira como foi obtido, foi cumulativo. Assim, o"Peso Seco de cada Lagarta"no último dia da fase larval é igual ao ganho total de peso (B). O"Peso Médio das Lagartas"( $\bar{B})$ foi obtido através da fórmula: $\frac{\sum P S L}{N}$ onde $N$ é o número de dados de PSL.

As 5 lagartas restantes em cada parcela foram conduzidas à fase seguinte, obtendo-se o"Peso das Pupas", 24 horas após a pupação.

\subsubsection{Inaices de consumo e utilização}

Com os dados assim obtidos foram calculados os índices de consumo e utilização de alimentos conforme proposto por WALDBAUER (1968) com as alterações feitas por SCRIBER e SLANSKY JR. (1981L, quais sejam:

$$
\begin{aligned}
& \mathrm{RCR}=\frac{I}{\overline{\mathrm{B}} \times \mathrm{T}} \\
& \mathrm{RMR}=\frac{\mathrm{M}}{\overline{\mathrm{B}} \times \mathrm{T}} \\
& \mathrm{RGR}=\frac{\mathrm{B}}{\overline{\mathrm{B}} \times \mathrm{T}} \\
& \mathrm{ECI}=\frac{\mathrm{B} \times 100}{\mathrm{I}} \times
\end{aligned}
$$




$$
\begin{aligned}
& \mathrm{AD}=\frac{I-F}{I} \times 100 \\
& \mathrm{ECD}=\frac{B}{I-F} \times 100
\end{aligned}
$$

onde:

$$
\begin{aligned}
& \mathrm{RCR}=\text { taxa de consumo relativo } \\
& \mathrm{RMR}=\text { taxa metabólica relativa } \\
& \mathrm{RGR}=\text { taxa de crescimento relativo } \\
& \text { ECI = eficiência de conversão do alimento ingerido } \\
& A D=\text { digestibilidade aproximada } \\
& E C D=\text { eficiência de conversão do alimento ingerido } \\
& m \text { = tempo de duração do período de alimentação } \\
& \mathrm{I}=\text { alimento ingerido (consumido) durante } \mathrm{T} \\
& \mathrm{B} \text { = alimento utilizado para o crescimento durante } \mathrm{T} \\
& \overline{\mathrm{B}} \quad \text { = peso médio das lagartas durante } \mathrm{T} \\
& \mathrm{F}=\text { alimento não digerido + produtos de excreção du } \\
& \text { rante } \mathrm{T} \\
& M=(I-F)-B=\text { alimento metabolizado durante } T \\
& (I-F)=\text { alimento assimilado durante } \mathrm{T} \\
& \text { 3.3.5. Determinação da área foliar consumida }
\end{aligned}
$$

Diariamente eram retiradas alíquotas de $1 \mathrm{~cm}^{2}$, com auxilio de um vasador, das folhas que eram fornecidas como alimento para os insetos. Essas áreas eram agrupadas em 4 lotes de 10 e cada lote colocado em um recipiente para determinação do peso seco. O material era pesado obtendo-se o peso fresco e, em seguida, levado à estufa para secar (peso seco). Ao final do experimento os dados foram somados e calculados o peso fresco médio em $\mathrm{mg} / \mathrm{cm}^{2}$ e o peso seco médio em $\mathrm{mg} / \mathrm{cm}^{2} \mathrm{pa}-$ ra cada tratamento. Com o auxílio desse dado o "Peșo de Alimento Ingerido" (IL foi transformado em "Ârea Foliar Consumida" (AC). 


\subsubsection{Análise estatística}

Os dados obtidos foram submetidos à análise de variāncia, sendo as médias comparadas pelo teste de Tukey, ao nível de 5\% de probabilidade. Os dados dos índices AD, ECI, e $E C D$, por serem expressos em porcentagem, foram transformados em arc. sen $\sqrt{\mathrm{x}}$ e, RMR, RCR e RGR transformados em $\sqrt{\mathrm{x}+\mathrm{I}}$.

\section{4. Desenvolvimento larval}

Para o acompanhamento do desenvolvimento larval foram instalados 3 grupos de 10 placas de "Petri", corres pondendo aos tratamentos milho, trigo e sorgo, sendo observa dos: duração da fase larval, a largura da cápsula cefálica e o nụ mero de ínstares. Cada placa recebeu uma lagarta recém-eclodi da e o alimento correspondente, que foi trocado diariamente. As lagartas foram observadas ảiariamente e tiveram a largura da cāpsula cefálica medida, através de uma ocular graduada adaptada a microscópio estereoscópico, para determinação do número e duração de cada ínstar

3.5. Influência da alimentação da fase larval sobre a sele ção hospedeira pelas lagartas descendentes.

o objetivo desse... experimento foi verificar pos síveis interferências do alimento utilizado, por uma geração, sobre a capacidade da prole selecionar seu alimento.

Para esse teste foram criadas lagartas, durante 2 gerações consecutivas, sobre cada uma das três gramíneas estudadas: milho, trigo e sorgo. As lagartas recém-eclodidas provenientes de insetos alimentados com cada uma das gramíneas foram consideradas como um tratamento. Cada tratamento foi se parado em 10 lotes de 20 lagartas, de tal maneira que cada um foi considerado como uma repetição, a qual correspondeu uma 
"arena" de teste.

As "arenas" para o teste de seleção do alimento constituíram-se ảe uma placa de "Petri" de $15 \mathrm{~cm}$ de diàmetro fechaca contendo um pedaço de folha de $5 \mathrm{~cm}$ de comprimento de cada uma das gramíneas testadas. Esses pedaços de folha foram colocados de tal maneira a ter uma extremidade voltaōa para - centro da placa e a outra para a periferia, na qual foi colocado um algodão úmido, para manter a turgidez dos vegetais. No centro da "arena" foram liberadas as 20 lagartas recém-eclodidas, que puderam escolher livremente o alimento pre ferido, em função do condicionamento da geração anterior. Após 24 horas as placas foram abertas e avaliado o número de laga $\underline{\underline{r}}$ tas presentes sobre cada uma das folhas fornecidas.

3.6. Influéncia da alimentação da fase larval sobre a sele ção hospedeira pelos adultos

o objetivo desse experimento foi verificar se - alimento utilizado durante a fase larval influenciava a escolha do local ou do hospedeiro, no qual as fêmeas fariam a oviposição.

Foram criadas lagartas sobre cada uma das três gramíneas estudadas: milho, trigo e sorgo, até serem obtidas as pupas, as quais foram colocakas em gaiolas separadas de acor do com a origem, até a emergência dos adultos.

Para contornar possíveis distorções no comportamento de oviposição, causadas pelo tamanho das gaiolas, os testes foram realizados utilizando-se gaiolas grandes, com. formato de um paralelepípedo, medindo 30 x $30 \mathrm{~cm}$ de base por $60 \mathrm{~cm}$ de altura, construídas em plástico, e gaiolas pequenas, cilíndricas, medindo $15 \mathrm{~cm}$ de diâmetro por $30 \mathrm{~cm}$ de altura, construídas em tela. No interior de cada uma das gaiolas foi introduzida uma planta de milho, uma de trigo e uma de sorgo com aproximadamente $11 \pm 3 \mathrm{~cm}$ de altura, cultivadas em copos - 
plásticos de $4 \mathrm{~cm}$ de diâmetro por $5 \mathrm{~cm}$ de altura.

os adultos provenientes de cada gramínea repre sentaram um tratamento e foram introduzidos, em grupos de três casais, em 10 gaiolas de teste sendo 5 pequenas e 5 gran des. Esses adultos foram alimentados com uma solução aquosa de sacarose à 10\%. Realizaram-se contagens diárias do número de ovos até a morte das mariposas. 


\section{RESULtados E DISCUSSÃO}

4.1. 0 método

O exame dos coeficientes de variação (CV) apre sentados nas Tabelas 1,2 e 3 mostra que houve uma certa tendência de uniformização dos dados conforme os insetos se desenvolviam. Isso ocorreu porque, com o desenvolvimento das lagartas, as quantidades de material a serem medidas se tornaram maiores, diminuindo os erros de operação e medição. Como foi utilizada uma balança analitica com precisão de 0,0001 g, a avaliação de quantidades ínfimas (registradas no início de desenvolvimento do insetol, que sensibilizam apenas a última casa decimal, quase sempre é imprecisa.

Nesse tipo de trabalho, o "Peso seco do Alimen to Fornecido" é estimado através de uma alíquota e o "Peso de Alimento Ingerido" (I) é obtido subtraindo-se o "Peso seco da Sobra de Alimento" do "Peso Seco do Alimento Fornecido". Quan do essa diferença é pequena (da ordem de 0,l mg) é comum serem encontrados valores negativos para o (I) porque a balança não consegue registrá-la com precisão, e também porque esse erro é ampliado pelos cálculos matemáticos utilizados na determinação do "Peso seco do Alimento Fornecido".

Outra fonte de erro está no momento da coleta 
de material para as pesagens. Podem ocorrer pequenas perdas por ocasião da coleta da sobra de alimento e da separação das fezes. Assim, quase sempre é recolhida pequena porção de fezes junto com a sobra de alimento, o que interfere na avaliação do "Peso do Alimento Ingerido (I)". O mesmo fato pode ocorrer com a coleta das fezes produzidas, que poâerá ter sua ava liação prejudicada pela presença de partículas da sobra de alimento.

Esses erros todos podem ser minimizados com 0 aumento da quantidade de material a ser manipulaāa de uma só vez. Por esse motivo, foram utilizadas parcelas de 10 insetos. Assim, a quantidade de material a ser avaliada foi maior, conseqüentemente os erros, principalmente os atribuidos ao opera dor, e às perdas proporcionadas pelo próprio método, foram re lativamente menores. Se as medições tivessem sido feitas em parcelas compostas de insetos individualizados, a quantidade de material a ser pesado teria sido muito pequena e os erros relativamente maiores.

Esse fato pode ser confirmado observando-se os dados de consumo de alimento (Tabela 1 e Figura l) que foram avaliados desde o primeiro dia. No início, quando o consumo era mínimo, o coeficiente de variação foi bem alto demonstran do uma maior variação dos dados. Porém, com o desenvolvimento do inseto e com o aumento da ingestão de alimentos o CV apresentou uma queda acentuada, conforme pode ser observado na Fi gura L demonstrando a maior exatidão dos dados. A Fig̣ura 1 mostra que o CV atingiu valores diferentes conforme o alimento consumido, o que pode ser explicado em função da qualidade (viabilidade segundo KOGAN, 1975) do hospedeiro, porém, de uma maneira geral, apresentou uma queda semelhante nos três tratamentos em função do tempo, ou seja, com o aumento das quantidades a serem avaliadas. 


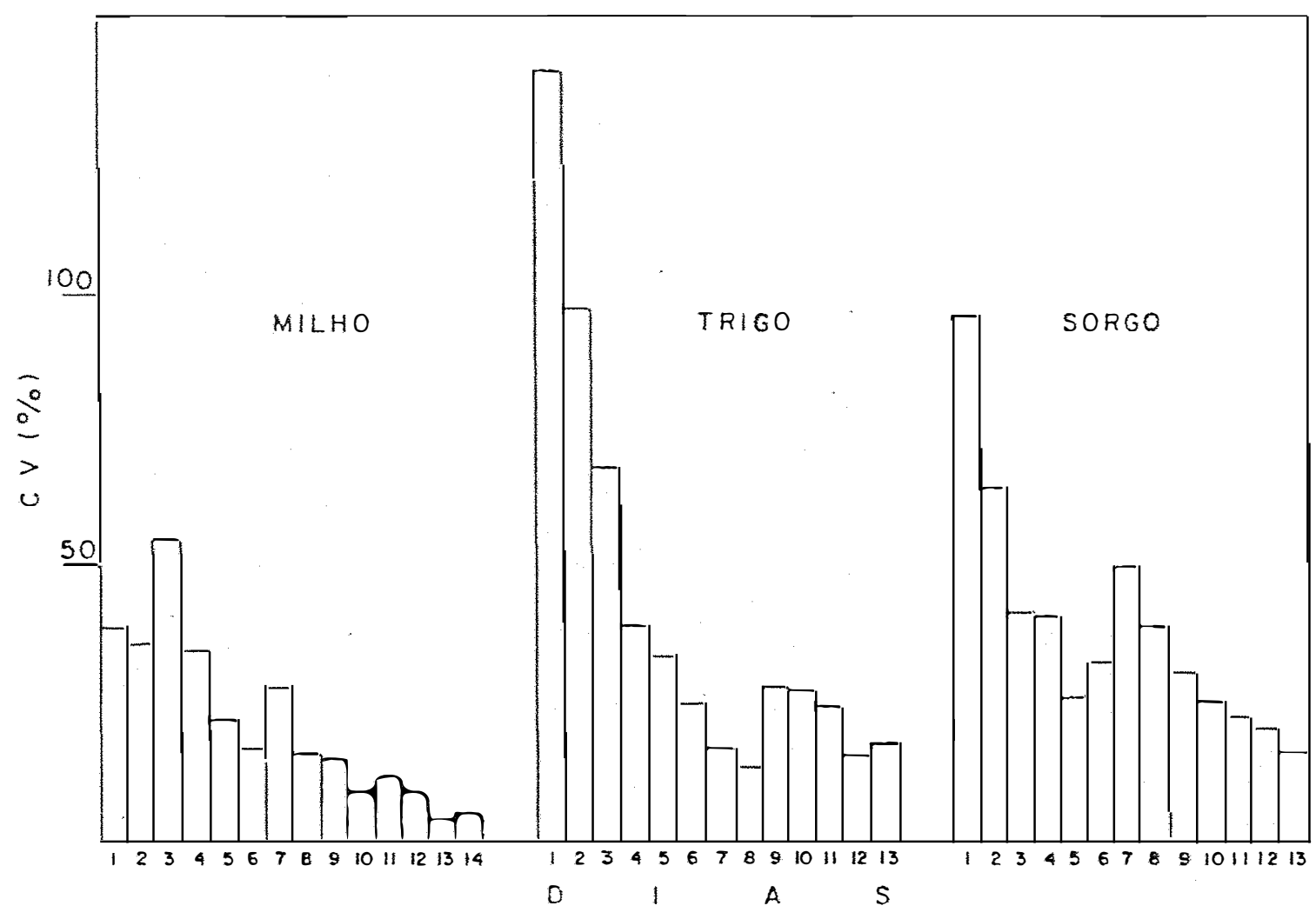

Figura 1 - Coeficiente de variação (CV) das médias de consumo diário acumulado das lagartas de $S$. frugiperda cria

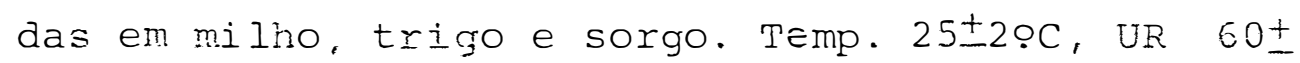
$10 \%$ e fot. $14 \mathrm{~h}$.

Isso também é válido para a avaliação do peso de fezes produzidas (Tabela 2) e para o ganho de peso corpóreo (Tabela 3). Porém, como as avaliações desses parāmetros se iniciaram no 39 dia, a quantidade de fezes acumuladas nas placas de "Petri" e o peso ganho pelas lagartas já haviam sido suficientes para se obterem dados mais uniformes. Mesmo as sim, pode-se observar que os insetos alimentados sobre trigo ainda apresentaram no 39 e 49 dias um $C V$ mais alto que nos de mais. No caso da produção de fezes, esse CV mais alto no $30 \bar{e}$ 40 dias pode ser decorrência da pequena quantidade produzida pelos insetos nesse perío. Esses dados podem ser verificados na Tabela 2, once no 30 dia os insetos alimentados em tri go produziram 2 e 6 vezes menos fezes que os alimentados com milho e sorgo, respectivamente. 
Outros fatores podem ter interferido sobre o CV mais alto no início do experimento, como por exemplo a aceitação do hospedeiro. Entretanto, a observação da tendência geral dos coeficientes de variação não deixa dúvida de que houve interferência das quantidades a serem avaliadas na precisão dos dados, principalmente nos primeiros instares, mesmo tomando-se a precaução de se trabalhar com parcelas de 10 insetos.

4. 2. Parámetros avaliados

Os dados de alimento consumido (I), fezes produzidas (F) e peso ganho (B) pelas lagartas de S. frugiperda, obtidos durante o experimento, são apresentados nas Tabelas 1 , 2 e 3 e nas Figuras 2,3 e 4, respectivamente.

\subsubsection{Consumo de alimento (I)}

As folhas de milho, trigo e sorgo foram igualmente ingeridas no 19, 29 e 3? dias (mabela 1). A partir do 30 dia houve maior consumo de sorgo e menor de trigo. por outro lado, os valores do milho foram intermediários, praticamente não diferindo do trigo, até o l2o dia. Entretanto, na passagem do 120 para 0139 dia as lagartas mantidas em trigo ingeriram $45 \mathrm{mg}$, as co sorgo $48 \mathrm{mg}$, enquanto as do milho consumiram $99 \mathrm{mg} e$ ainda permaneceram se alimentando por mais um dia, com um consumo de $130 \mathrm{mg}$. Observando-se a Figura 2, percebe-se claramente que enquanto as lagartas que se alimentavam de trigo e sorgo apresentaram, no último dia de ativida de alimentar, uma redução na quantidade ingerida, as criadas sobre milho mantiveram o ritmo de alimentação. Dessa forma, no cômputo geral o milho foi a gramínea mais consumida, o sor go a intermediária e o trigo a menos ingerida. 


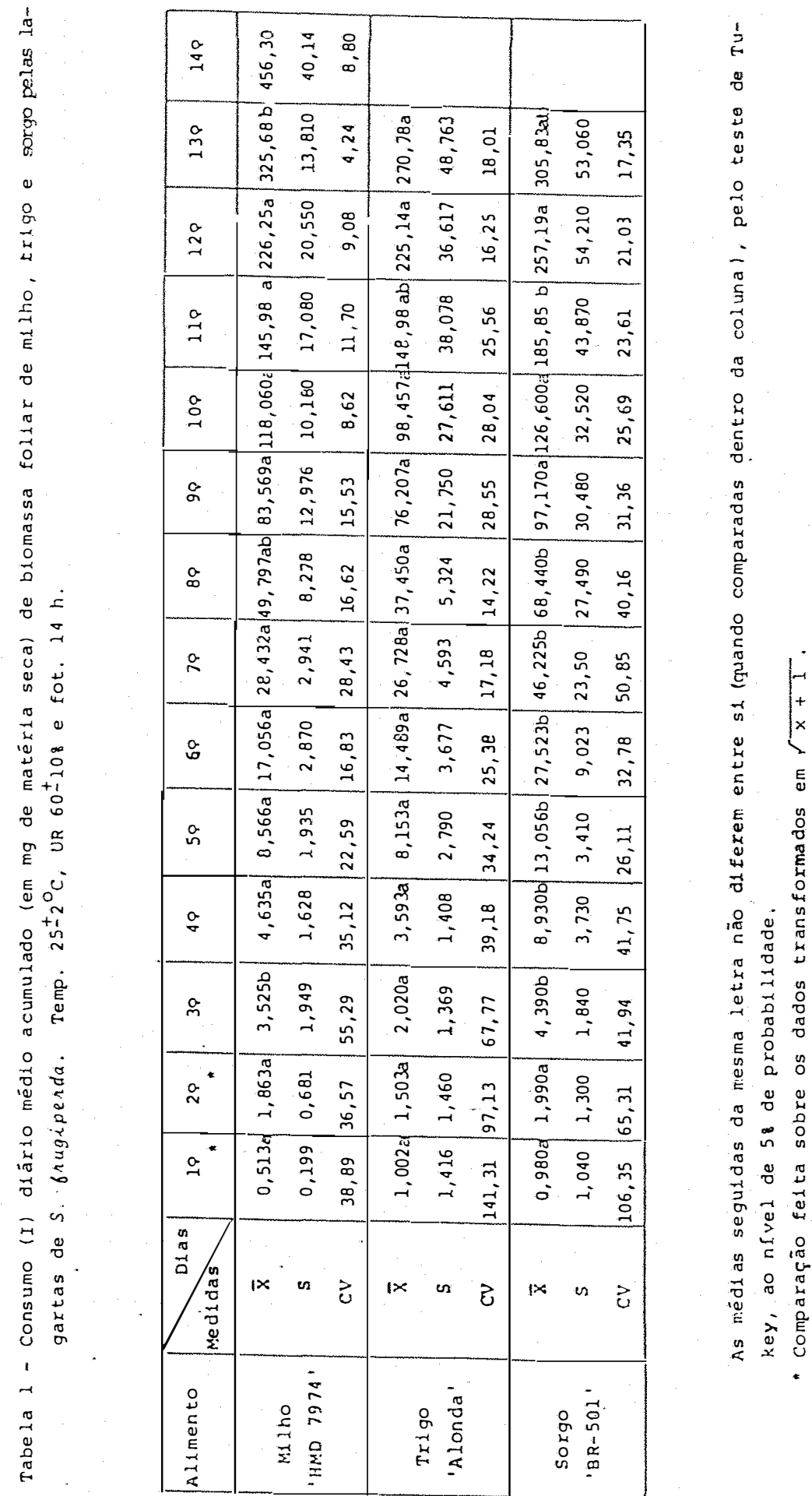




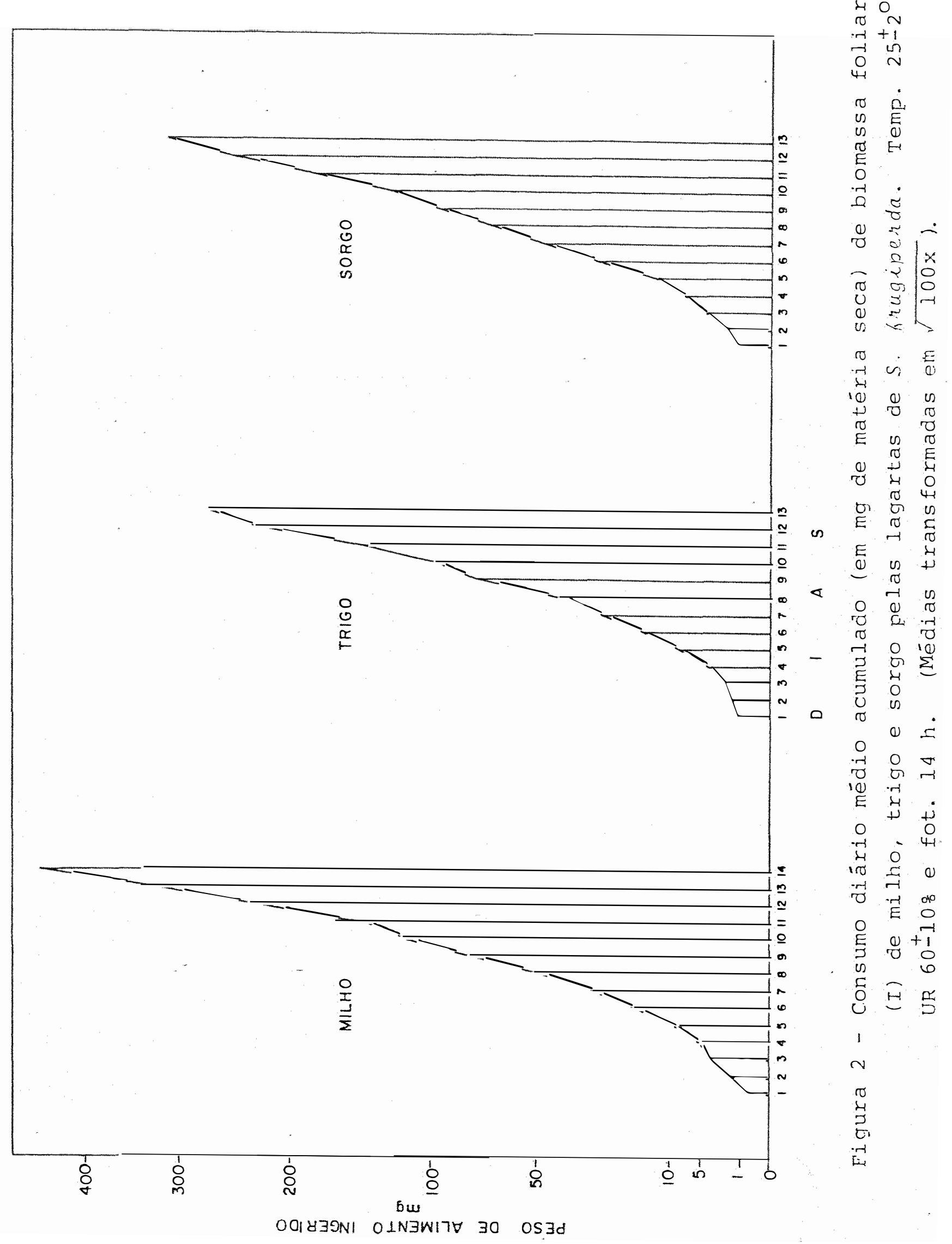




\subsubsection{Produçào de fezes (F)}

As lagartas que ingeriram folhas de trigo apre sentaram uma produção de fezes menor do que aquelas alimentadas com folhas de sorgo, durante toda a fase larval (Tabela 2 e Figura 3). Entretanto, as lagartas alimentadas com milho ti veram uma produção de fezes variável, assemelhando-se no início às lagartas criadas em trigo, e no final às mantidas em sorgo. Porém, observando-se a Figura 3, nota-se que as curvas de excreção diária das lagartas criadas em milho e em trigo foram. semelhantesaté o 129 dia. A curva de produção de fezes dos in setos do sorgo apresentou oscilações mais acentuadas até o 70 dia, quando então se tornou semelhante à do milho.

No último dia de atividade alimentar as lagartas criadas em sorgo e em trigo apresentaram uma redução na quantidade excretada, especialmente no ültimo substrato. Entretanto, as lagartas alimentadas com milho mantiveram o ritmo de excreção no último dia de atividade alimentar pois, nes se àia apresentaram um aumento na ingestão de alimentos (Figu ra 2).

Em termos gerais, as lagartas que consumiram milho, apresentaram uma produção ce fezes sicnificativamente maior que as do sorgo, devido ao dia a mais de atividade alimentar.

4.2.3. Ganho de Eiomassa (B)

As lagartas alimentadas com folhas de milho apresentaram um ganho de peso corpóreo inferior às outras atéo 130 dia đa fase larval, mesmo tendo ingerido mais alimento, enquanto que as lagartas alimentadas com folhas de trigo e de sorgo praticamente não diferiram entre si (Tabela 3). De um modo geral, o crescimento dos insetos foi bastante semelhante 


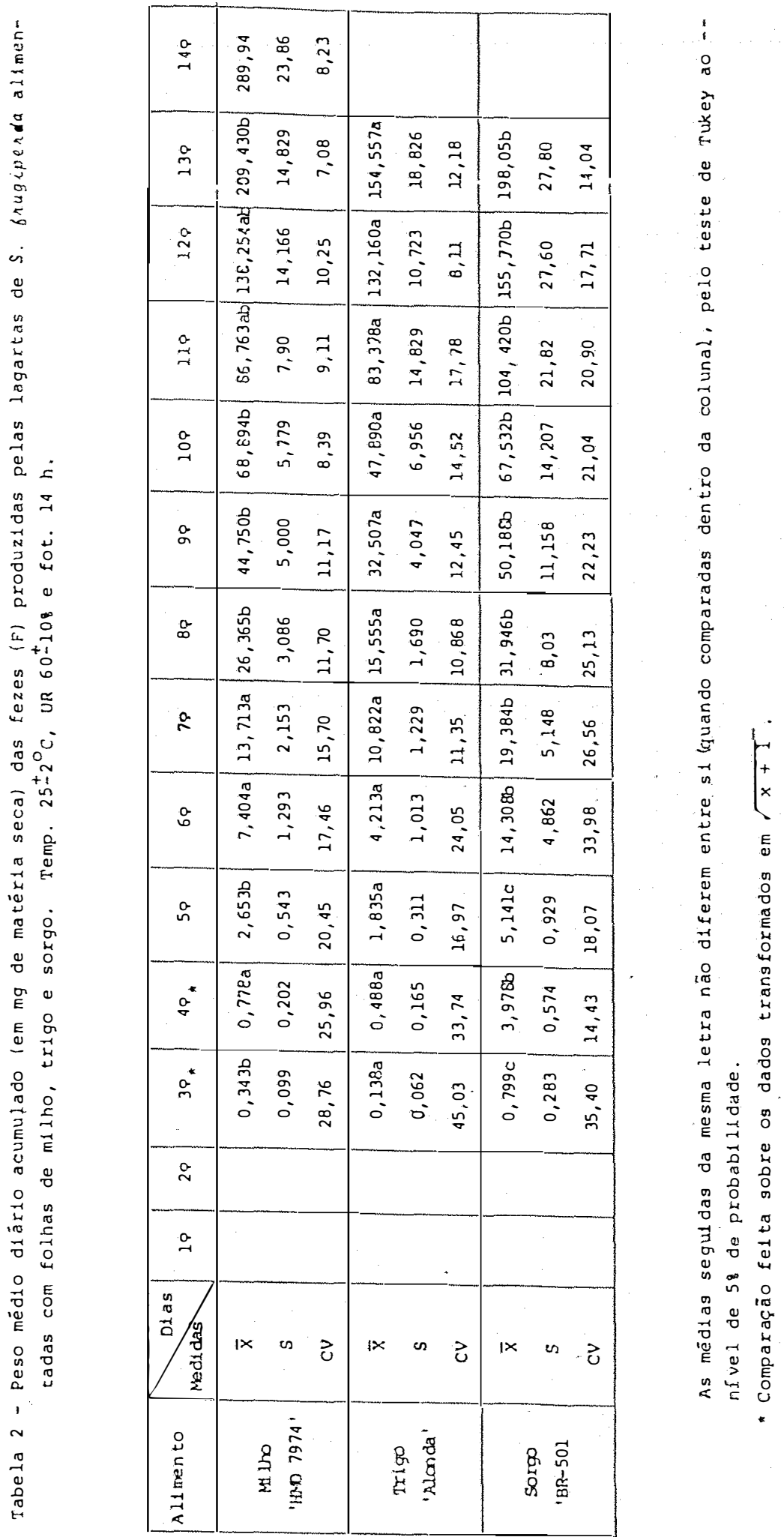




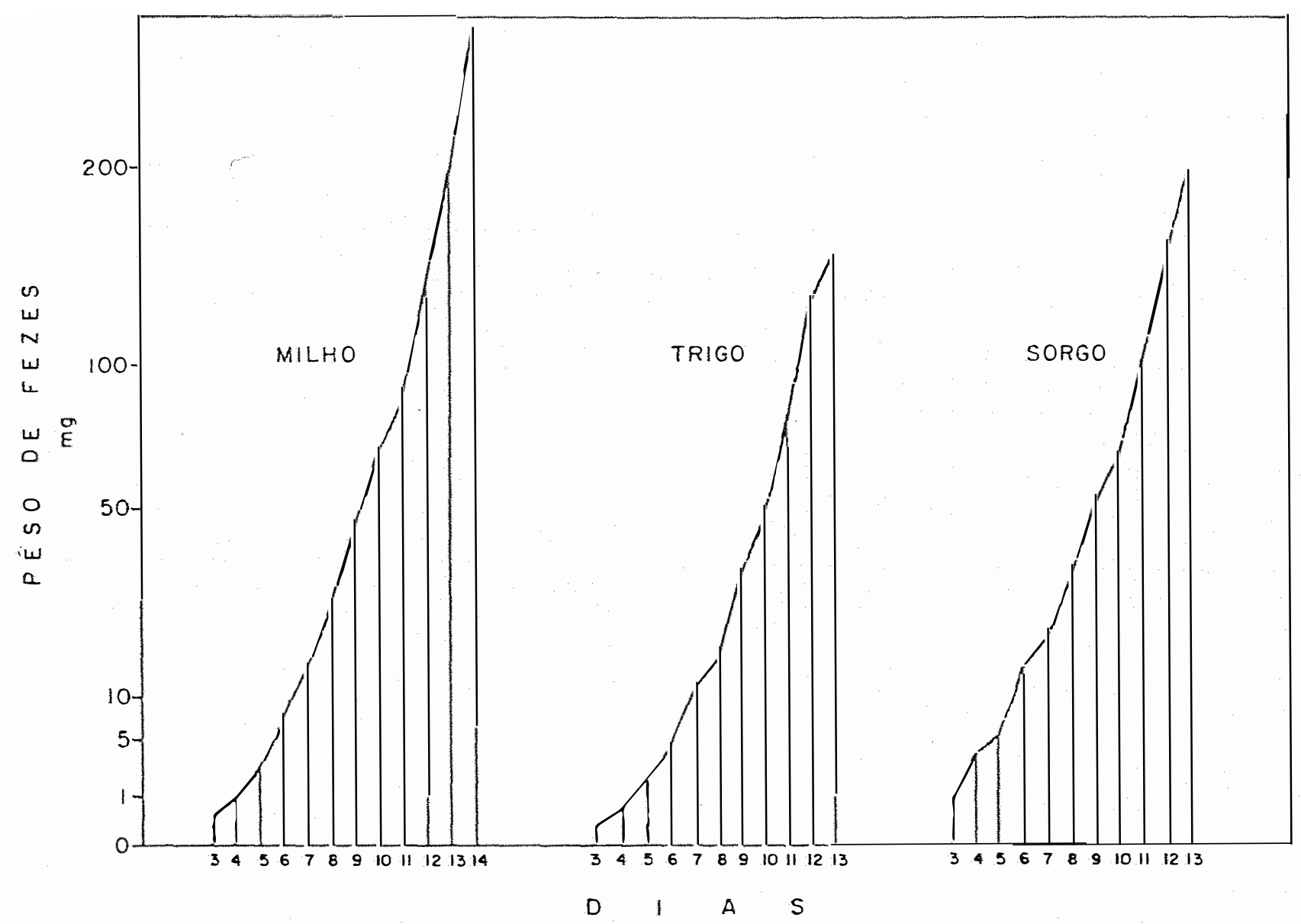

Figura 3 - Peso áiário médio acumulado (em mg de matéria se ca) das fezes (F) produzidas pelas lagartas de S. frugiperda alimentadas com folhas de milho, trigo e sorgo. Temp. $25 \pm 2^{\circ} \mathrm{C}$, UR $60 \pm 10 \% \mathrm{e}$ fot. $14 \mathrm{~h}$. (Méáias transformadas em $\sqrt{100 \mathrm{x}}$ ). 


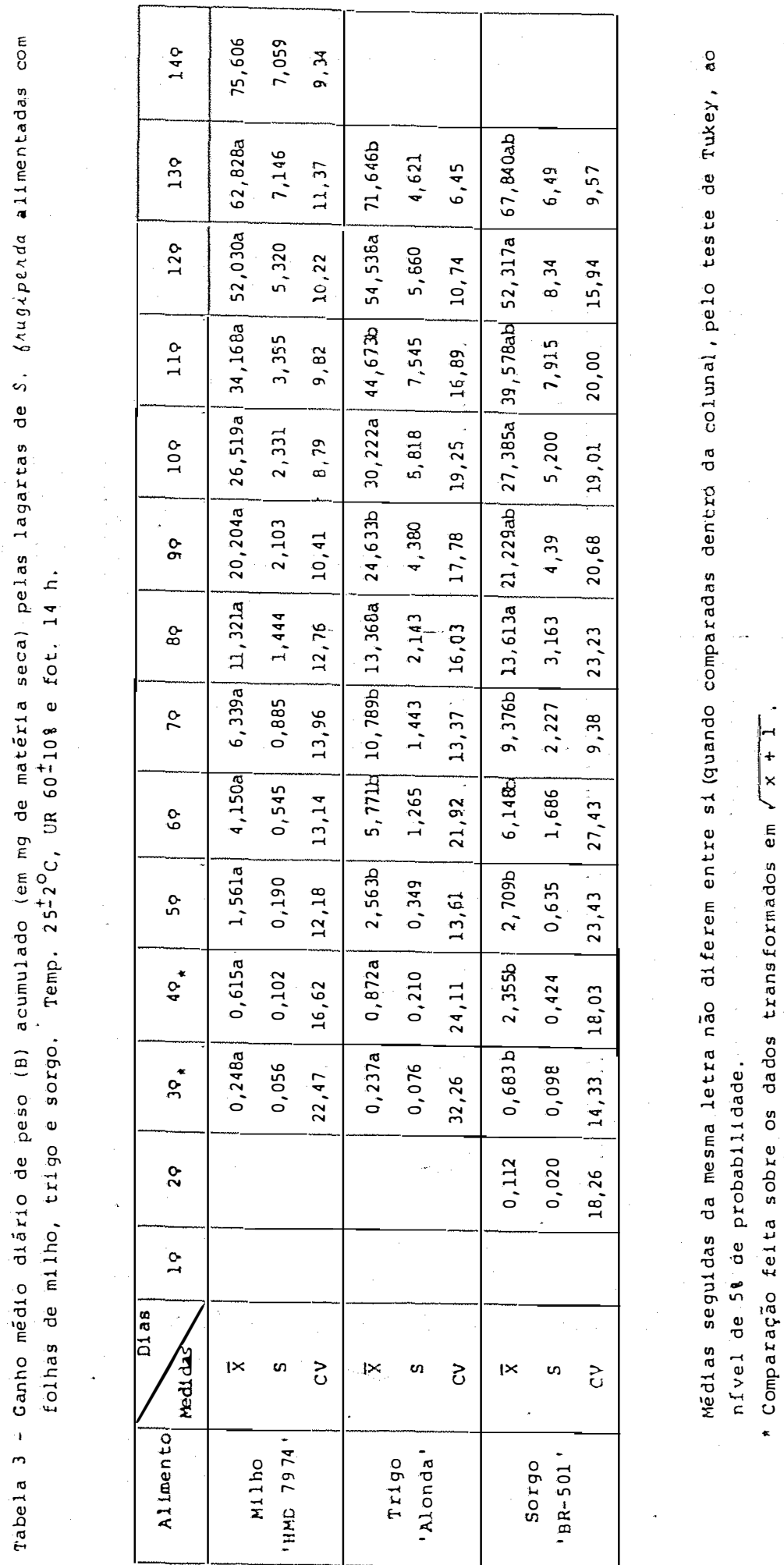


nas très gramíneas (Figura 4 ).

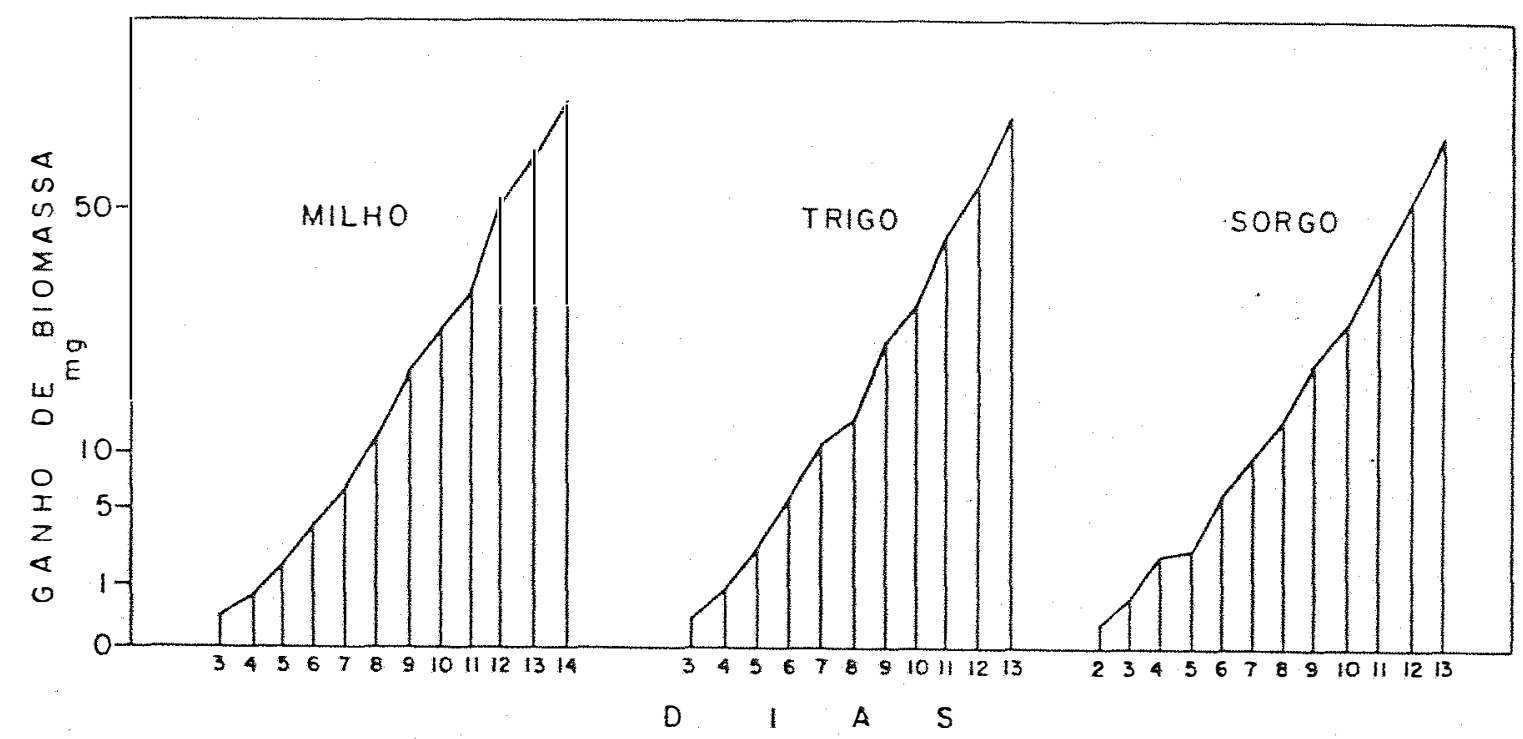

Eigura 4 - Ganho diārio àe biomassa (B) (em mg de matéria seca) pelas lagartas de $S$. frugiperda alimentadas com folhas de milho, trigo e sorgo. Temp. $25 \pm 2{ }^{\circ} \mathrm{C}$, UR $60 \pm 10 \%$ e fot. $14 \mathrm{~h}$. (Médias transformadas em $\sqrt{100 x}$.

Entretanto, a biomassa ganha durante toda a fa se larval foi maior para as lagartas que consumiram folhas de milho, menor para as alimentadas com folhas de sorgo e intermediária para as criadas sobre folhas de trigo. Observando-se a Tabela 3 e a Figura 4 percebe-se que essa relação definiuse no último dia larval, uma vez que no 12 o dia não havia diferenças significativas entre os tratamentos. Além disso, as lagartas criadas sobre milho apresentaram um ganho de biomassa maior que as outras, exatamente porque tiveram um dia a mais de alimentação.

Observando-se as Figuras 2,3 e 4 nota-se que nos 139 e 149 dias, o ganho de biomassa das lagartas alimentadas com folhas de milho não foi proporcional â quantidade de 
alimento ingerido e fezes produzidas, sendo o consumo grande, porém o ganho de peso relativamente pequeno. para as lagartas do trigo ocorreu o inverso, sendo o consumo grande no 12 a dia e pequeno no 139 e 0 ganho de biomassa pequeno no 129 dia e grande no 13\%. As lagartas em sorgo mantiveram a proporcionalidade nos últimos dias larvais. Observou-se que esse tipo de defasagem entre o consumo de alimento e o ganho de peso, assim como entre o consumo de alimento e a produção de fezes, ocorreu, várias vezes, ao longo do desenvolvimento larval (Ta belas 1, 2, 3 e Figuras 2, 3 e 4). Essa defasagem significa que a ingestão de alimentos de um dia geralmente é função da alimentação do período anterior, como se o inseto procurasse compensar, a cada dia, a quantidade insuficiente do alimento ingerido anteriormente.

4.3. Fndices e parámetros determinados

Os parâmetros e Índices calculados diariamente para a fase larval de $S$. frugiperda nos três hospedeiros são apresentados nas Tabelas 4 a 12, e nas Figuras 5 a 13, respec tivamente.

Como esses parâmetros e índices foram calculados sobre as médias acumuladas de ingestão de alimentos, produção de fezes e ganho de peso, apresentados nas Tabelas 1, 2 e 3, eles correspondem ao período compreendido entre a eclosão larval e o dia do cálculo. Portanto, não representam o ín dice dos dias indicados nas Tabelas e sim o índice do período desde a eclosão até esses dias. E, como foram calculados sobre as médias, não foram feitas comparações estatísticas entre as gramíneas hospedeiras.

\subsubsection{Alimento assimilado $(I-F)$}

Esse parâmetro representa a parcela do alimen- 
to ingerido que foi utilizada pelo inseto para conversão em biomassa e para metabolismo, sendo os resultados sumariados na Tabela 4 e Figura 5.

Até o 120 dia as lagartas alimentadas com folhas de sorgo assimilaram mais alimento, sendo que aquelas alimentadas com trigo apresentaram a menor assimilação até o 40 dia e, no período compreendido entre o 50 e 120 dias, assimilaram menos do que as criadas com folhas de sorgo e mais do que as de milho. Porém, no 139 dia o milho foi mais assimilado que o trigo, e este mais que o sorgo, de tal forma que a assimilação acumulada do milho igualou-se à do trigo e ambas ultrapassaram à do sorgo. Como as lagartas criadas em milho apresentaram um dia a mais de alimentação, a assimilação de toda fase larval foi maior neste hospedeiro. Por sua vez, as lagartas alimentadas com sorgo foram as que assimilaram menos alimento.

\subsubsection{Alimento metabolizado (M)}

Esse parâmetro proposto por SCRIBER e SLANSKY JR. (1981) representa a parte do alimento assimilado que foi utilizado na forma de energia para o metabolismo do inseto. Portanto, é a quantidade absoluta do alimento assimilado que não foi transformado em biomassa do inseto.

A parcela do alimento utilizado para o metabolismo das lagartas está apresentada na Tabela 5 e na Figura 6. Através da Figura 6 pode-se observar que a curva do alimeñto metabolizado apresentou-se irregular em relação às curvas de alimento ingerido e de alimento assimilado (Figuras 2 e 5). Isso significa que em determinados períodos de vida do inseto foi gasto mais alimento para o metabolismo e em outros foi gasto menos. Isso pode ter sido função de determinaàas características do alimento, como a presença de substâncias que provocaram consumo de energia para a anulação de seus efeitos 
sobre o inseto, ou da necessidade do inseto desviar energia para alguma função fisiológica que não resultou em crescimento.

Através da Tabela 5, nota-se que até o 120 dia as lagartas alimentadas com sorgo gastaram uma parcela maior do alimento em metabolismo do que as criadas sobre as outras gramíneas. Por outro lado, as lagartas mantidas em trigo gastaram menos, e as em milho, de um modo geral, apresentaram um gasto intermediārio.

Entretanto, observando-se a Figura 6 nota-se que, no 139 dia, as lagartas de trigo apresentaram uma redução no alimento metabolizado que correspondeu a uma redução semelhante na ingestão (Figura 2) porém, não observada na cur va de assimilação de alimento (Figura 5). As lagartas criadas sobre sorgo apresentaram, no 130 dia, uma queda no alimento metabolizado, que correspondeu a uma redução na ingestão (Figura 2), uma excreção relativamente grande (Figura 3) e uma assimilação reduzida (Figura 4 e Tabela 4). Isso significa que a excreção do sorgo ingerido deve ter sido mais lenta, aculando-se no trato digestivo do inseto e sendo eliminada somente no último dia de atividade larval. Isso pode ter ocorri do por causa de algum componente existente no sorgo que dificultou a sua digestão.

As lagartas criadas em milho apresentaram no 139 e 149 dias um incremento substancial no gasto de alimento em metabolismo, como se estivessem precisando de mais energia para passar para a fase seguinte. Entretanto, é interessante observar que as variações na ingestão e na assimilação do ali mento (Figuras 2 e 5) foram função da necessidade de gastos com o metabolismo, porque o ganho de peso (Tabela 3 e Figura 4) foi uniforme e relativamente próximo nas trēs gramineas.

Essas diferenças nas necessidades metabólicas 
ao longo do período larval explicam a defasagem entre o ganho de peso e o consumo de alimento comentados no item 4.2.3.

\subsubsection{Peso médio (E)}

De acordo com WALDBAUER (1964), esse parâmetro pode ser obtido através da integração da área sob a curva de crescimento, sendo que para curvas regulares e harmoniosas é possível obtê-lo calculando-se a média das pesagens diārias. Como o crescimento foi harmonioso (Figura 4), optou-se pelo cálculo através das pesagens diárias (Tabela 3).

A Tabela 6 e Figura 7 mostram que o peso médio $(\bar{B})$ foi, durante todo o ciclo larval, menor para as lagartas criadas em milho, intermediário para as alimentadas com sorgo e maior para as que consumiram trigo. Entretanto, o peso médio final foi maior para as lagartas criadas com folhas de mi lho, somente devido ao crescimento apresentado por elas no ūl timo dia de atividade alimentar.

\subsubsection{Taxa de consumo relativo (RCR)}

Esse Índice representa a quantidade de alimento ingerido por miligrama de peso corpóreo do inseto por dia, e é expresso em $\mathrm{mg} / \mathrm{mg}$. dìa.

Na Tabela 7 e Figura 8 estão apresentados os valores de RCR ao longo do desenvolvimento larval. Observouse que os insetos ingeriram relativamente mais no início do período larval, em seguida apresentaram uma queda, com oscila ções até o final da fase. A taxa relativamente alta, apresentada para o terceiro dia de atividade larval, quando foi iniciado o cálculo da RCR, pode ser conseqüência de uma imprecisão no cálculo do peso médio $(\overline{\mathrm{B}})$, pois, para esse dia somente se dispunha do peso inicial (que não sensibilizou a balança, portanto igual a zerol e da pesagem do 39 dia para seu cálcu- 
Tabela 4 - Alimento assimilado (I-F) acumulado (em mg de matéria seca) pelas lagartas de 5 . frugiperda alimentadas com folhas de milho, trigo e sorgo. Temp. $25 \pm 20 \mathrm{C}$, UR $60 \pm 108$ e Eotoperiodo i $4 \mathrm{~h}$.

\begin{tabular}{|c|c|c|c|c|c|c|c|c|c|c|c|c|c|c|}
\hline$\underbrace{\text { Dias }}_{\text {Alimento }}$ & 18 & 28 & 38 & 48 & 58 & 68 & 78 & 88 & 99 & 108 & 118 & 128 & 138 & 149 \\
\hline $\begin{array}{c}\text { Milho } \\
\text { "HAID } 7974 \text { " }\end{array}$ & - & - & 3,182 & 3,857 & 5,913 & 9,652 & 14,729 & 23,432 & 38,812 & 49,166 & 59,217 & 87,996 & 216,25 & 166,36 \\
\hline $\begin{array}{l}\text { Trígo } \\
\text { Alonda: }\end{array}$ & - & - & 1,882 & 3,105 & 6,318 & 30,276 & 15,906 & 21,895 & 43,700 & 50,567 & 65,603 & 92,976 & 116,22 & \\
\hline $\begin{array}{l}\text { Sorgo } \\
\text { BR-501: }\end{array}$ & - & - & 3,591 & 4,952 & 7,915 & 13,215 & 26,841 & 36,494 & 46,982 & 59,068 & 81,430 & 101,42 & 107,78 & \\
\hline
\end{tabular}

Tabela 5 - Alimento metabolizado (M) acumulado (em mg de matéria seca) pelas lagartas de $S$. frugiperda alimentadas com folhas de milho, trigo e sorgo. Temp. $25 \pm 2{ }^{\circ} \mathrm{C}$, UR $60 \pm 10 \%$ e fotoperiodo $14 \mathrm{~h}$.

\begin{tabular}{|c|c|c|c|c|c|c|c|c|c|c|c|c|c|c|}
\hline iimente Dias & 18 & 28 & 38 & 4.9 & 58 & 68 & 38 & 88 & 28 & 108 & 118 & 128 & 138 & 148 \\
\hline $\begin{array}{c}\text { Milho } \\
\text { HMD } 7974:\end{array}$ & $=$ & - & $\cdot 2,934$ & $.3,242$ & 4,352 & 5,502 & 8,380 & $12,11]$ & 18,615 & 22,647 & 25,049 & 35,966 & 53,422 & 90,750 \\
\hline $\begin{array}{l}\text { Trigo } \\
\text { 'Alonda! }\end{array}$ & - & - & 1,645 & 2,233 & 3,755 & 4,505 & 5,117 & 8,527 & 19,067 & 20,345 & 20,921 & 38,438 & 44,650 & \\
\hline $\begin{array}{l}\text { Sorgo } \\
\text { BR-501 }\end{array}$ & - & - & 2,908 & 2,597 & 5,206 & 7,067 & 17,465 & 22,881 & 25,753 & 31,683 & 41,852 & 49,103 & 39,940 & \\
\hline
\end{tabular}

Tabela 6 - Peso médio $(\bar{B})$ diārio acumulado lem mg de matéria secal das lagartas de $S$. frugiperda alimentadas com folhas de milho, trigo e sorgo. Temp. $25 \pm 2{ }^{\circ} \mathrm{C}$, UR $60 \pm 108$ e fotop. $14 \mathrm{~h}$.

\begin{tabular}{|c|c|c|c|c|c|c|c|c|c|c|c|c|c|c|}
\hline$\underbrace{\text { Dias }}_{\text {Alimento }}$ & 18 & 28 & 38 & 48 & 58 & 68 & 78 & 88 & 98 & 108 & 118 & 128 & 138 & 148 \\
\hline $\begin{array}{c}M 1 \text { ho } \\
\text { 'HMD } 7974 \text { ' }\end{array}$ & - & - & 0,124 & 0,431 & 0,808 & 1,640 & 2,583 & 4,039 & 6,348 & 8,870 & 11,680 & 15,715 & 19,998 & 24,400 \\
\hline $\begin{array}{l}\text { Trigo } \\
\text { Alonda. }\end{array}$ & - & - & 0,118 & 0,554 & 1,224 & 2,361 & 4,046 & 5,600 & 8,319 & 11,057 & 14,792 & 18,767 & 23,580 & \\
\hline $\begin{array}{l}\text { Sorgo } \\
\text { 'BR-501. }\end{array}$ & - & 0,056 & 0,375 & 1,035 & 1,453 & 2,392 & 3,556 & 4,996 & 7,025 & 9,287 & 12,316 & 15,952 & 20,240 & \\
\hline
\end{tabular}


47.

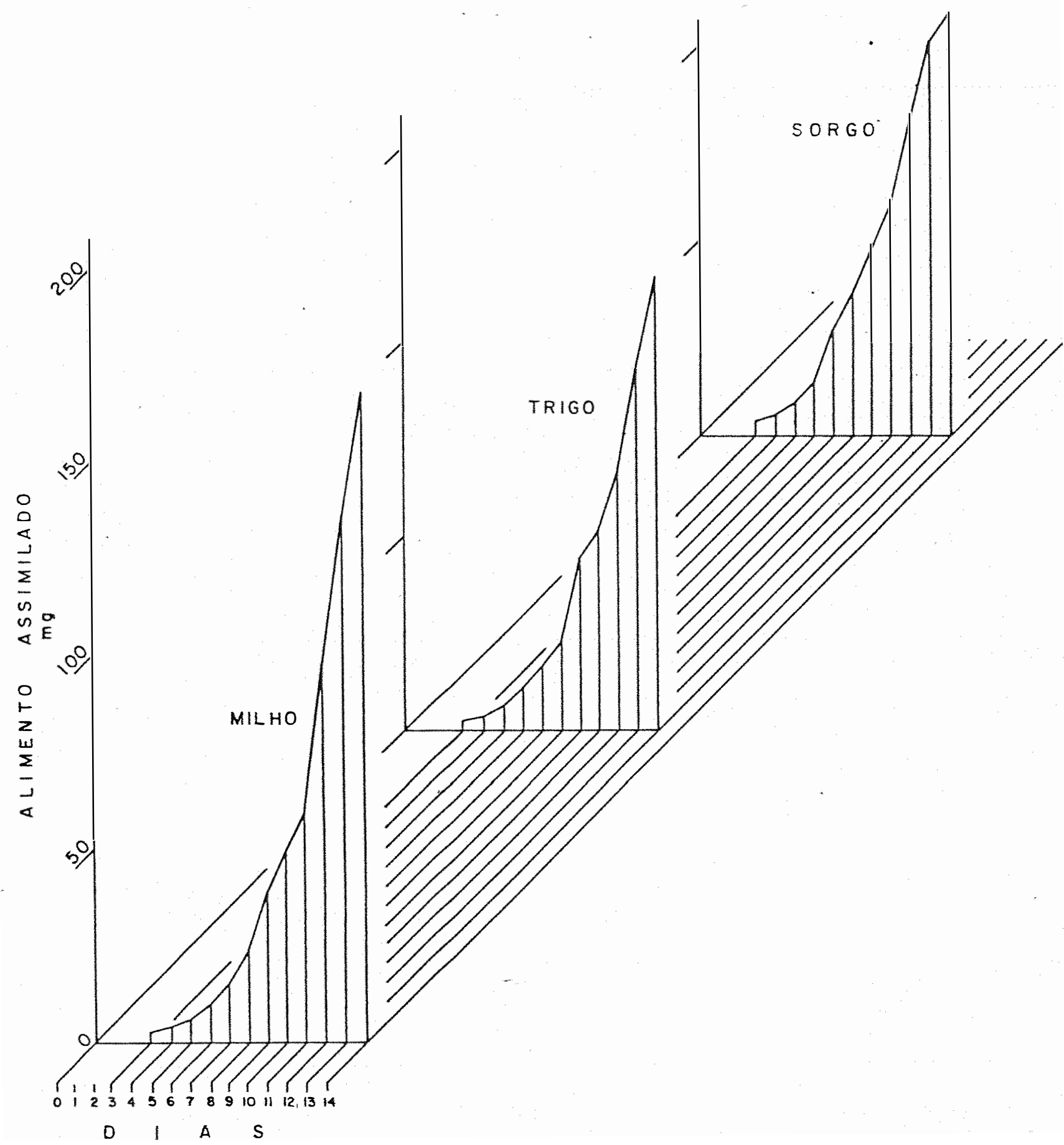

Figura 5 - Alimento assimilado (I-F) (em mg de matéria seca) pelas lagartas de $S$. frugiperda alimentadas com fo lhas de milho, trigo e sorgo. Temp. $25 \pm 2^{\circ} \mathrm{C}$, UR $60 \pm 10 \%$ e fot. $14 \mathrm{~h}$. 


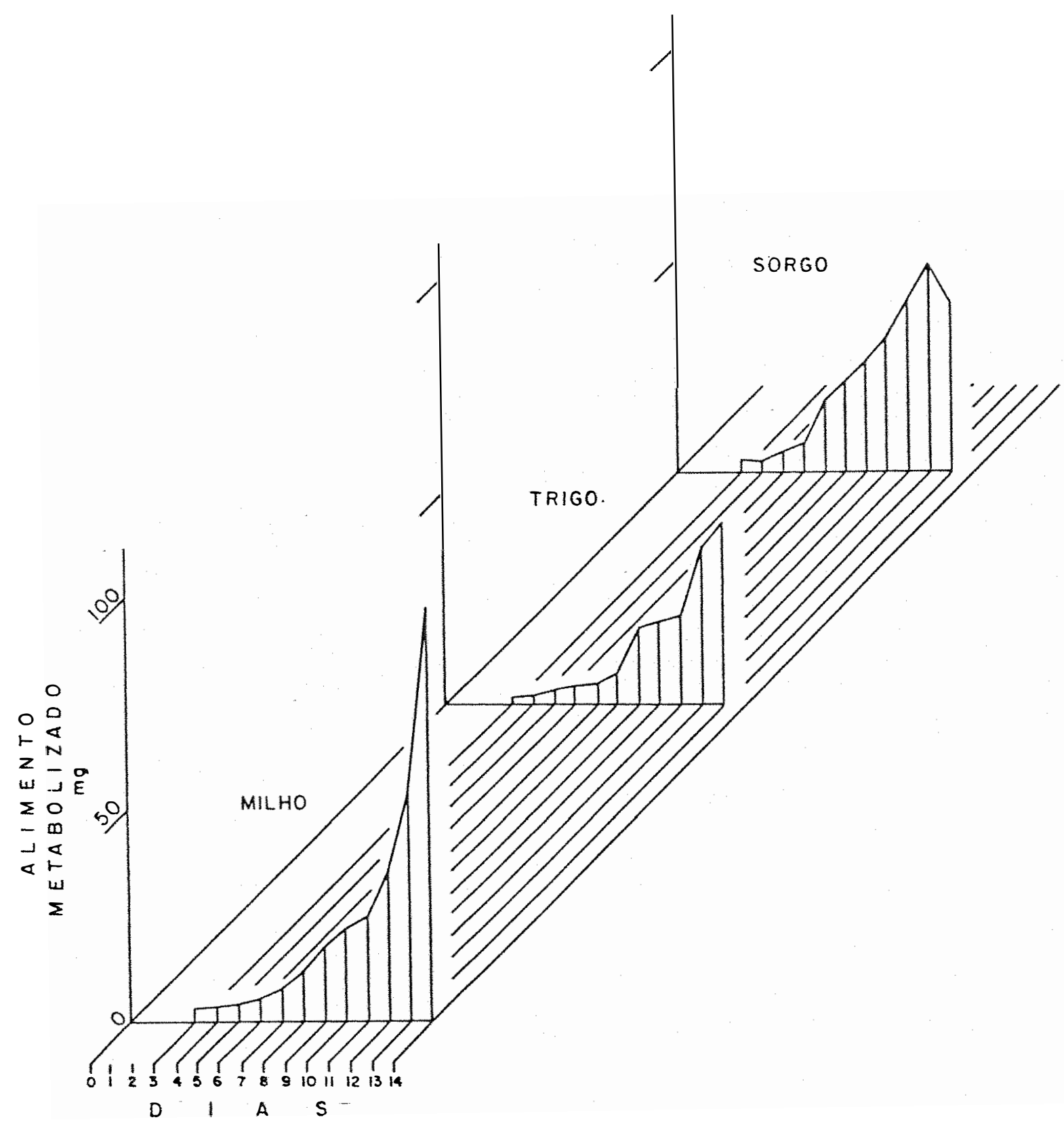

Figura 6 - Plimento metabolizado (M) (em mg de matéria seca) pelas lagartas de $S$. frugiperda alimentadas com fo Ihas de milho, trigo e sorgo. Temp. $25^{ \pm}-2^{\circ} \mathrm{C}$, UR $60 \pm 10 \%$ fot. $14 \mathrm{~h}$. 


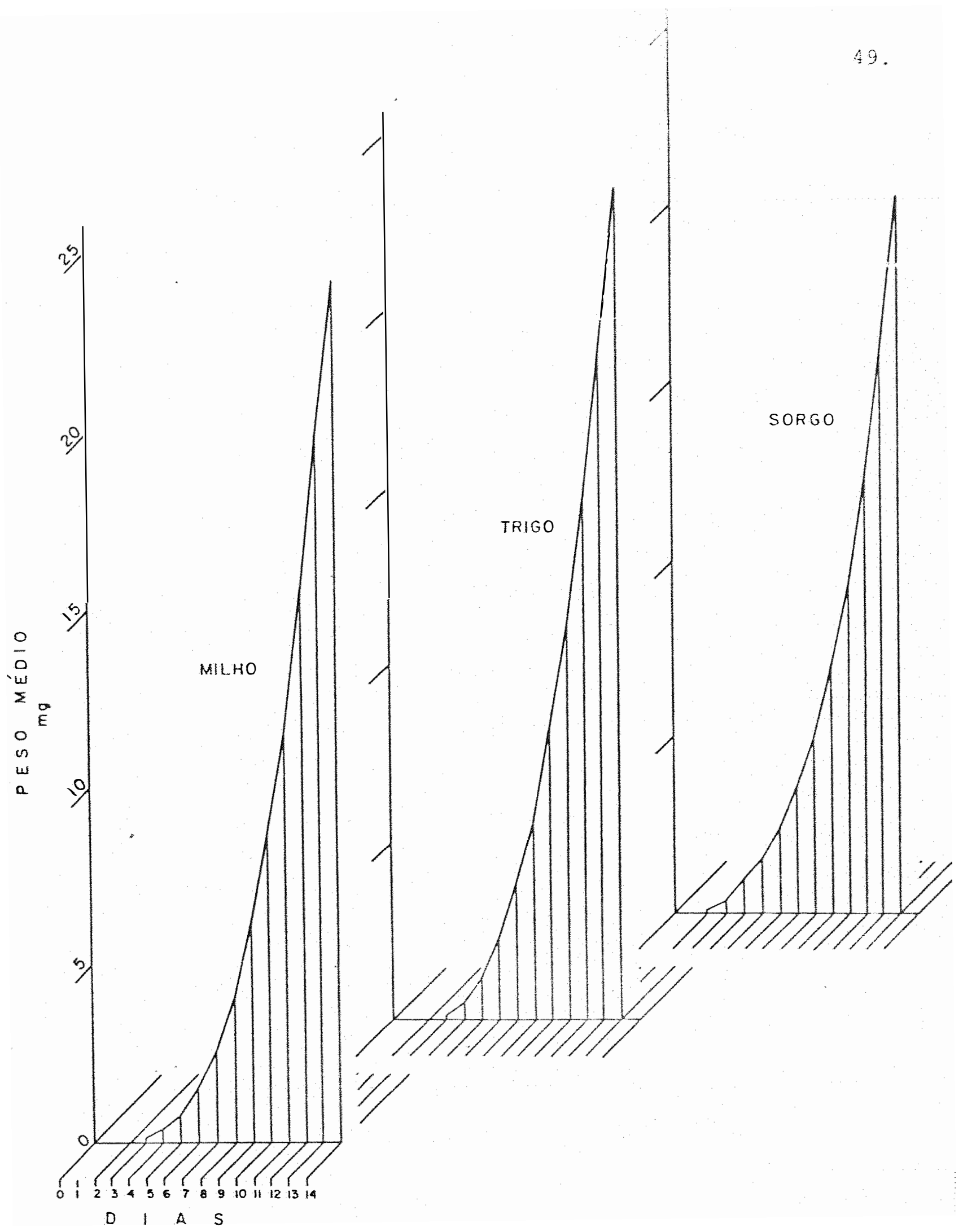

Figura 7 - peso médio diário (E). (em mg de matéria seca) das lagartas de $S$. frugiperda alimentadas com folhas de milho, trigo e sorgo. Temp. $25 \pm 2^{\circ} \mathrm{C}, \angle R 60 \pm 10 \%$ e fot. $14 \mathrm{~h}$. 
10. Nos dias que se seguiram foi possível uma estimativa mais acurada do peso médio $(\bar{B})$, pois o nūmero de dados aumen tou com o passar do tempo. Esta, no entanto, é a tendência ob servada para outros insetos, porque no início o inseto necessita de muito alimento para o crescimento (VENDRAMIM, 1982, CARVALHO, 1981).

No final do período larval, as lagartas criadas em milho apresentaram um aumento na RCR enquanto que as criadas em trigo e em sorgo apresentaram uma queda. Isso significa que aquelas mantidas em milho realmente intensificaram a ingestão de alimentos no final da fase larval. Devido a esse aumento, elas passaram a apresentar a RCR geral maior do que as alimentadas com sorgo, que vinham mantendo durante todo o desenvolvimento larval uma RCR mais elevada. Por outro lado, as alimentadas com trigo apresentaram a RCR menor durante toda a fase larval.

\subsubsection{Taxa metabólica relativa (RMR)}

Esse Indice representa a quantidade de alimento gasto em metabolismo por miligrama de peso corpóreo biomas sa do inseto por dial, e é expresso em mg/mg.dia.

Os valores da RMR estão apresentados na Tabela 8 e Figura 9.

A RMR àas lagartas que se alimentaram de milho decresceu com o desenvolvimento larval até o penúltimo dia, quando apresentou um pequeno aumento; em trigo houve a mesma tendência porém, com valores menores. As lagartas que consumi ram folhas de sorgo apresentaram oscilações até o 7ọ dia, quando então a RMR passou a decrescer até o ūltimo dia e não apresentaram o pequeno incremento observado nos outros grupos. Com exceção dos 4 primeiros dias de vida, as lagartas álimentadas com folhas de sorgo apresentaram a RMR maior. Entre 
tanto, em termos gerais, as lagartas alimentadas com folhas de mitho apresentaram a maior RMR e as criadas em trigo a menor.

A RMR inicial, relativamente menor, apresentada pelas lagartas alimentadas com folhas de sorgo, significa que, ao iniciar a alimentação, o material assimilado era mais facilmente convertido em biomassa do inseto do que o milho ou o trigo. Porém, com o desenvolvimento larval, provavelmente, alguma toxina foi acumulando-se no organismo, exigindo mais tarde um consumo maior de energia para a sua desintoxicação. Entretanto, a queda acentuada da RMR no último dia de ativida de das lagartas significa que os insetos alimentados com sorgo apresentaram uma exigência menor de energia para a pupação, ou então conseguiram desenvolver uma habilidade para metaboli zar melhor o alimento ingerido.

\subsubsection{Taxa de crescimento relativo (RGR).}

A taxa de crescimento relativo indica o ganho de biomassa pelo inseto em relação a seu peso e é expressa em $\mathrm{mg} / \mathrm{mg}$. dia. Os valores de $R G R$ estão apresentados na Tabela 9 e Figura 10 .

Excetuando-se algumas oscilações na RGR podese considerar que, de uma maneira geral, esse índice apresentou-se semelhante nas três gramíneas, tanto em valor como em tenđência. As oscilações da RGR, foram compensatórias, isto é, quando caía demais num dia ela apresentava uma elevação no dia seguinte, ou quando permanecia 2 dias com o mesmo valor ela apresentava um decréscimo maior no dia seguinte (Figura 101 .

E interessante observar que, no início, as lagar tas apresentaram um crescimento maior no sorgo, porém, no 59 dia elas apresentaram uma queda passando a ter um desenvolvimento semelhante ao das lagartas alimentadas nas outras gramí 
Tabela 7 - Taxa de consumo relativo (RCRl das lagartas de S', frugipenda allmentadas com folhas de milho, trigo e sorgo. Tem, $25 \pm 2{ }^{\circ} \mathrm{C}$, uR $60 \pm 10$ e fot. $14 \mathrm{~h}$,

\begin{tabular}{|c|c|c|c|c|c|c|c|c|c|c|c|c|c|c|}
\hline Al1mento & 18 & 28 & 39 & 49 & 58 & 68 & 78 & $B 9$ & 9.8 & 109 & 118 & 128 & 238 & 148 \\
\hline $\begin{array}{c}\text { M1 lho } \\
\text { 'HMD } 7974 \text { ' }\end{array}$ & - & - & 9,475 & 2,685 & 2,120 & 1,733 & 1,573 & 1,541 & 1,463 & 1,330 & 1,136 & 1,200 & 1,253 & 1,336 \\
\hline $\begin{array}{l}\text { Trigo } \\
\text { 'Alonca. }\end{array}$ & - & - & 5,706 & 1,620 & 1,332 & 1,023 & 0,944 & 0,836 & 2,018 & 0,890 & 0,916 & 0,992 & 0,883 & \\
\hline $\begin{array}{l}\text { Sorgo } \\
\text { 'BI-501: }\end{array}$ & - & - & 3,902 & 2,157 & 1,796 & 1,917 & 1,857 & 1,712 & 1,537 & 1,363 & 1,357 & 1,343 & 1,162 & \\
\hline
\end{tabular}

Tabela 8 - Taxa metabóllca relativa (RMR) das lagartas de $S$, Grugipenda allmentadas com folhas de milho, trigo e sorgo. Temp, $25 \pm 2{ }^{\circ} \mathrm{C}$, OR $60^{ \pm} \pm 10$ e fot, $14 \mathrm{~b}$.

\begin{tabular}{|c|c|c|c|c|c|c|c|c|c|c|c|c|c|c|}
\hline Al1mento & 18 & 28 & 38 & 49 & 58 & 68 & 78 & 89 & 28 & 108 & 118 & 128 & 138 & 148 \\
\hline $\begin{array}{c}\text { M1 lho } \\
\text { HMD } 7974 .\end{array}$ & - & - & 7,887 & 1,878 & 1,077 & 0,559 & 0,463 & 0,375 & 0,326 & 0,255 & 0,195 & 0,191 & 0,205 & 0,266 \\
\hline $\begin{array}{l}\text { Tr1go } \\
\text { Alonda: }\end{array}$ & - & - & 4,627 & 1,007 & 0,613 & 0,318 & 0,181 & 0,190 & 0,255 & 0,184 & 0,128 & 0,171 & 0,145 & \\
\hline $\begin{array}{l}\text { Sorgo } \\
\text { 'BR-501: }\end{array}$ & - & - & 2,585 & 0,627 & 0,316 & 0,492 & 0,702 & 0,573 & 0,407 & 0,342 & 0,309 & 0,257 & 0,152 & \\
\hline
\end{tabular}

Tabela 9 - Taxa de cresclmento relativo (RGRl das lagartas de S. frugipenda allmentadas com folhas de.milho, trigo e soIgo. Terp. $25 \pm 2{ }^{\circ} \mathrm{C}$, UR $60 \pm 10 \mathrm{e}$ fot. $14 \mathrm{~h}$.

\begin{tabular}{|c|c|c|c|c|c|c|c|c|c|c|c|c|c|c|}
\hline Alimento & 18 & 28 & 39 & 48 & 58 & 68 & 78 & 89 & 98 & 108 & 118 & 128 & 139 & 149 \\
\hline $\begin{array}{c}\text { M1 lho } \\
\text { HMD } 7974^{\circ}\end{array}$ & - & - & 0,667 & 0,356 & 0,386 & 0,422 & 0,351 & 0,350 & 0,354 & 0,299 & 0,266 & 0,276 & 0,242 & 0,221 \\
\hline $\begin{array}{l}\text { Trigo } \\
\text { A.londa: }\end{array}$ & - & - & 0,667 & 0,393 & 0,419 & 0,407 & 0,381 & 0,298 & 0,329 & 0,273 & 0,274 & 0,242 & 0,234 & \\
\hline $\begin{array}{l}\text { Sorgo } \\
\text { BI-501! }\end{array}$ & - & - & 0,607 & 0,569 & 0,373 & 0,428 & 0,377 & 0,341 & 0,336 & 0,295 & 0,292 & 0,273 & 0,258 & \\
\hline
\end{tabular}


53.

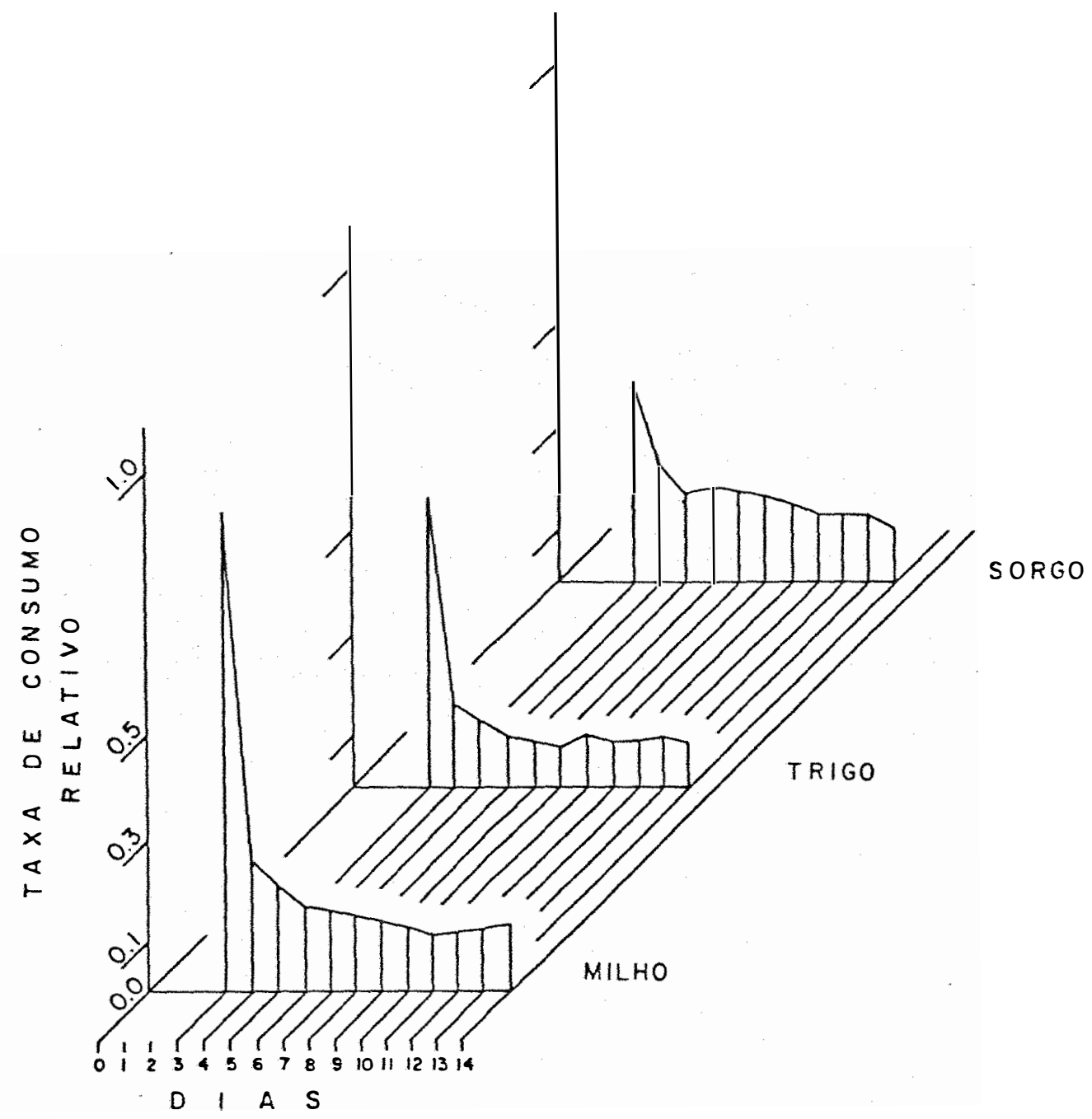

Figura 8 - Taxa de consumo relativo (RCR) das lagartas de $S$. brugiperda alimentadas com folhas de milho, trigo e sorgo. Temp. $25 \pm 2^{\circ} \mathrm{C}$, UR $60^{ \pm} 10 \%$ e fot. $14 \mathrm{~h}$. 


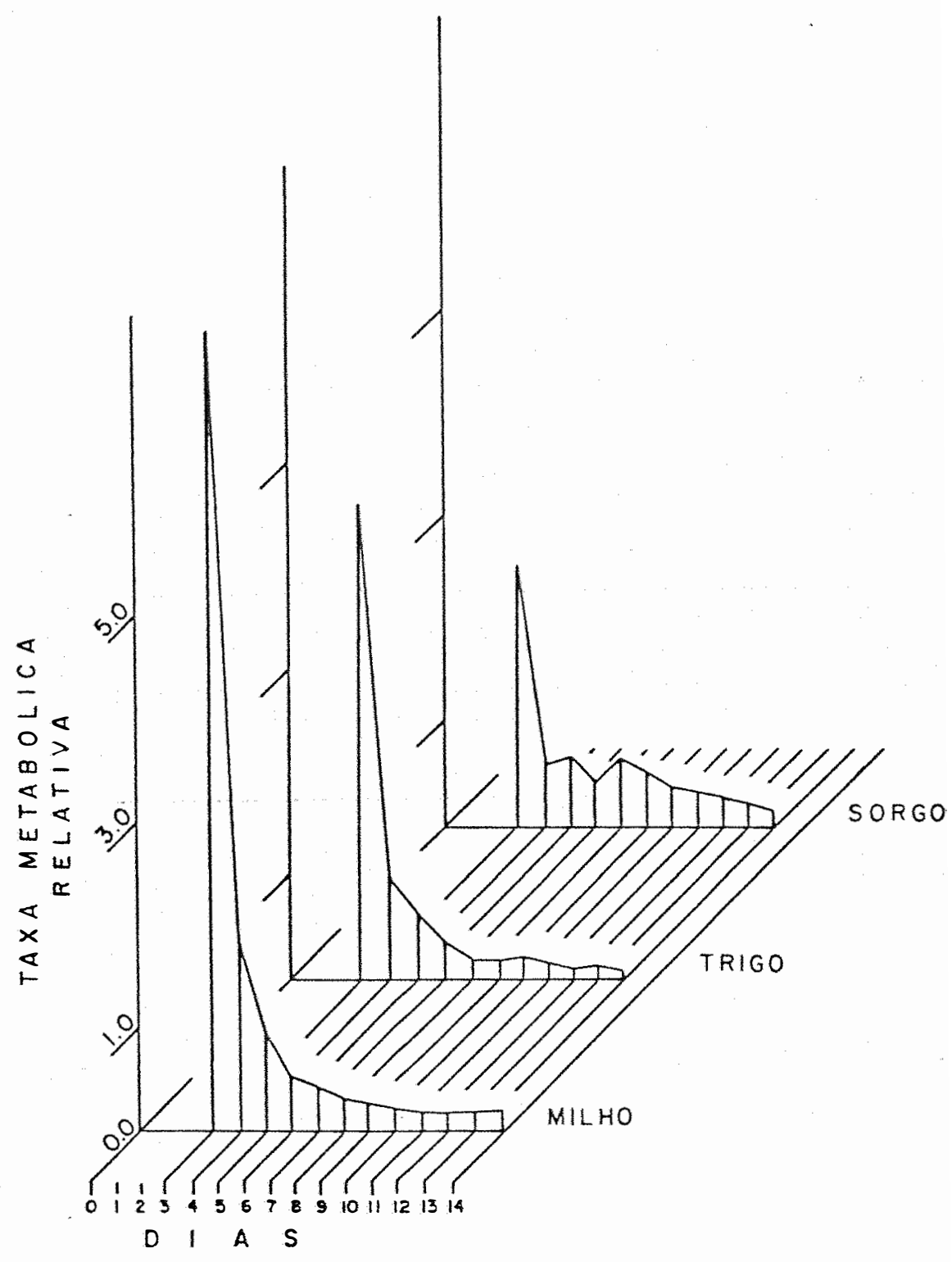

Figura 9 - Taxa metabólica relativa (RMR) das lagartas de $S$. Grugiperda alimentadas com folhas de milho, trigo e sorgo. Temp. $25 \pm 2^{\circ} \mathrm{C}$, UR $60 \pm 10 \% \mathrm{e}$ fot. $14 \mathrm{~h}$. 
55.

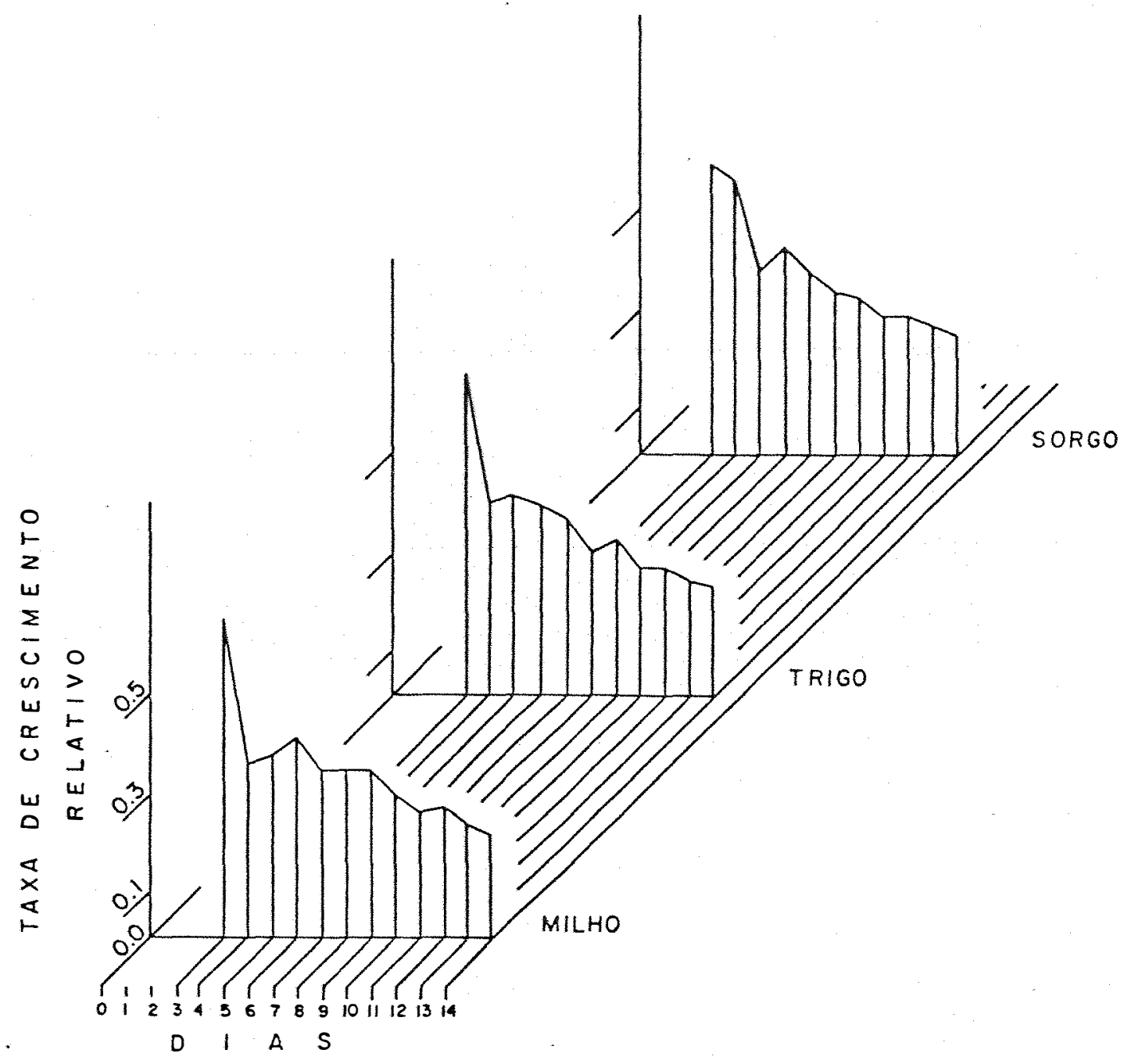

Figura 10 - Taxa de crescimento relativo (RGR) das lagartas de $S$. frugiperda alimentadas com folhas de milho, trigo e sorgo. Temp. $25 \pm 2^{\circ} \mathrm{C}$, UR $60 \pm 10 \%$ e fot. 14 h. 
neas. Comparando-se as Figuras 8,9 e 10 , nota-se que até o 49 dia o sorgo, apresentou uma RCR menor que as outras gramíneas, uma RMR também menor e uma RGR maior. Isso vem confirmar a observação feita para o RMR (item 4.3.5.) demonstrando que nos 4 primeiros dias o custo metabólico do sorgo foi menor que o do milho ou do trigo.

A comparação das Figuras 8, 2. e 10 também permite observar que as diferentes RCR das três gramíneas foi mais uma função do custo metabólico do alimento do que das ne cessidades de crescimento do inseto. Assim, é possível que os insetos tenham apresentado uma capacidade de compensar as diferenças entre os hospedeiros testados para manter o desenvol vimento normal.

4.3.7. Eficiência de conversão do alimento ingerido (ECI).

Esse índice representa a percentagem do alimen to ingerido pelo inseto que é transformado em biomassa, e es tá apresentado na Tabela 10 e Figura 11.

A ECI se apresentou diferente em valor e tendência para cada uma das gramíneas estudadas. No milho, a ECI foi baixa no início, e cresceu até o 69 dia, quando permaneœu aproximadamente constante até o 129 dia, para então iniciar uma queda até o último dia. No trigo, a ECI também foi baixa no início e cresceu até o 69 dia, quando iniciou uma queda acentuada até o l2: dia, e teve uma pequena elevação no último dia. No sorgo, a ECI iniciou-se baixa, cresceu até o 4 ? dia, e a partir do 50 dia permaneceu praticamente constante até o final, quando apresentou uma pequena elevação.

Até o 49 dia, a ECI do sorgo foi maior que a do trigo e esta, maior que a do milho. A partir do 7o dia, a ECI do sorgo tornou-se menor que a do milho, permanecendo assim até o 129 dia, quando as lagartas apresentaram uma queda acen 
tuada na ECI do milho que se tornou inferior a do sorgo. Entretanto, a partir do 50 dia a ECI do trigo foi maior do que às das outras gramíneas.

Isso significa que durante os 5 primeiros dias de vida as lagartas criadas com sorgo converteram mais alimen to em energia para o metabolismo e em biomassa do que as outras. A partir do 70 dia as lagartas alimentaäas com trigo tornaram-se mais eficientes. E, as lagartas criadas em milho, tiveram a ECI reduzida nos 2 últimos dias larvais exatamente porque apresentaram um consumo elevado nesses dois dias (Tabe la 1, Figura 2). Isso pode ser conseqüência cia necessidade de algum nutriente específico para as lagartas próximas à pupação, o qual deveria estar presente em pequena quantidade no milho.

4.3.8. Digestibilidade aproximada (AD)

Esse indice representa a percentagem do alimen to ingerido que é efetivamente assimilado pelo inseto.

Os dados apresentados na Tabela ll e Figura 12 são de digestibilidade aproximada (AD) porque não foi conside rada a excreção de urina pelos insetos. Porém, como se trata de um inseto fitófago, se alimentanāo sobre folhas que normal mente apresentam um teor relativamente baixo de proteína, pode-se considerar que esses dados se aproximam bastante da digestibilidade aparente, porque suas fezes contêm pouca urina (WALDBAUER, 19681 .

De uma maneira geral, a áigestibilidade das três gramíneas foi alta no início da fase larval, caindo cons tantemente até o final. Porém, tanto as lagartas criadas em milho, como as criaảas em trigo, apresentaram um leve aumento da $A D$ no último dia larval. As lagartas alimentadas com folhas de sorgo apresentaram no 49 e 60 dias, valores menores que o esperado provocando uma oscilação na curva da Figura 12. 
Essa oscilação teve uma correspondência direta com oscilação da RMR (Figura 9) e inversa com oscilações da RCR e da RGR (Figura 8 e 10). Também, a curva de ECI (Figura 11) apresentou no 4o dia, um pico diferente das outras gramíneas. Isso indica que nesse período as lagartas que se alimentavam de sorgo sofreram algum distúrbio que prejudicou a utilização do alimento.

A digestibilidade das folhas de milho foi maior que a do sorgo até o 69 dia e menor do 79 ao 130 dia, elevando-se no 149, quando se tornou levemente maior. Porém, a $\mathrm{AD}$ das folhas de trigo foi maior que a cas outras duas gramíneas durante toda a fase larval.

\subsubsection{Eficiéncia de conversão do alimento digerido - (ECD)}

A eficiência de conversão do alimento digerido (ECD) representa a porcentagem do alimento digerido que é con vertido em biomassa do inseto, e o seu inverso (100-ECD) indi ca a percentagem de alimento metabolizado em energia (custo metabólicol, para a manutenção da vida.

Os valores da ECD são apresentados na Tabela 12 e na Figura 13. Entre 50 e 0 129 dia a ECD do trigo foi a maior. Durante os 7 primeiros dias ela cresceu de forma constante, e em seguida passou a oscilar em torno de um valor médio até o final da fase larval. A ECD do milho, com exceção do 129 dia, foi sempre menor que a do trigo. Ela foi crescente até o 129 dia quando então iniciou uma queda acentuada até - final da fase larval. A ECD do sorgo foi maior do que a das outras gramíneas do início da fase larval até o 40 dia, e em seguida oscilou até o 7\%. Com as oscilações do 59 ao 79 dia ela assumiu um valor bem abaixo da ECD das outras gramíneas. A partir do 89 dia ela começou crescer de forma constante até o último quando se tornou maior do que as outras. 
Os insetos que se alimentaram de milho gasta ram mais para produzir energia metabólica durante toda a fase larval e ainda necessitaram de mais energia nos dois últimos dias, para realizar a transformação para a fase seguinte. Os insetos alimentados com folhas de sorgo, iniciaram o desenvol vimento com baixo custo metabólico, porém após 4 dias passaram a ter dificuldades de utilização do alimento. Entretanto, desenvolveram um mecanismo de utilização co alimento que permitiu que o custo metabólico nesse grupo se tomasse cada vez menor.

A elevação do custo metabólico apresentada pelos insetos criados em sorgo a partir do 50 dia, assim como a do final da fase larval dos insetos criados em milho, pode ser atribuída à presença de determinadas substâncias no alimento que afetaram a fisiologia do inseto (SCRIBER e SLANSKY JR., 1981). No caso do sorgo, como o inseto se encontrava ainda no início da fase larval, foi possível o desenvolvimento de meca nismos fisiológicos que the permitisse manter a performance de crescimento (Tabela 3 e Figura 4). No caso do milho, como o processo ocorreu no final da fase larval, não houve tempo para recuperação e o inseto manteve a performance de crescimento (Tabela 3, Figura 4L, ingerindo mais alimento (Tabela 1 , Figura 2).

O gasto de parte do alimento absorvido também pode ser conseqüência do valor nutricional do alimento, como por exemplo a deficiência de algum nutriente essencial (WALDBAUER, 19681.. Essa hipótese poderia explicar o caso do milho, sobre o qual as lagartas apresentaram um aumento do custo metabólico apenas nos 2 últimos dias, quando podem ter exigido algum nutriente específico para a pupação, o qual deveria existir em quantidade insuficiente. No caso do sorgo, essa hi pótese pode ser afastada porque a deficiência nutricional afe taria a fase larval toda, e não apenas um curto período. Além disso, dificilmente o inseto se adaptaria à falta de algum nu 
Tabela 10 - Eflcléncla de conversão do alimento ingerido (ECI) pelas lagartas de $S$. frugiperda cria das sobre folbas de milbo, trigo e sorgo. Temp. $25 \pm 2{ }^{\circ} \mathrm{C}$, UR $60 \pm 108$ e fot. $14 \mathrm{~b}$.

\begin{tabular}{|c|c|c|c|c|c|c|c|c|c|c|c|c|c|c|}
\hline mento & 18 & 29 & 38 & 48 & 58 & 69 & 78 & 88 & 98 & 108 & 128 & 128 & 138 & 148 \\
\hline $\begin{array}{c}\text { M1 ho } \\
\text { 'HMD } 7974 .\end{array}$ & $=$ & - & 7,03 & 13,27 & 18,22 & 24,33 & 22,29 & 22,73 & 24,18 & 22,46 & 23,40 & 23,00 & 19,29 & 16,57 \\
\hline $\begin{array}{l}\text { Trigo } \\
\text { Alonda' }\end{array}$ & - & - & 11,73 & 24,27 & 31,44 & 39,83 & 40,37 & 35,69 & 32,32 & 30,70 & 29,99 & 24,23 & 26,46 & \\
\hline $\begin{array}{c}\text { Sorgo } \\
\text { BR-501: }\end{array}$ & - & 5,63 & 15,56 & 26,37 & 20,75 & 22,34 & 20,28 & 19,89 & 21,85 & 21,63 & 21,30 & 20,34 & 22,18 & \\
\hline
\end{tabular}

Tabela 11 - Digestibil1dade aproximada (AD) das folbas de milbo, trigo e sorgo para as lagartas de s. frugiperda. Temp. $25 \pm 2{ }^{\circ} \mathrm{C}$, UR $60 \pm 108$ e fot. $14 \mathrm{~h}$.

\begin{tabular}{|l|c|c|c|c|c|c|c|c|c|c|c|c|c|c|}
\hline Alimento & 18 & 28 & 39 & 48 & 58 & 69 & 78 & 89 & 98 & 108 & 118 & 129 & 139 & 149 \\
\hline $\begin{array}{c}\text { Milho } \\
\text { MMD } 7974\end{array}$ & - & - & 90,26 & 83,21 & 69,03 & 57,83 & 51,77 & 47,0 & 46,45 & 41,64 & 40,56 & 38,89 & 35,69 & 36,46 \\
\hline $\begin{array}{c}\text { Tr1go } \\
\text { Alonda' }\end{array}$ & - & - & 93,17 & 86,42 & 77,49 & 70,92 & 59,51 & 58,46 & 57,34 & 51,36 & 44,03 & 41,30 & 42,90 & \\
\hline $\begin{array}{c}\text { Sorgo } \\
\text { BR-501. }\end{array}$ & - & - & 81,80 & 55,45 & 60,62 & 48,01 & 58,07 & 53,32 & 48,36 & 46,66 & 43,81 & 39,43 & 35,24 & \\
\hline
\end{tabular}

Tabela 12 - Eflcléncla de conversão do al1mento digerlodo (ECDl pelas lagartas de S. frugiperda alimentadas com folhas de milho, trigo e sorgo, Temp. $25 \div 2{ }^{\circ} \mathrm{C}$, UR $60 \pm 108$ e fot. $14 \mathrm{~b}$

\begin{tabular}{|c|c|c|c|c|c|c|c|c|c|c|c|c|c|c|}
\hline Dias & 18 & 28 & 38 & 48 & 58 & 68 & 78 & 88 & 98 & 108 & 118 & 128 & 138 & 148 \\
\hline $\begin{array}{l}\text { Mil lho } \\
\text { 'HMD } 79.74^{\circ}\end{array}$ & & & 7,79 & 15,94 & 26,39 & 42,07 & 43,06 & 48,36 & 52,06 & 53,94 & 57,69 & 59,14 & 54,05 & 45,44 \\
\hline $\begin{array}{l}\text { Trigo } \\
\text { 'Alonda! }\end{array}$ & & & 12,60 & 28,08 & 41,86 & 56,16 & 67,83 & 61,05 & 56,36 & 59,77 & 68,11 & 58,67 & 61,65 & \\
\hline $\begin{array}{l}\text { Sorgo } \\
\text { 'BR-501: }\end{array}$ & & & 19,02 & 47,56 & 34,23 & 46,53 & 34,92 & 37,30 & 45,18 & 45,56 & 48,62 & 51,58 & 62,94 & \\
\hline
\end{tabular}




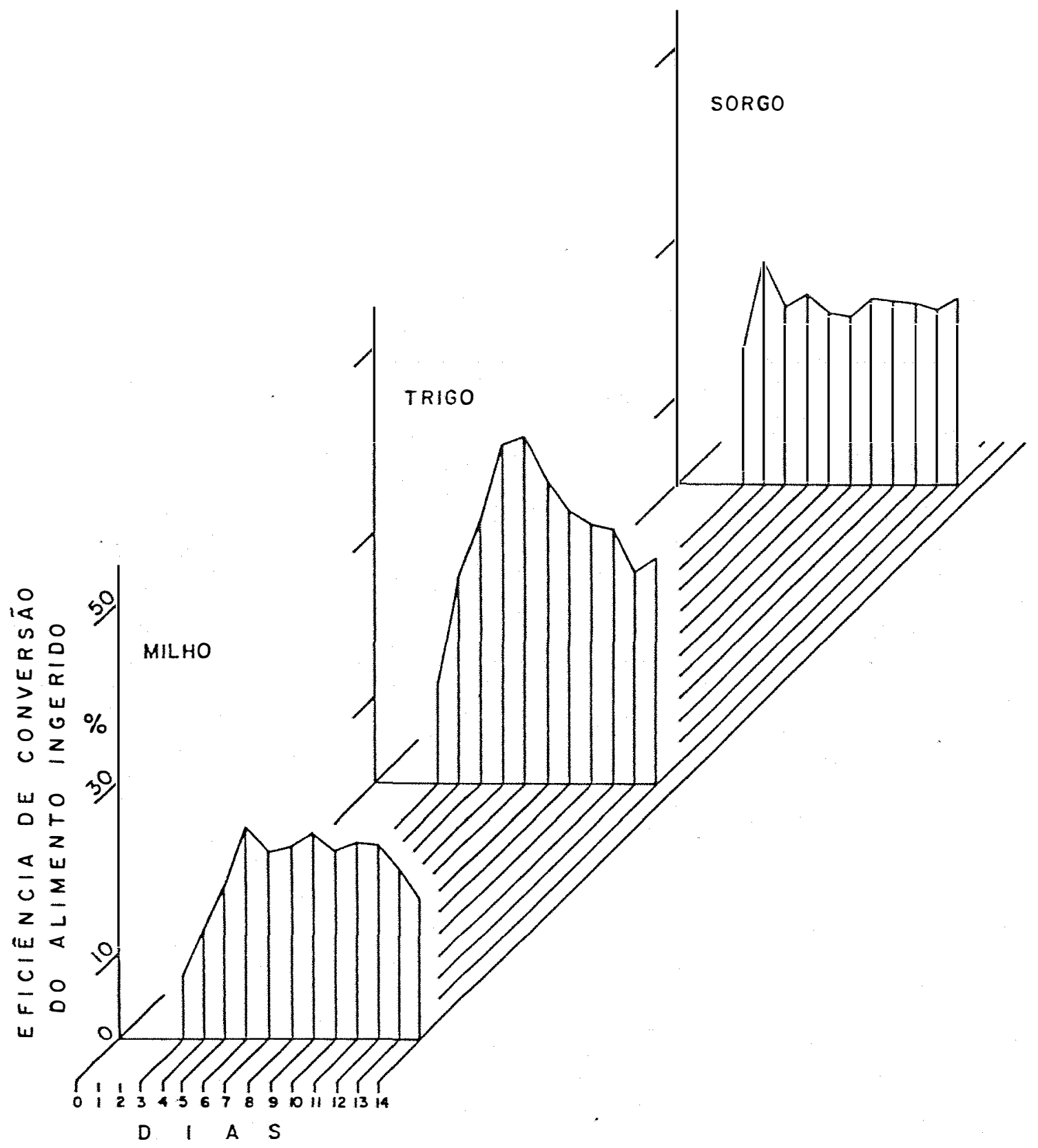

Figura 11 - Eficiência de conversão do alimento ingerido (ECI) pelas lagartas de $S$. frugiperda alimentadas com folhas de milho, trigo e sorgo. Temp. $25 \pm 2{ }^{\circ} \mathrm{C}$, UR $60 \pm 10 \%$ e fot. $14 \mathrm{~h}$. 
62.

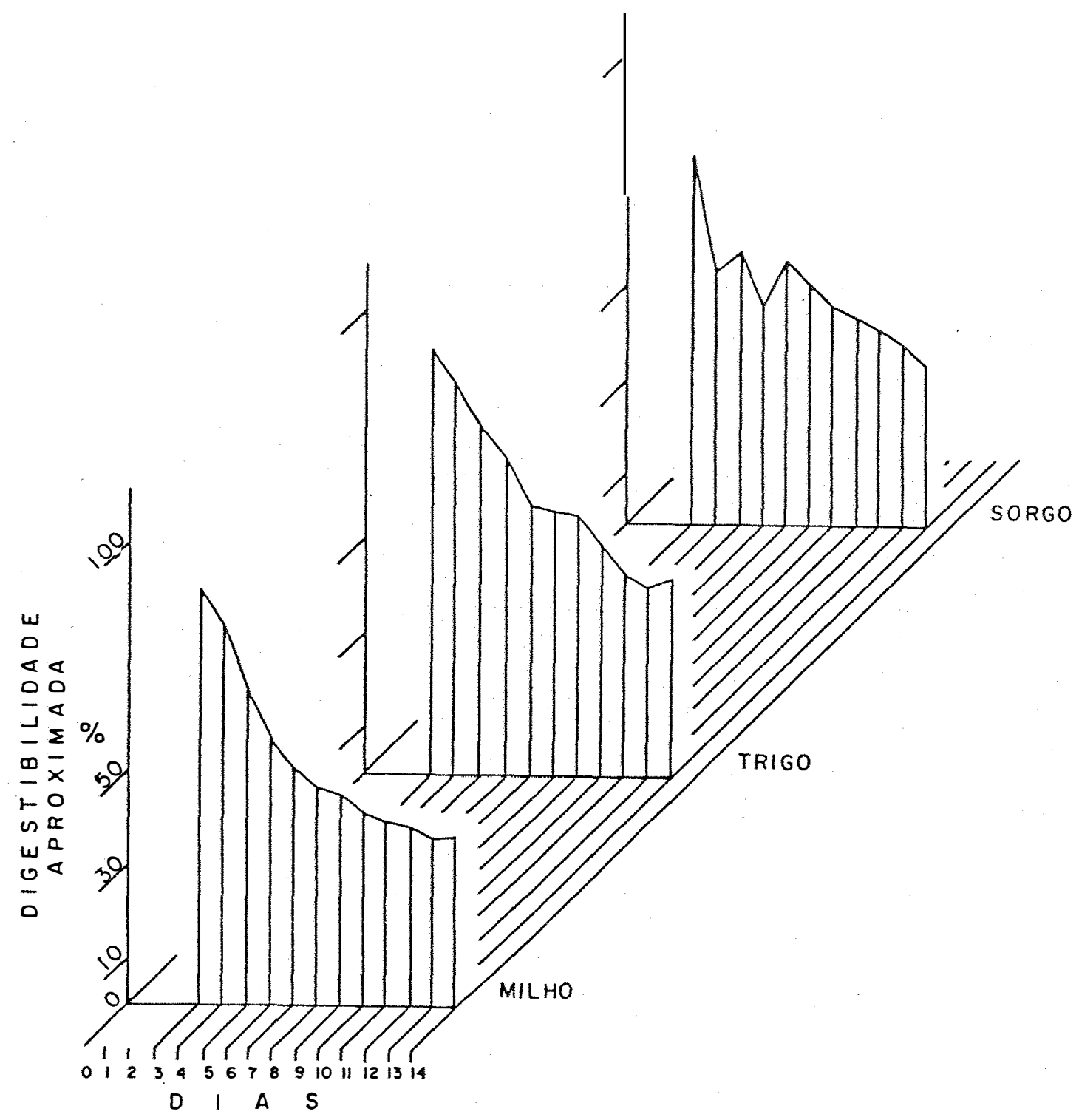

Figura 12 - Digestibilidade aproximada (AD) das folhas de milho, trigo e sorgo para as lagartas de $S$. frugiperda. Temp. $25 \pm 2^{\circ} \mathrm{C}$, UR $60 \pm 10 \%$ e fot. $14 \mathrm{~h}$. 
63.

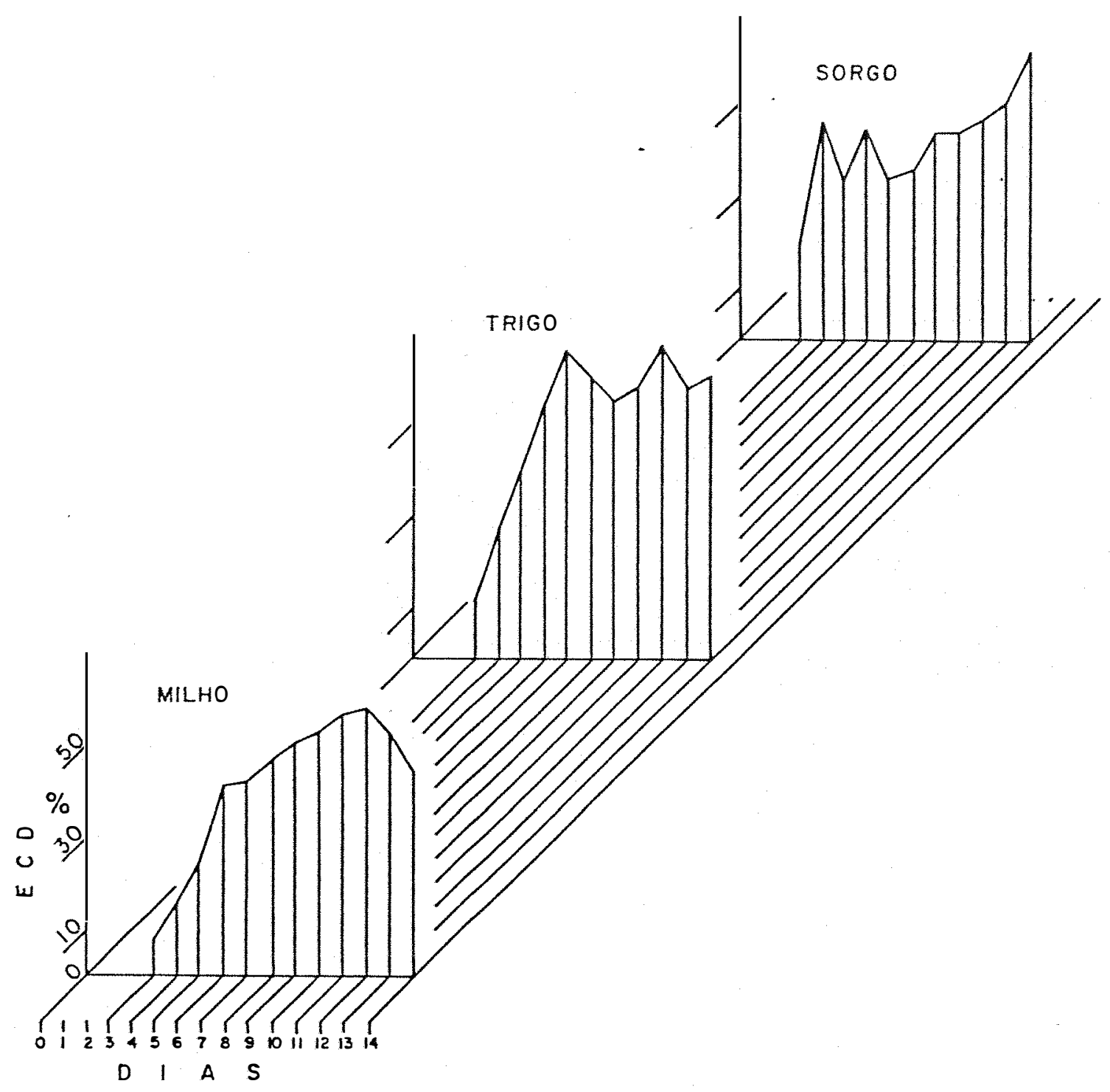

Figura 13 - Eficiência de conversão do alimento digerido (ECD) pelas lagartas de $S$. frugiperda alimentadas com folhas de milho, trigo e sorgo. Temp. $25 \pm 2^{\circ} \mathrm{C}$, UR $60 \pm 10 \%$ e fot. $14 \mathrm{~h}$. 
triente essencial. Entretanto, comparando-se as três gramíneas, provavelmente o trigo é um alimento de melhor valor nutricional que o sorgo ou o milho, porque as lagartas consumiram menos (Tabela 1, Figura 2), cresceram mais rapidamente (Tabela 3, Figura 4), digeriram melhor (Tabela 11, Figura 12) e gastaram menos em metabolismo (Tabela 12, Figura 13), embora não seja o hospedeiro preferido de $S$. frugiperda (SIFUENTES, 1967; LARA, 1979).

4.4. Consumo e utilização dos alimentos

De uma maneira geral, os índices e parâmetros estudados nesse trabalho apresentaram a mesma tendência observada para outros lepidópteros da família Noctuidae (SILVA, 1981; CARVALHO, 1981 e VENDRAMIM, 19821. Entretanto, observase que ao longo do período larval ocorreram variações dos parâmetros e índices determinados. Conforme SCRIBER e SLANSKY JR. (1981) essas variações podem ser atribuídas a inúmeros fa tores, dos quais o valor nutricional e a presença de aleloquí micos no alimento ou o tamanho e o ínstar do inseto, poderiam ter sido as causas das variações observadas no presente traba lho. Entretanto, mesmo com essas variações, as lagartas apresentaram uma performance de crescimento semelhante nos três alimentos, demonstrando que elas têm a capacidade de realizar compensações ao longo do período larval.

Assim, consicerou-se que a análise comparativa entre os diferentes hospedeiros fomeceria melhores informações sobre as qualidades do alimento para o inseto, se executada com os dados referentes ao somatório de toda a fase larval. Isso porque os dados referentes a apenas uma parte do pe ríodo de alimentação podem apresentar diferenças, que seriam compensadas até o final da fase, conduzindo a conclusões erra das.

As comparações destas médias dos parâmetros e 
indices, calculadas sobre o somatório de toda a fase larval são apresentados na Tabela 13 e Figura 14 .

\subsubsection{Parâmetros avaliados}

Observou-se que a quantidade de alimento ingerido (I) foi significativamente diferente nas três gramíneas (Tabela 13). O milho foi a mais ingerida, o sorgo a intermediária e o trigo a menos ingerida; a mesma relação foi observada para a produção de fezes (F). Porém, o ganho de biomassa (B), embora mantendo a mesma relação, foi estatisticamente di ferente apenas entre os insetos alimentados com folhas de milho e sorgo (Tabela 13).

\subsubsection{Parâmetros determinados}

A Tabela 13 mostra que os insetos que consumiram milho assimilaram (I-FL e metabolizaram (M) uma parcela maior do alimento ingerido, enquanto que não houve diferença estatística entre os insetos que consumiram trigo e sorgo. Po rêm, o peso médio $(\bar{B})$ das lagartas alimentadas com milho e com trigo não diferiu entre si e, foi maior que o das lagartas do sorgo.

\subsubsection{Indices nutricionais}

O consumo relativo (RCR) de folhas de milho foi maior que o de folhas de sorgo, que por sua vez foi maior que $O$ de folhas de trigo (Tabela 13). A taxa metabólica relativa (RMRl foi maior em S. frugiperda alimentada em milho, não havendo diferença entre as outras duas gramíneas. Entretanto, o crescimento relativo (RGRL das lagartas foi semelhan te nos três substratos.

A conversão do alimento ingerido em biomassa 
66.

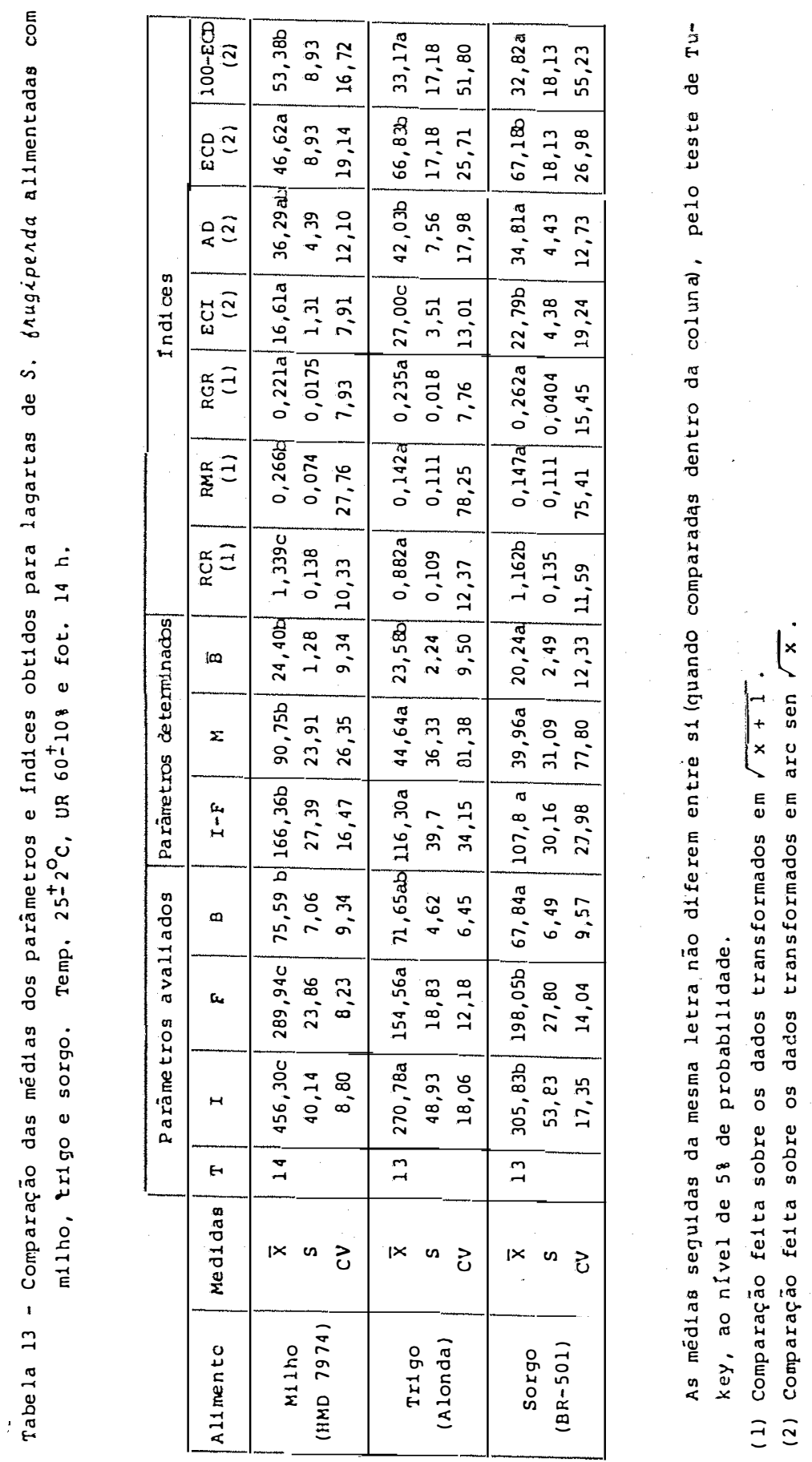


67.
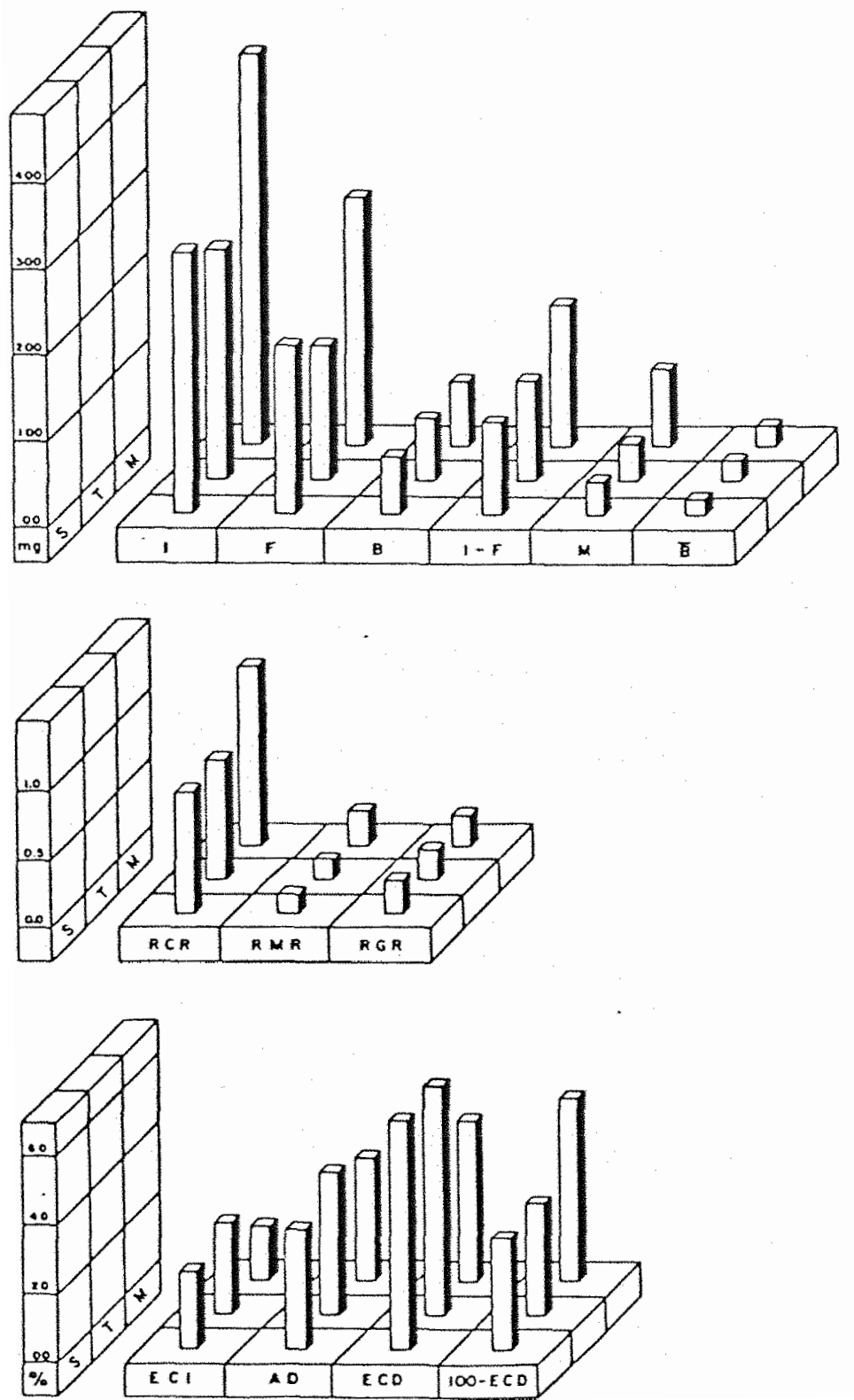

Figura 14 - Médias dos parāmetros e índices nutricionais obti dos para as lagartas de $S$. frugiperda alimentadas com milho (M), trigo (T) e sorgo (S). Temp. $25^{ \pm}$ $2^{\circ} \mathrm{C}$; UR $60 \pm 10 \% \mathrm{e}$ fot. $14 \mathrm{~h}$. 
(ECI) foi diferente entre as três gramíneas estudadas, sendo maior nas lagartas do trigo; intermediária nas do sorgo e menor naquelas lagartas que consumiram milho.

A digestibilidade aproximada (AD) do trigo foimelhor, porêm não diferiu significativamente da digestibilidade do milho a qual foi próxima a do sorgo. Entretanto, podese dizer que a digestibilidade do milho e do sorgo foram seme lhantes, e a do trigo foi um pouco maior.

As lagartas alimentadas com folhas de trigo e de sorgo converteram o alimento digerido em biomassa (ECD) com eficiência semelhante, enquanto que as que consumiram milho apresentaram uma ECD significativamente menor. Assim, O custo metabólico (100-ECD) também foi semelhante para as lagartas criadas em trigo e sorgo porém, significativamente menor do que o das criadas em milho.

\subsection{Hospedeiros}

Através do exame dos índices comparados na Tabela 13 pode-se observar que as lagartas alimentadas com folhas de trigo e de sorgo utilizaram o alimento de forma semelhante, e com melhor eficiência do que as que se alimentaram com folhas de milho.

O trigo por ter sido o alimento menos consumido, melhor digerido e ter conferido um desenvolvimento semelhante ao das lagartas alimentadas com as outras gramíneas, pode ser considerado o hospedeiro que apresentou as melhores características para a alimentação dos insetos.

o sorgo pode ser considerado um alimento de ca racterísticas inferiores âs do trigo, porém superiores às do milho, pois, embora tenha sido relativamente mais consumido que o trigo foi menos digerido, apresentando uma eficiência de conversão semelhante. Dessa forma, o maior consumo relati- 
vo do sorgo, quando comparado com o trigo, pode ser uma compensação à sua menor digestibilidade.

O milho, de acordo com o que foi discutiāo, pode ser considerado o hospedeiro que apresentou as piores características para a alimentação dos insetos, pois. foi relativamente o mais ingerido, o de maior custo metabólico e menor eficiência de conversão, embora a sua ảigestibilidade tenha sido levemente superior à do sorgo, o que pode estar rela cionado com o teor de fibra da variedade de milho utilizado. Além disso, os insetos criados em milho necessitaram de um dia de atividade alimentar a mais que os outros, para completarem a fase larval.

4.6. Consumo de ärea foli iar

O consumo de alimentos representa uma destruição da área foliar do hospedeiro. No entanto, essa área foliar será função não somente do consumo de matéria seca lou verde) mas também da relação peso seco/ārea verde apresentada pela folha das diferentes gramíneas. Essa relação varia em função da idade da planta, estado nutricional, umidade do solo, posição da folha na planta, idade âa folha, região da folha consumida pelo inseto, turgescência, espessura das folhas, etc.

A Tabela 14 mostra as relações peso seco/ área observadas para as folhas das três gramíneas estudadas. Notase que as folhas de trígo contêm mais matéria seca por unidade de área do que as folhas de sorgo, e estas contêm mais que as de milho. Assim, as diferenças observadas na ingestão dos alimentos (I) foram mais acentuadas quando expressas em termos de área foliar.

E importante salientar que, em virtude da peque na relação peso seco/área apresentada pelas folhas de milho, 
- volume de alimento que passou através do trato digestivo aas lagartas foi equivalente a aproximadamente 2 vezes o volume ingerido de folhas de sorgo e 3 vezes o volume de folhas ce trigo. Assim, em termos àe consumo de área foliar observa-se que o trigo foi a planta menos injuriada, enquanto o milho foi a mais prejudicada das três. O consumo de área foliar de sorgo registrada na presente pesquisa, se encontra no intervalo obtido por LORDELLO et al. (1980), que trabalhando com diferentes variedades de sorgo, verificaram um consumo de área foliar por $S$. frugiperda, variável de $84 \mathrm{~cm}^{2}$ até $192 \mathrm{~cm}^{2}$.

Tabela 14 - Relação peso seco/ārea foliar verde do milho, tri go e sorgo e, respectivo consumo em área foliar e peso seco (I) pelas lagartas de $S$. frugiperda. Temp, $25 \pm 2^{\circ} \mathrm{C}$, UR $60 \pm 10 \%$ e fot. $14 \mathrm{~h}$.

\begin{tabular}{lcll}
\hline Hospedeiro & $\begin{array}{r}\text { Peso seco em } \\
\mathrm{mg} / \mathrm{cm}^{2}\end{array}$ & $\begin{array}{l}\text { Alimento Inge } \\
\text { rido (I) (peso } \\
\text { seco em mg) }\end{array}$ & $\begin{array}{l}\text { Area foliar con } \\
\text { sumida em } \mathrm{cm}^{2}\end{array}$ \\
\hline $\begin{array}{c}\text { Milho } \\
\text { 'HMD 7974' }\end{array}$ & $1,89 \pm 0,36$ & $456,30 \pm 40,14 \mathrm{c}$ & $241,43 \pm 21,24 \mathrm{c}$ \\
\hline $\begin{array}{l}\text { Trigo } \\
\text { 'Alonda' }\end{array}$ & $4,00 \pm 0,52$ & $270,78 \pm 48,93 \mathrm{a}$ & $66,97 \pm 12,78 \mathrm{a}$ \\
\hline $\begin{array}{l}\text { Sorgo } \\
\text { BR-501' }\end{array}$ & $2,24 \pm 0,49$ & $305,83 \pm 58,83 \mathrm{~b}$ & $139,25 \pm 25,73 \mathrm{~b}$ \\
\hline
\end{tabular}

- Médias seguidas da mesma letra não diferem entre si, pelo teste de Tukey, ao nível de 5\% de probabilidade. 
4.7. Desenvolvimento larval

4.7.1. Duração da fase larval

o período larval foi relativamente rápido, de tal forma que as lagartas permaneceram apenas 2 dias em cada ínstar, com exceção do 6? instar que teve uma duração próxima a 5 dias (Tabela 15). A duração total do período larval foi variável entre tratamentos, sendo de 14,5 dias para insetos criados em milho e de 13,5 e 13,4, respectivamente para trigo e sorgo. Esse dia a mais das lagartas criadas em milho foi di luído entre os ínstares (Tabela 15), e pode ser explicado pela necessidade das lagartas consumirem e utilizarem alimento para obter a energia necessária à pupação, como discutido nos itens $4.3 .2,4.3 .7$ e 4.3 .9 .

Tabela 15 - Duração média (em diasl de cada um dos ínstares e de toda a fase larval de $S$. frugiperda alimentada com folhas de milho, trigo ou sorgo. Temp. $25^{ \pm}-2^{\circ} \mathrm{C}$, UR $60 \pm 10 \%$ e fot. $14 \mathrm{~h}$.

\begin{tabular}{l|cccccc|c}
\hline \multirow{2}{*}{$\begin{array}{c}\text { Trata } \\
\text { mento }\end{array}$} & I & II & III & IV & V & VI & Fase larval \\
\hline Milho & 2,0 & 2,0 & 1,9 & 1,8 & 2,1 & 4,6 & 14,5 \\
Trigo & 2,0 & 1,9 & 1,5 & 1,8 & 1,8 & 4,5 & 13,5 \\
Sorgo & 1,9 & 2,0 & 1,3 & 2,0 & 1,9 & 4,3 & 13,4 \\
\hline
\end{tabular}

4.7.2. Número de ínstares

A largura da cāpsula cefálica foi um bom parâmetro para medir o nümero de ínstares o qual não variou em - 
função do alimento ingerido, sendo constante e igual a 6 nos três substratos estudados (Tabela 16 e Figura 15). Embora o nū mero de ínstares registrado nesta pesquisa tenha sido igual ao obtido por FERRAZ (1982) à $25^{\circ} \mathrm{C}$, é possível, segundo vários autores, que este nümero varie, entre 6 e 7, dependendo da temperatura (FERRAZ, 1982) ou de cultivares (LORDELLO et al., 1980).

Tabela 16 - Largura média da cápsula cefálica, razão de crescimento e ảecremento da razão de crescimento de S. frugiperda alimentada com folhas de milho, tri go ou sorgo. Temp. $25 \pm 2^{\circ} \mathrm{C}$, UR $60 \pm 10 \%$ e fot. $14 \mathrm{~h}$.

\begin{tabular}{cccc}
\hline $\begin{array}{c}\text { Insta } \\
\text { res }\end{array}$ & $\begin{array}{c}\text { Largura da cāp- } \\
\text { sula cefálica } \\
(\mathrm{mm})\end{array}$ & $\begin{array}{c}\text { Razão de cresci- } \\
\text { mento da cāpsula } \\
\text { cefálica }\end{array}$ & $\begin{array}{c}\text { Decremento da } \\
\text { razão de cres } \\
\text { cimento }\end{array}$ \\
\hline I & 0,326 & 1,67 & 0,03 \\
II & 0,543 & 1,64 & 0,06 \\
III & 0,891 & 1,58 & 0,09 \\
IV & 1,413 & 1,49 & 0,07 \\
V & 2,109 & 1,42 & \\
VI & 3,000 & & \\
\hline
\end{tabular}

A razão de crescimento da largura da cápsula cefálica não foi constante, conforme expresso na lei de DYAR (1890) (Tabela 16L. Essa razão de crescimento mostrou-se decrescente de ínstar para ínstar, numa progressão aritmética de razão 0,03, e apenas na passagem do 5! para 0 6! ínstar es sa razão apresentou-se alterada para -0,02. Portanto, o inseto cresceu relativamente mais na passagem do 5 : para 0 6ㅇ íns tar do que nas outras ecdises. A característica decrescente da razão de crescimento da cápsula cefálica é demonstrada pela equação ce regressão linear $Y=1,755-0,065 x$, que correla 


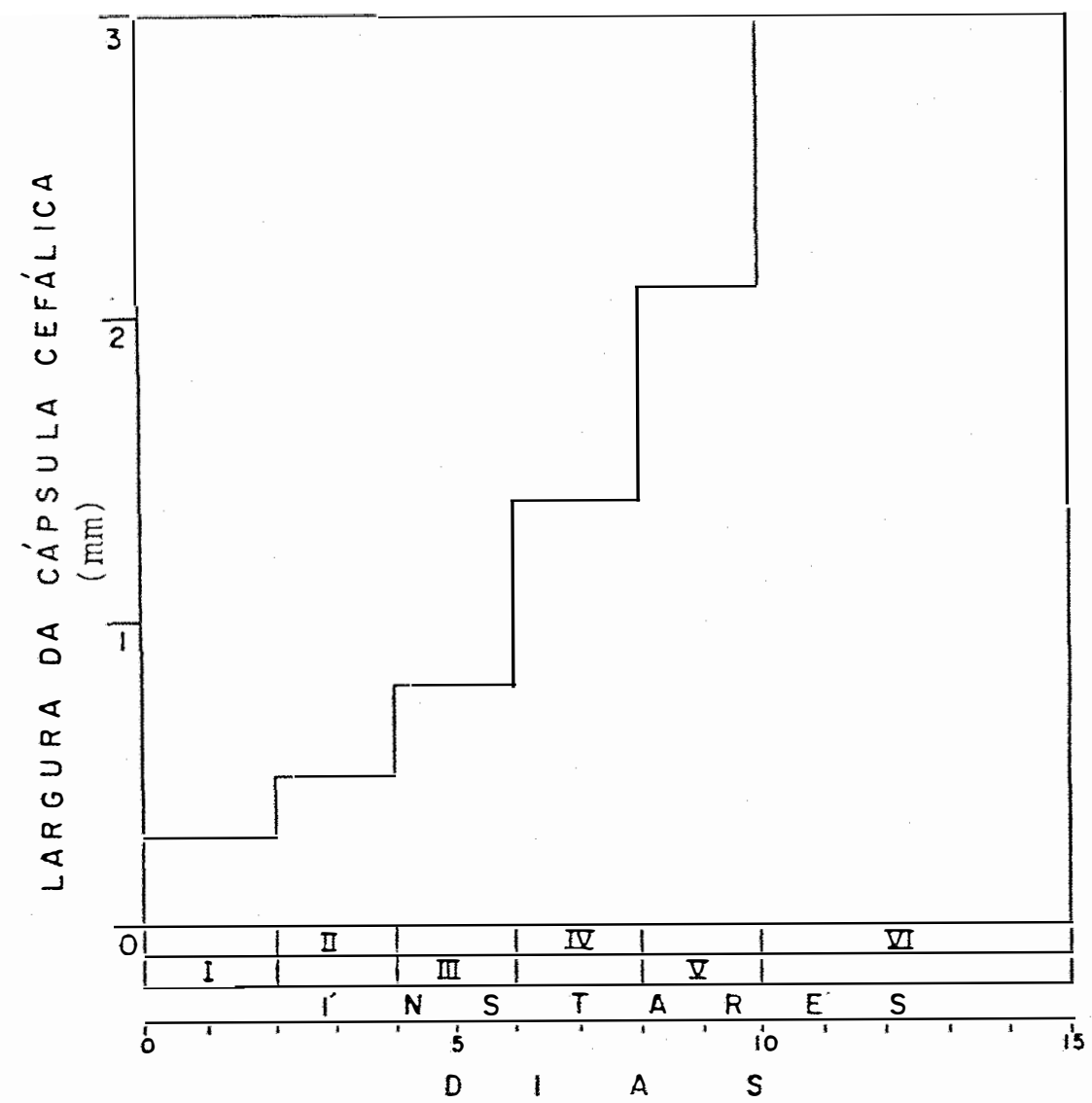

Figura 15 - Largura da cápsula cefálica, nūmero de ínstares e duração de cada ínstar larval de $S$. frugiperda criada sobre milho, trigo e sorgo. Temp. $25 \pm 2{ }^{\circ} \mathrm{C}$, UR 60-10\% e fot. $14 \mathrm{~h}$. 
ciona a razão de crescimento com o instar ( $r=0,9866 * *)$, atra vés do coeficiente angular negativo.

Porém, a razão média de crescimento da cápsula cefálica foi de 1,56, bastante próxima âquela encontrada por FERRAZ (1982) para as lagartas criadas à $25^{\circ} \mathrm{C}$ e que foi de 1,52. Esse autor também obteve uma variação na razão de crescimento da cápsula cefálica, conforme o Ínstar, variação esta irregular, mas também com uma tendência decrescente.

Embora LUCCHINI (1977) tenha obtico, para S. frugiperda, uma razão média de 1,45, houve também, nos valores obtidos por este autor, uma tendência decrescente na razão de crescimento, sendo de 1,59 na passagem do lo para o 20 ínstar e de 1,40 na passagem do 50 para o 60 ínstar. Apesar destas variações, TAYLOR (1931) considerou que isso não invalida a regra de DYAR para determinação do número de ínstares, desde que elas ocorrem em vários noctuídeos e outros lepidópteros.

A viabilidade larval foi de $100 \%$ nos três subs tratos, o que facilitou a obtenção dos dados de consumo e uti lização de alimentos.

4.8. Fase de pupa

Os dados de peso de pupas obtidos 24 horas após a pupação, e a viabilidade pupal nos diferentes hospedei ros são apresentados na Tabela 17. Observa-se que o peso das pupas cujas lagartas se alimentaram em milho foi significativamente maior do que as outras, as quais não diferiram entre si. Como foi observado apenas o peso fresco das pupas, tornase difícil a comparação com as observações da fase larval, que foram feitas em termos de matéria seca. Depenciendo do teor de ăgua das pupas, cujas lagartas consumiram milho, essa dife rença pode não ser tão significante. Porém, as pupas provenientes de lagartas alimentadas com milho apresentaram uma via- 
bilidade maior do que as outras, indicando que se encontravam em melhores condições, o que pode ser decorrência da melhor adaptação do inseto a essa graminea.

Tabela 17 - Peso de pupas e viabilidade pupal por sexo, de $S$. frugiperda criada em milho, trigo e sorgo. Temp. $25 \pm 2{ }^{\circ} \mathrm{C}$, UR $60 \pm 10 \%$ e fot. $14 \mathrm{~h}$.

\begin{tabular}{l|c|c|c|c}
\hline \multirow{2}{*}{ Substrato } & Peso pupas (mg) & \multicolumn{3}{|c}{ Viabilidade (\%) } \\
& & Macho & Fêmea & Total \\
\hline Milho 'HMD 7974' & $180,95 \pm 12,43 \mathrm{~b}$ & 79,5 & 88,9 & 83,33 \\
Trigo 'Alonal' & $158,73 \pm 16,15 \mathrm{a}$ & 70,6 & 78,8 & 76,0 \\
Sorgo 'BR-501' & $154,62 \pm 13,65 \mathrm{a}$ & 75,86 & 86,36 & 74,54 \\
\hline
\end{tabular}

Médias seguidas da. mesma letra não diferem entre si, pelo teste de Tukey, ao nível de 5\% de probabilidade.

Praticamente não houve influência da alimentação das lagartas sobre a duração do período pupal, mas houve influência sobre a viabilidade (Figura 16 e Tabela 17). E interessante observar a diferença existente entre a duração da fase pupal àos machos e das fêmeas (Figura 16). Essa diferença provocou uma defasagem na emergência de tal forma que os machos emergiam com 2 a 3 dias de atraso em relação às fêmeas. Em condições de laboratório, essa característica favoreceu a criação pois, os machos copulam logo após a emergência, porém as fêmeas só iniciam a postura 2 a 3 dias após a emergência. Não foi observado quando as fêmeas copulam, porém também, devem fazê-lo 2 a 3 dias, após a emergência.

Em condições de campo, essa defasagem na emergência dos machos e fêmeas deve ser útil para reduzir a proba bilidade de acasalamento entre indivíduos descendentes da mes ma postura. Assim, neste período as fêmeas podem voar para ou 


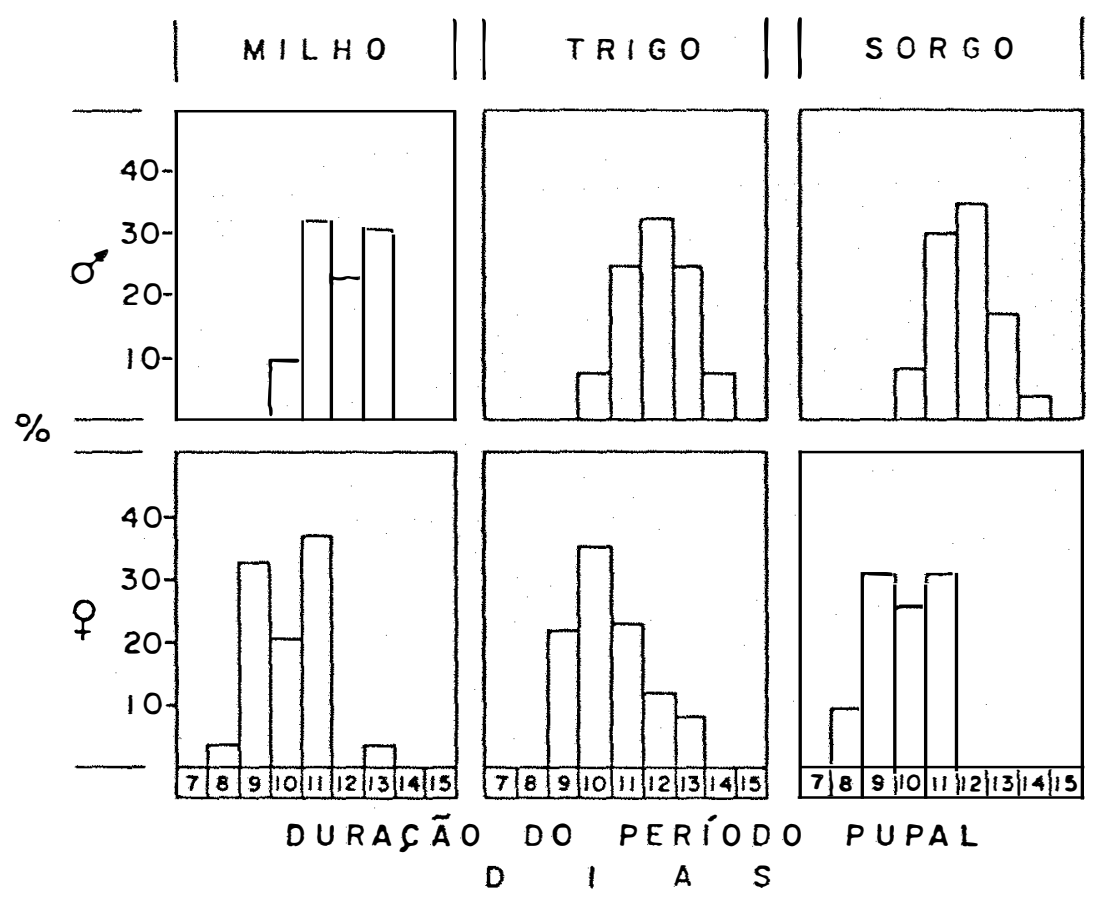

Figura 16 - Freqüéncia de duração do período pupal de machos e fêmeas de $S$. frugiperda criadas com milho, tri go e sorgo. Temp. $25 \pm 2^{\circ} \mathrm{C}$, UR $60 \pm 10 \%$ e fot. $14 \mathrm{~h}$. 
tros locais, ou, se permanecerem na área, provavelmente se acasalariam com machos provenientes de outras posturas.

As pupas, que deram origem a fêmeas, tiveram nas três gramíneas, viabilidade maior do que os machos (Tabela 17).

4.9. Influência da alimentação da fase larval sobre a sele ção hospedeira pelas lagartas descendentes.

Observou-se que lagartas provenientes de pais alimentados em folhas de milho ou trigo, durante a fase larval, apresentaram acentuada tendência a preferir folhas de mi 1ho. Por outro lado, lagartas cujos ancestrais foram alimenta dos com folhas de sorgo preferiram se alimentar de folhas de trigo (Tabela 18). Isso significa que o alimento utilizado pe lo inseto pode ter influência decisiva na escolha da planta hospedeira pelos seus descendentes.

Observando-se as porcentagens de fixação e fuga, constata-se que $69 \%$ das lagartas descendentes do grupo alimentado com sorgo, abandonaram a arena de teste. Essa fuga representou morte por inanição, pois não havia outro alimento disponível nas proximidades do experimento, o que pode ser atribuído à incapacidade de reconhecer seu hospedeiro pelo odor ou mesmo pela "mordida" de prova.

Durante a criação das lagartas, observou-se que quando alimentadas com sorgo elas apresentavam a característica do canibalismo desde os primeiros ínstares. Por outro lado, aquelas alimentadas com folhas de trigo somente apresen taram hâbito canibal no 60 Instar. As lagartas criadas sobre milho apresentaram um comportamento intermediário, ora apresentando canibalismo ora não, com essa caracterIstica intensi ficada no 69 Instar.

Ao que parece esse padrão de comportamento - 


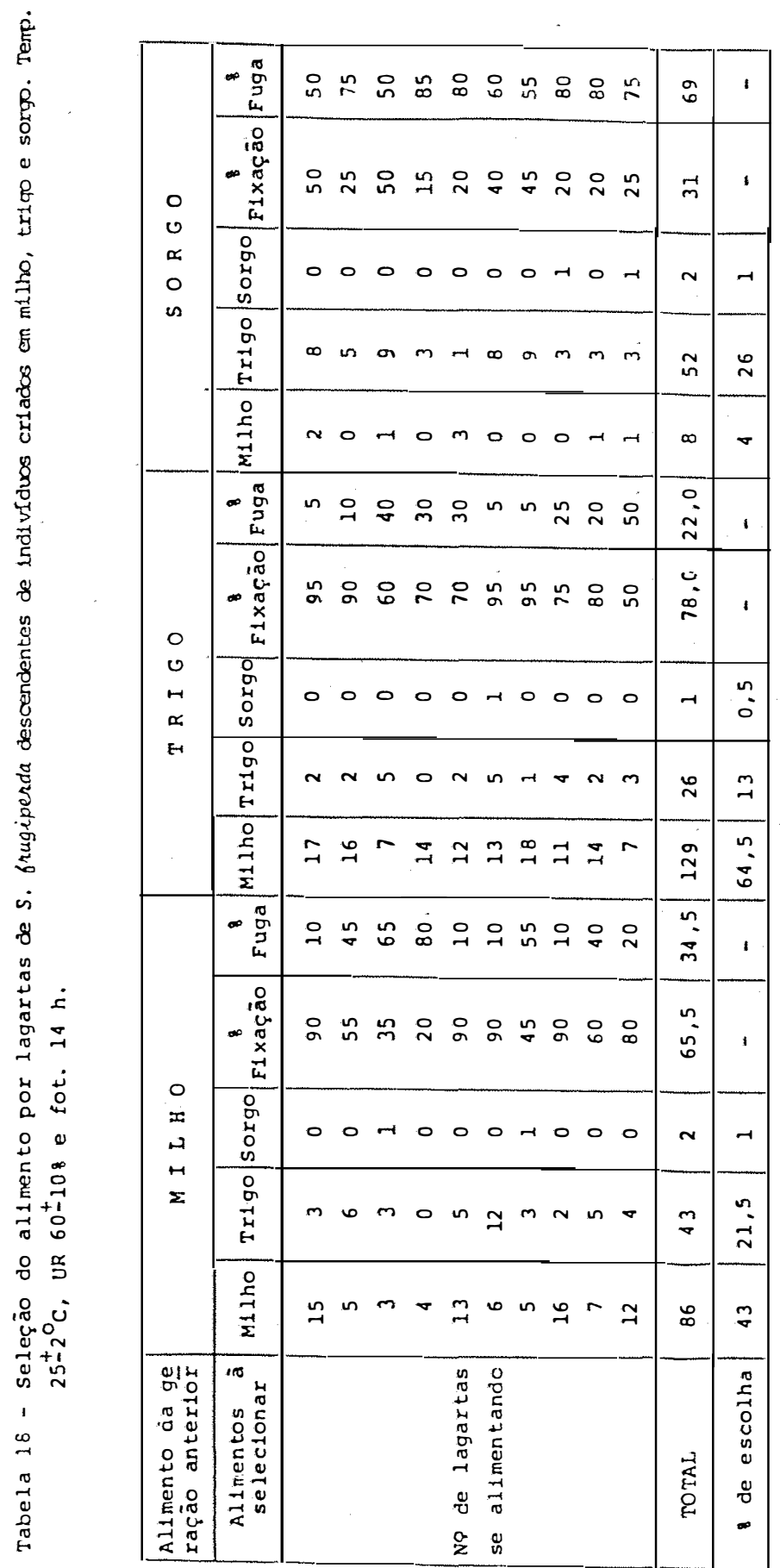


foi transmitido para a geração seguinte, o que pode ser de duzido das porcentagens de fuga. A descendência das lagartas criadas em trigo apresentou a menor taxa de fuga, e, consequien temente, uma seleção e aceitação mais rápida do hospedeiro. Já as lagartas alimentadas com sorgo apresentaram uma taxa de fuga 3 vezes maior, demonstrando dificuldade de seleção e acei tação do hospedeiro.

E provāvel que as lagartas de $S$. frugiperda es tejam geneticamente adaptadas a preferir o milho como principal hospedeiro. Entretanto, os resultados obtidos (Tabela 18) sugerem que a preferência alimentar das lagartas recém-eclodi das, sofrem a interferência de alguma informação transmitida através do citoplasma materno. Porém, a confirmação dessa hipótese exige um estudo exaustivo sobre a preferência hospedei ra.

Provavelmente, a preferência das lagartas de S. frugiperda pelas folhas do milho é o resultado de um longo processo evolutivo, no qual elas devem ter desenvolvido essa preferência exatamente para o hospedeiro menos favorável (entre os très estudados).

4.10. Influência da alimentação da fase larval sobre a seleção hospedeira pelos adultos

o número e a porcentagem de ovos colocados pelos adultos de $S$. frugiperda em milho, trigo e sorgo, quando mantidos em dois tipos de gaiolas, são mostrados na Tabela 19. Constatou-se que nas gaiolas pequenas as mariposas colocaram um número razoável de ovos sobre as plantas. Nas gaiolas gran des as posturas foram feitas, praticamente, apenas nas paredes das gaiolas, sendo que as plantas foram evitadas. Assim, embora tenham apresentado uma certa tendēncia a ovipositar mais em milho nas gaiolas pequenas (Tabela 19), isso não pode ser 


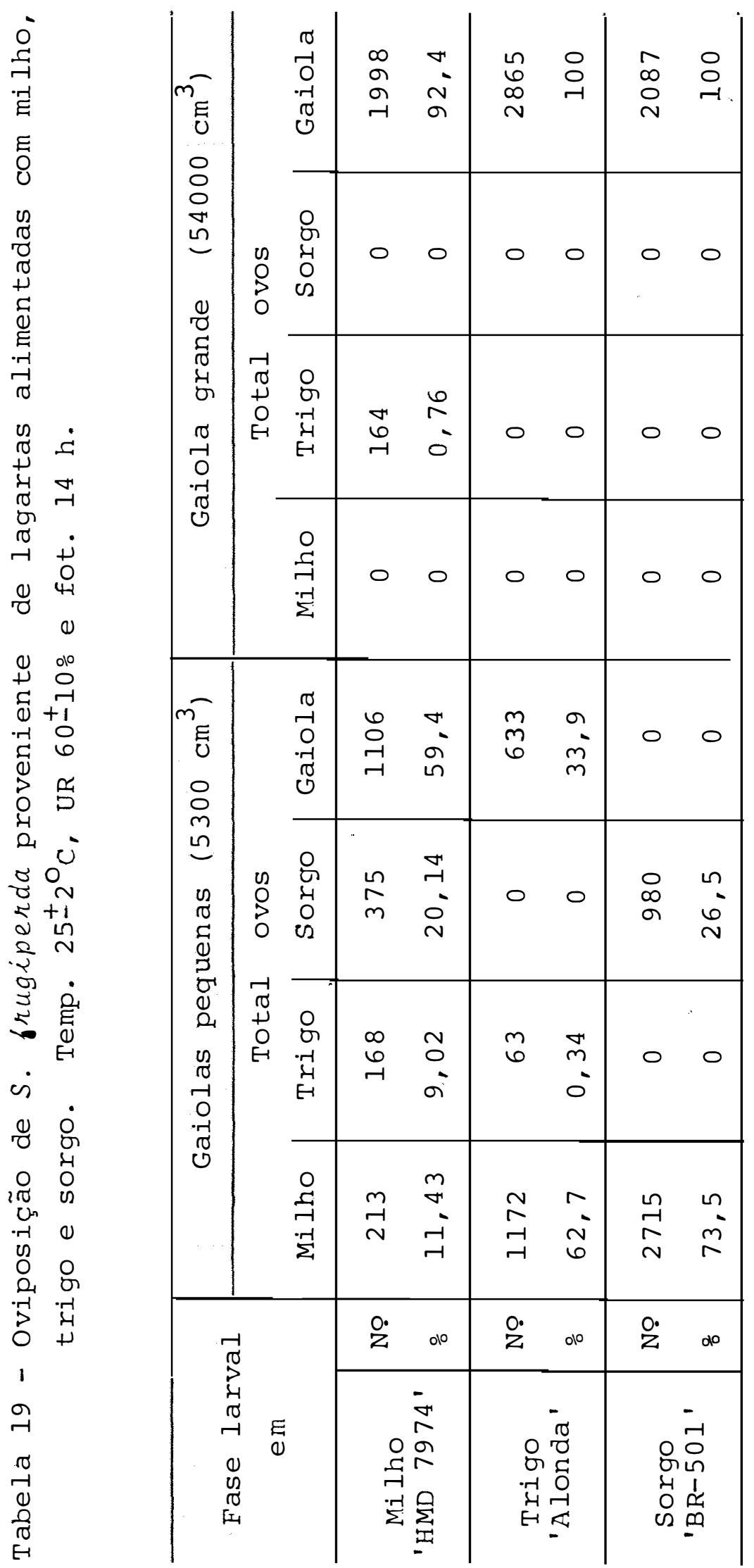


atribuído à uma preferência de oviposição, mas sim ao fato das folhas serem mais facilmenté encontradas devido à sua maior largura.

Portanto, no presente experimento, as mariposas fizeram posturas aleatórias, sem manifestar uma preferência definida. LUNGBILL (1928) também relatou que as fêmeas de $S$. frugiperda realizam a postura de forma indiscriminada. Por outro lado, VALERIO (1978), estudando a preferência de oviposição desse inseto em diferentes variedades de cynodon dactylon (L.), observou que as fêmeas ovipositaram mais em plantas de folhas mais largas. Como no presente trabalho foram utilizadas plantas com 15 dias de idade, quando ainda apresentavam as folhas relativamente estreitas, é possível que não estives sem num estado fenológico adequado para a seleção por $S$. frugiperda.

Entretanto, sem se conhecer claramente o compor tamento de oviposição desse inseto, é difícil realizar um tes te de preferência. Dessa forma, seria necessário um estudo mais específico e profundo sobre a seleção hospedeira pelos adultos de $S$. frugiperda, o que demandaria conhecer a influên cia da forma, tamanho e material utilizado na construção das gaiolas de teste, assim como da forma, tamanho, cor, odor e textura das folhas das plantas sobre o comportamento de ovipo sição. Portanto, não foi possível obter nesse experimento ne nhuma informação segura sobre a seleção hospedeira, tomandose por base a oviposição de $S$. frugiperda. 
82.

5. CONCLUSOES

Os resultados obtidos no presente trabalho per mitem concluir:

- o trigo é o hospedeiro que apresenta as melhores características nutricionais;

- O milho é o hospedeiro que mais afeta a fisiologia e o comportamento alimentar das lagartas de $S$, frugiper da, sendo o trigo o que afeta menos;

- o consumo de área foliar é maior no milho;

- As lagartas de $S$. frugiperda apresentam a capa cidade de compensar as dificuldades de utilização encontradas nos diferentes hospedeiros e manter a performance de desenvol vimento;

- o alimento ingeriao não influi. no nümero de Ínstares;

- A razão àe crescimento da cápsula cefálica decresce numa progressão aritmética de razão 0,03;

- O alimento ingerido afeta a viabilidade pupal;

- O ciclo dos insetos criados em milho é ligei ramente maior do que o dos criaāos nas outras gramíneas;

- Independentemente do alimento, a emergência 
das fêmeas é anterior a dos machos;

- o alimento afeta o comportamento das lagartas em termos de agressividade;

- O alimento ingerido afeta a preferência alimentar das lagartas da geração seguinte;

- Não foi possível avaliar a preferência para oviposição no estado fenológico estudado. 
84

6. LITERATURA CITADA

BAILEY, D.L. e H.L. CHADA, 1968. Effects of natural (sorghum) and artificial (wheat germ) diets on development of the corn earworm, fall armyworm, and southwestern corn bo rer. Journal of Economic Entomology, Baltimore, 61(1):257260 .

BARFIELD, C.S.; E.R. MITCHELL e S.L. POE, 1978. A temperature-dependent model for fall armyworm development. Annals of the Entomological Society of America, Columbus, $11(1): 70-74$.

BECK, S.D., 1965. Resistance of plants to insects. Annual Review of Entomology, California, 10:207-32.

BERTELS, A. e M.A.B. ROCHA, 1950. Observações preliminares sobre pragas do milho. AGROS, Pelotas, $\underline{3}(3): 160-183$.

BHAT, N.S. e A.K. BHATTACHARYA, 1978. Consumption and utilization of soybean by Spodoptera litura (Fabricius) at different temperatures. Indian Journal of Entomology, New Delhi, $\underline{40}(1): 16-25$. 
BHATTACHARYA, A.K. e G.B. PANT, 1976. Studies on the host plant relationships: consumption and utilization profile in insects. Proceedings of Natural Academy of Science, India, $46(\mathrm{~B}), \mathrm{I} \& \mathrm{II}, 1976$.

BOWLING, C.C., 1967. Rearing of two lepidopterous pests of rice on a common artificial diet. Journal of Economic Entomology, Baltimore, 60:1215-1216.

BRUES, C.T., 1946. Insect dietary. Cambridge, Mass., Harvard University Press, $466 \mathrm{pp}$.

BURTON, R.L. e W.D. PERKINS, 1972. WSB, a new laboratory diet for the corn earworm and the fall armyworm. Journal of Economic Entomology, Baltimore, 65:385-386.

BUTT, B.A. e E. CANTU, 1962. Sex determination of lepidopterous pupae. ARS, United States Department of Agriculture, Washington, no 33-75, 7p.

CARVALHO, R.P.I., 1970. Danos, flutuação da população, controle e comportamento de spodoptera frugiperda (J.E. Smith, 1797) e susceptibilidade de diferentes genótipos de milho, em condições de campo. Piracicaba, ESALQ/USP, 170p. (Tese de Doutoramento).

CARVALHO, S.M. de., 1981. Biologia e nutrição guantitativa de Alabama argillacea (Huebner, 1818) (Lepidoptera, Noctuidae) em três cultivares de algodoeiro. Piracicaba, ESALQ/ USP, 97p. (Dissertação de Mestradol.

CHITTENDEN, F.H., 1901. Fall armyworm and variegateò cutworm. ARS, United States Department of Agriculture, Washington, 29:1-64.

COMBS, Jr., R.T.C. e J.R. VALERIO, 1980. Biology of the fall 
armyworm on four varieties of bermudagrass when held at constant temperatures. Environmental Entomology, College Park, $\underline{9}(4): 393-395$.

CRUZ, I. e F.T. TURPIN, 1982. Efeito da spodoptera frugiperda em diferentes estágios de crescimento da cultura do mi1ho. Pesquisa Agropecuāria Brasileira, Brasília, 17 (3):355359.

DETHIER, V.G., 1947. Chemical insect attractants and repellents. Philadelphia, Blakiston Co., $289 \mathrm{pp}$.

DEW, J.A., 1913. Fall armyworm Laphygma frugiperda (S.\& A.). Journal of Economic Entomology, Baltimore, 6 (4):36l-366.

DUODU, X.A. e F.F. BINEY, 1981. Growth, food consumption and food utilization of Spodoptera littoralis (Boisduval) (Lepi doptera-Noctuidael on four food-plants. "Bulletin of Entomological Research, Iondon, Jl:655-662.

DYAR, H.G., 1890. The number of molts of lepidopterous larvae. Psyche, Cambridge, $\underline{5}: 420-422$.

EDWARDS, P.J. e S.D. WRATTEN, 1980. Ecology of Insect-Plant Interations. London, Edward Arnold Publishers, 71 pp.

ESCALANTE, J.A., 1974. Contribución al conocimiento de la Biologia de Heliothis zea y spodoptera frugiperda, en el Cusco. Revista Peruana de Entomologia, Lima, 17(1):121-122.

ESTRADA, R.F.A., 1960. Lista preliminar de insetos associados al maiz en Nicaragua. Turrialba, 10(2):68 73 . 
ETCHEVERRY, M. , 1957. Laphygma frugiperda (Abbot \& Smith) in Chile (Lepidoptera-Noctuidae). Revista Chilena de Entomologia, Santiago, 5: 183-192.

FENTON, F.A., 1952. Field crop insects. New York, MacMillan, $405 \mathrm{p}$.

FERRAZ, M.C.V., 1982. Determinação das exigências térmicas de Spodoptera frugiperda (J.E. Smith, 1797) (Lepidoptera, Noctuidae) em cultura de milho. Piracicaba, ESALQ/USP, 75 p. (Dissertação de Mestrado).

FONSECA, J.P., 1943. Lagartas nocivas às gramíneas. O Biológico, são paulo, 9 (12):411-414.

FRAENKEL, G., 1953. Nutritional value of green plants for in sects. In: Transaction of the 9 th International Congress of Entomology. Amsterdam, V.2, p.90-100.

_ 1959. The raison d'être of secondary plant substances. Science, Lancaster, 129:1466-1470.

HYNES, H.B.N., 1942. Lepidopterous pests of maize in Trinidad. Tropical Agriculture, Trinidad, 19(10):194-202.

JONES, C.G.; P.M. HOGGARD e M.S. BLUM, 1981. Pattern and process in insect feeding behaviour: A quantitative analysis of the mexican bean beetle, Epilachna varivestis. Entomologia experimentalis et applicata, Amsterdam, 30:254264 .

KASTEN, Jr., P.; A.A.C.M. PRECETTI e J.R.P. PARRA, 1978. Dados biológicos comparativos de spodoptera frugiperda (J.E. Smith, 1797) em duas dietas artificiais e substrato natu- 
ral. Revista de Agricultura, Piracicaba, $53(1-2): 68-78$.

KOGAN, M., 1975. Plant resistance in pest management. In: METCALF, R.L. e LUCKMANN, W.H. ed. Introduction to insect pest management, New York, John Wiley \& Sons, 1975. p.103146.

- - 1976. The role of chemical factors in insect/plant relationships. In: Proceedings of $\mathrm{XV}$ International Congress of Entomology, Washington D.C., August 19-27. p. 211-227.

e J.R.P. PARRA, 1981. Techniques and applications of mesurements of consumption and utilization of food by phytophagous insects. In: BHASKARAN, G.; FRIEDMAN, S.; RODRIGUEZ, J.G., ed. Current topics in insect endocrinology, and nutrition. New York, Plenum Publishing Corporation, $p$. $337-352$.

LARA, F.M., 1979. Princípios de resistência de plantas a insetos. Piracicaba, Livroceres, 207 pp.

LEIDERMAN, L. e H.F.G. SAUER, 1953. A lagarta dos milharais Laphygma frugiperda (Abbot \& Smith, 1797). O Biológico, são paulo, $19(6): 105-113$.

LORDELLO, A.L.L.; F.M. LARA; J.R.P. PARRA, 1980. Preferência para alimentação de spodoptera frugiperda (J.E. Smith, 1797) (Lepidoptera-Noctuidael em sorgo, em condições de laboratório. Anais da Sociedade Entomológica do Brasil, Jaboticabal, 9 (2):219-241.

LUCCHINI, F., 1977. Biologia de Spodoptera frugiperda (Smith \&Abbot, 17972 (Lepidoptera-Noctuiảal. Níveis àe prejuízos e avaliação toxicolögica de inseticidas para o seu com- 
bate em milho. Curitiba, Universidade Federal do Paraná. $114 \mathrm{p}$. (Dissertação de Mestrado).

LUNGIBILL, P. , 1928. The fall armyworm. Technical Bulletin. United States Department of Agriculture, Washington, 34:191.

MALAUSA, J.C. e D. MARIVAL, 1981. Étude de la dynamique des populations des chenilles de spodoptera frugiperda Abbot \& Smith et d'Heliothis zea, Boddie (Lepidoptera:Noctuidae) sur des varietés de mais en Guadeloupe (Antilles-Françaises). Agronomie, Paris, $1(8): 701-706$.

MANUWOTO, S. e J.M. SCRIBER, 1982. Consumption and utilization of three maize genotypes by the southern armyworm. Journal of Economic Entomology, Baltimore, 75(2):163-67.

MARQUEZ, S.A.; J. de la F. VILLARREAL; D.E. SCHALLENMUELLER e J.M. VEILLARD, 1963-1964. Estudios biológicos del gusano cogollero. Informe Anual de Investigacion, Monterrey, $\underline{9}$ : 27-32.

MENSCHOY, A.B., 1956. Pragas do milho, métodos de defesa. Boletim Técnico do Instituto Agronômico do Sul, Pelotas, no $16,18 \mathrm{p}$.

MERTEL, P.; M. HUDON e C. RITCHOT, 1980. Etat des insectes nuisibles dans certaines cultures du sud-ouest du Québec en 19.79. Annals of the Entomological Society of Québec, Québec, $25: 190-194$.

METCALF, C.L. e W.P. FLINT, 1965. Insectos destructivos y insectos utiles, sus costumbres e su control. 4 ed, México, Continental, $630 \mathrm{p}$. 
PAINTER, R.H. , 1958. Resistance of plants to insects. Annual Review of Entomology, Palo Alto, 3:267.300.

PARRA, J.R.P., 1979. Biologia dos insetos. Piracicaba, ESALQ, 383p. (mimeografado).

RANDOLPH, N.M. e P.M. WAGNER, 19.66. Biology and control of the fall armyworm. Texas Agricultural Experiment Station Report, Texas, no 2431. 6p.

REESE, J.C., 1977. The effects of plant biochemicals on insect growth and nutritional physiology. In: P.A. Hedin ed. Host Plant Resistance to Pests, ACS Symposium Series 62, American Chemical Society, washington, D.C.

REVELO, M.A. e E.S. RAUN, 1964. Rearing the fall armyworm un der greenhouse conditions. Journal of Economic Entomology. Baltimore, 57 (6): 1000.

SCHOONHOVEN, L.M. e J. MEERMAN, 1978. Metabolic cost of chan ges in äiet and neutralization of allelochemics. Entomologia experimeritalis et applicata, Amsterdam, 24:489-493.

Entomologia experimentalis et applicata, Amsterdam, 31:5769.

SCRIBER, J.M. e F. SLANSKY JR., 1981, The nutritional Ecology of imature insects. Annual Review of Entomology, Palo Alto, 26: $183-211$.

of southern armyworm larvae as a function of plant species consumed in earlier instars. Entomologia experimentalis et 
applicata, Amsterdam, 31:359-369.

SIFUENTES, J.A., 1967. Oviposición de palomillas del cogolle ro y daño de las larvas en plantulas de maiz y sorgo, en in vernadero. Agricultura Técnica en México, México, 2 (7): 311-314.

SILVA, A.G. d'A. ; C.R. GONÇALVES; D.M. GALVR̃O; A.J.L. GONÇALVES; J. GOMES; M.N. SILVA e L. SIMONI, 1968. Quarto catálogo dos insetos que vivem nas plantas do Brasil, seus parasitos e predadores. Rio de Janeiro, Ministério da Agricultura. pte. $2, \mathrm{v} .1$.

SILVA, R.F.P. da, 1981. Aspectos biológicos e nutricão de Anticarsia gematalis Huebner, 1818 (Lepidoptera-Noctuidae) em meios natural e artificial e influência da temperatura e fotoperíodo no seu desenvolvimento. Piracicaba, ESALQ/USP , 130p. (Tese de Doutorado).

SLANSKY JR, F. e J,M. SCRIBER, 1982. Selected bibliography and summary of quantitative food utilization by imature in sects. Bulletin of Entomological Society of America, washington, $28(1): 43-55$.

SMITH, B.R.C., 192l. Observations on the fall armyworm (Laphygma frugiperda Smith \& Abbotl and some control experiments. Journal of Economic Entomology, Baltimore, 14:300308 .

SOO HOO, C.F. e G. FRAENKEL, 1966a. The selection of food plants in a polyphagous insect, Prodenia eridania (Craemer). Journal of Insect Physiology, London, 12:639-709.

- _ 1966b. The consumption, digestion, and utilization of food plants by a polyphagous in- 
sect, Prodenia eridania (Craemer). Journal of Insect Physioloy, London, 12:711-730.

SPARKS, A.N., 1979. A review of the biology of the fall army worm. Florida Entomologist, Gainesville, $\underline{62}(2): 82-87$.

TAYLOR, R.L., 1931. On "Dyar's Rule" andits application to sawfly larvae. Annals Entomological Society of America, Columbus, $34: 451-466$.

VALERIO, J.R., 1978. Ovipositional preference and biology studies of the fall armwworm, spodoptera frugiperda (J.E. Smith) utilizing four varieties of bermudagrass, Cynodon dactylon (L.) Pers. Mississippi, Mississippi state Universi ty. 75p. (Master of Science Thesis).

VELEZ, C.M. e J.A.A. SIFUENTES, 1967. El gusano cogollero del maiz. Su combate con insecticidas granulaảos en valle de Apatzingan, Mich. Agricultura Técnica en México, Méxi$\mathrm{co}, \underline{2}(7): 315-317$.

VENDRAMIM, J.D., 1982. Influência de cultivares de couve (Brassica oleracea L. var. acephalal na biologia e nutrição de Agrotis subterranea (Fabricius, 1794l (Lepidoptera - Noctuidae). Piracicaba, ESALQ/ÜSP, 112 p. (Tese de Doutorado).

WALDBAUER, G.P., 1964. The consumption, digestion and utilization of solanaceous and non-solanaceous plants by larvae of the tobacco hormworm, protoparce sexta (Johan.) (Lepidop tera-sphingidael. Entomologia experimentalis et applicata, Amsterdam, I: 253-269.

WALDBAUER, G.P., 1968. The consumption and utilization of food by insects. Advances in Insect Physiology, New York, 
5: 229-88.

WHITTAKER, R.H., 1970. Chemical Ecology. Sondheimer, E. e Simeone, J.B. Eds, Academic Press, New York, pp. 43-70. 